\title{
AVALIAÇÃO DO IMPACTO DOS PROGRAMAS DE BOLSA ESCOLA NO TRABALHO INFANTIL NO BRASIL
}

\author{
ANDREA RODRIGUES FERRO
}

Dissertação apresentada à Escola Superior de Agricultura "Luiz de Queiroz", Universidade de São Paulo, para obtenção do Título de Mestre em Ciências, Área de Concentração: Economia Aplicada.

P I R A C I C A B A

Estado de São Paulo - Brasil

Novembro - 2003 


\section{AVALIAÇÃO DO IMPACTO DOS PROGRAMAS DE BOLSA ESCOLA NO TRABALHO INFANTIL NO BRASIL}

\section{ANDREa Rodrigues Ferro}

Bacharel em Ciências Econômicas

Orientador: Profa. Dra. ANA LÚCIA KASSOUF

Dissertação apresentada à Escola Superior de Agricultura "Luiz de Queiroz”, Universidade de São Paulo, para obtenção do Título de Mestre em Ciências, Área de Concentração: Economia Aplicada.

P I R A C I C A B A

Estado de São Paulo - Brasil

Novembro - 2003 


\title{
Dados Internacionais de Catalogação na Publicação (CIP)
} DIVISÃO DE BIBLIOTECA E DOCUMENTAÇÃO - ESALQ/USP

\author{
Ferro, A ndrea Rodrigues \\ A valiação do impacto dos programas de bolsa escola no trabalho infantil no \\ Brasil/ A ndrea Rodrigues Ferro. - - Piracicaba, 2003. \\ $92 \mathrm{p}$. \\ Dissertação (mestrado) - - Escola Superior de Agricultura Luiz de Queiroz, \\ 2003. \\ Bibliografia. \\ 1. Bolsa-escola 2. Política social 3. Trabalho de menor I. Título
}

CDD 331.38

"Permitida a cópia total ou parcial deste documento, desde que citada a fonte - O autor" 


\section{AGRADECIMENTOS}

Este trabalho é fruto de um esforço pessoal para a conquista de objetivos de vida. Mas também é fruto do apoio de muitas pessoas, que de alguma forma contribuíram para o sucesso desta tarefa. Pessoas que se dispuseram a ler, ouvir e criticar as versões anteriores; que fazem de tudo para que os dias e as coisas sejam menos emperrados, mais transparentes; que acreditaram nessa coisa obscura chamada potencial e incentivaram meu caminho até aqui. É também fruto do coleguismo, da amizade e do apoio de pessoas que contribuíram para que esta conquista fosse alcançada pelo simples fato de existirem.

Algumas dessas pessoas tiveram destaque nesta trajetória - sejam professores, amigos ou família: Rudinei Toneto Jr., Amaury P. Gremaud, Reynaldo Fernandes, Ana Lúcia Kassouf, Alexandre L. M. Barros, Rodolfo Hoffmann, Mirian R. P. Bacchi e Ricardo Shirota; Andresa C. Biason, Claudia D. Mattos, Renata R. Silva, Nara Rosseti, Guilherme R. C. Moreira e Luiz Cláudio M. Monteiro; Maielli, Heloísa Maria, Fábio Henrique, Davi Rogério, Silvio Massaro, Elisson Andrade, André Silveira, Alexandre Nunes, Thelma e Louise; Luiz Antonio, Nilcéia, Daniela, Fabrício, Juliana, José Walter, Nelci, Muriel, Aparecido e Cecília.

A todas essas pessoas, agradeço sinceramente.

Agradeço especialmente ao Alexandre Chibebe Nicolella, por participar neste período de toda a sorte de questionamentos, crises e dúvidas - intelectuais, teóricas, metodológicas, existenciais e hormonais - sempre com tranqüilidade, bom humor e companheirismo. 


\section{SUMÁRIO}

Página

LISTA DE FIGURAS............................................................................ vi

LISTA DE SIGLAS........................................................................... viii

LISTA DE TABELAS.......................................................................... ix

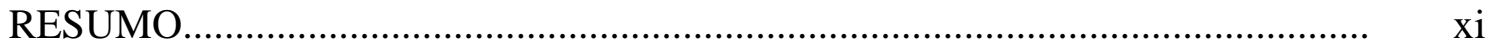

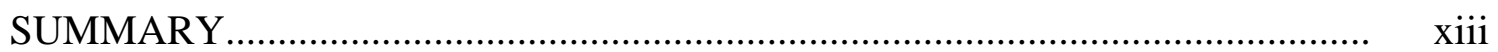

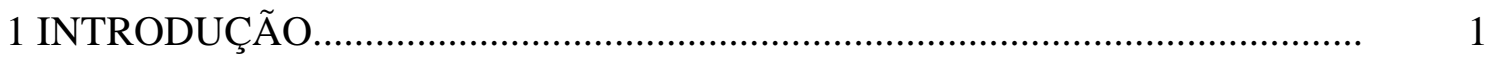

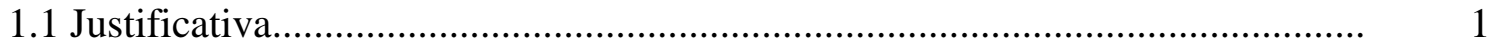

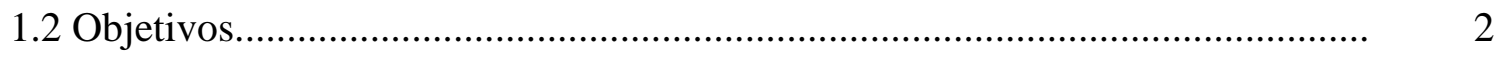

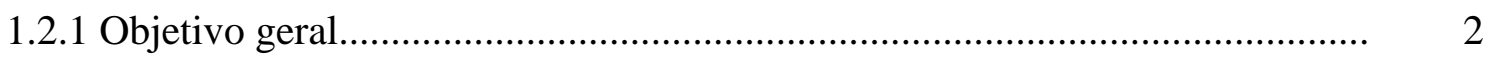

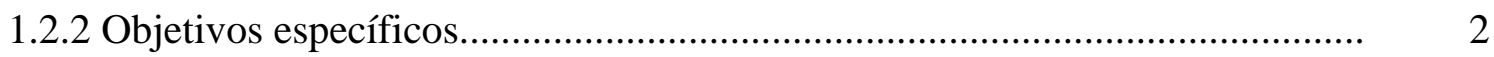

1.3 Estrutura do Trabalho............................................................................ 3

2 REVISÃO BIBLIOGRÁFICA.................................................................. 4

2.1 Contextualização: o trabalho de crianças e adolescentes...................................

2.2 As políticas de combate e erradicação do trabalho infanto-juvenil.................... 21

2.2.1 Focalização versus universalização de programas sociais............................... 23

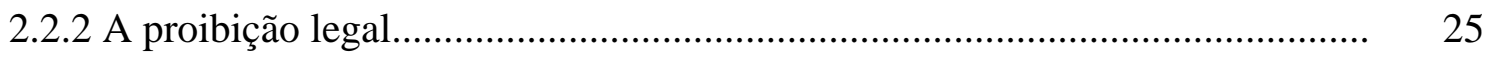

2.2.3 Políticas de transferência de renda e incentivo à educação............................ 27

2.3 Avaliação de políticas sociais..................................................................... 36

2.3.1 Avaliação de programas de renda mínima vinculada à educação................... 39

3 MATERIAL E MÉTODOS................................................................. 48

3.1 Um modelo econômico de determinação do trabalho infantil........................... 48

$3.2 \mathrm{O}$ modelo econométrico utilizado............................................................ 52

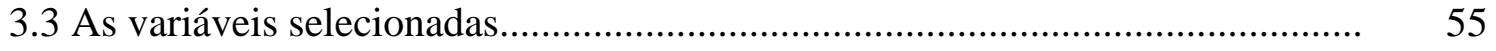




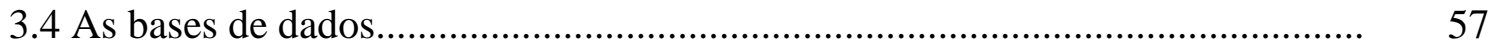

4 RESULTADOS E DISCUSSÃO................................................................ 60

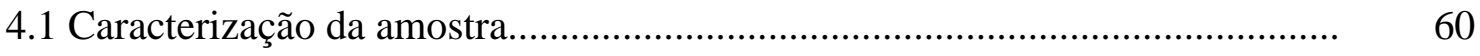

4.2 Análise econométrica..............................................................................

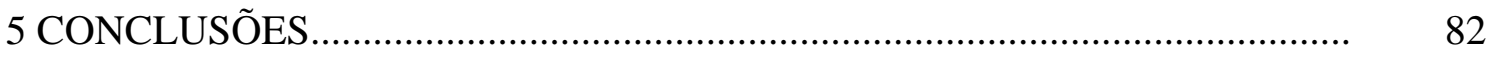

REFERÊNCIAS BIBLIOGRÁFICAS........................................................... 86

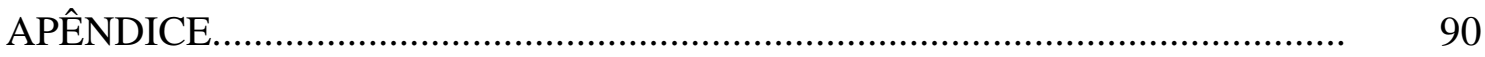




\section{LISTA DE FIGURAS}

Página

1 Participação dos grupos de idade em que começou a trabalhar segundo grupos de idade da população adulta. Brasil, 2001

2 Percentual de crianças de 5 a 15 anos economicamente ativos no Brasil, segundo grupos de idade. 2001

3 Crianças inscritas em programas sociais de incentivo à educação, segundo ocupação e grupos de idade. Brasil, 2001

4 Rendimento médio do trabalho principal e número médio de anos de estudo da população adulta segundo o grupo de idade em que começou a trabalhar. Brasil, 2001.

5 Percentual de crianças de 6 a 15 anos que só estudam, estudam e trabalham, só trabalham ou não estudam nem trabalham, segundo grupos de idade.

Brasil, 2001.

6 Grupos de ocupação das crianças de 6 a 15 anos de idade segundo grupos de idade. Brasil, 2001.

7 Média da renda per capita familiar mensal, em reais, sem a renda da criança, de crianças de 6 a 15 anos que só estudam, estudam e trabalham, só trabalham ou não estudam nem trabalham, segundo grupos de idade. Brasil, 2001 
8 Taxa salarial em reais por hora e participação da renda da criança na renda familiar, das crianças de 6 a 15 anos, segundo grupos de idade e engajamento escolar. Brasil, 2001.

9 Jornada semanal média de crianças de 6 a 15 anos que estudam e que não

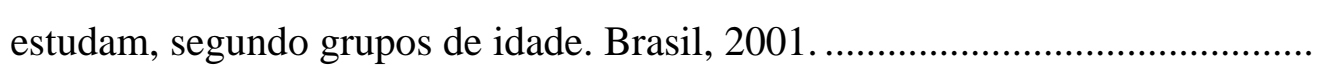

10 Remuneração média mensal do trabalho principal das crianças de 6 a 15 anos que estudam e que não estudam, segundo grupos de idade. Brasil, 2001. . 


\section{LISTA DE SIGLAS}

ECA - Estatuto da Criança e do Adolescente

FFE - Food-for-Education

IBGE - Instituto Brasileiro de Geografia e Estatística

MAPS - Ministério da Assistência e Promoção Social

MISA - Minimun Income for School Attendance

OIT - Organização Internacional do Trabalho

PETI - Programa de Erradicação do Trabalho Infantil

PNAD - Pesquisa Nacional por Amostra de Domicílio

Progresa - Programa Nacional de Educación, Salud y Alimentación 


\section{LISTA DE TABELAS}

Página

1 Estimativa do percentual de crianças de 5-14 anos economicamente ativas, 2000 .

2 Número e percentual de crianças economicamente ativas, trabalho infantil e piores formas de trabalho infantil em 2000 (por idade).

3 Percentual de crianças de 6 a 15 anos que só estudam, só trabalham, estudam e trabalham ou não estudam nem trabalham, segundo grupos de idade e situação de domicílio; Brasil, 2001.

4 Média da renda per capita familiar mensal, em reais, descontada a renda da criança, de crianças de famílias pobres entre 6 e 15 anos que só estudam, só trabalham, estudam e trabalham ou não estudam nem trabalham, segundo grupos de idade e situação de domicílio; Brasil, 2001.

5 Taxa salarial em reais por hora e participação da renda da criança na renda familiar, das crianças de 6 a 15 anos, segundo grupos de idade, engajamento escolar e situação de domicílio; Brasil, 2001.

6 Jornada de trabalho semanal média de crianças de 6 a 15 anos que estudam e que não estudam, segundo grupos de idade e situação de domicílio; Brasil, 2001.

7 Remuneração média mensal do trabalho principal, em reais, das crianças de 6 a 15 anos que estudam e que não estudam, segundo grupos de idade e situação de domicílio; Brasil, 2001. 
8 Média ponderada das variáveis utilizadas.................................................... 73

9 Equações de trabalho de crianças de 6 a 15 anos de famílias com renda per capita mensal igual ou inferior a meio salário mínimo.............................

10 Equações de salários estimadas para pais e mães, utilizando o

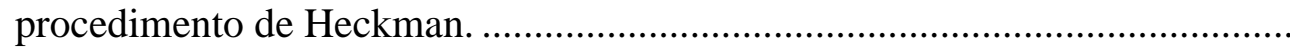




\title{
AVALIAÇÃO DO IMPACTO DOS PROGRAMAS DE BOLSA ESCOLA NO TRABALHO INFANTIL NO BRASIL
}

\author{
Autora: ANDREA RODRIGUES FERRO \\ Orientador: Profa. Dra. ANA LÚCIA KASSOUF
}

\section{RESUMO}

Há um consenso na literatura de que a criança que trabalha tem um rendimento escolar menor, e atingirá um nível de escolaridade final mais baixo do que o alcançado por aquelas que não trabalham. Conseqüentemente, quando adultos, terão salários menores do que os indivíduos que começaram a trabalhar mais tarde, e esse mecanismo é o que também se conhece como ciclo de perpetuação da pobreza. Partindo da hipótese de que as crianças trabalham para complementar a renda da família - ou seja, trabalham porque são pobres - as iniciativas que visam o combate ao trabalho infantil ajudam a diminuir as diferenças entre pobres e não-pobres, uma vez que atua numa de suas causas. Enfim, são ações capazes de quebrar o ciclo que mantém pobres várias gerações de uma mesma família. Os programas Bolsa Escola em geral não exigem formalmente que a criança seja afastada de atividades laborais para que o benefício the seja concedido. Porém, como existe a obrigatoriedade da frequiência escolar, que reduz o tempo disponível para outras atividades, e é realizada transferência em dinheiro que substituiria a renda do trabalho da criança, entende-se que a saída do mercado de trabalho é um efeito colateral ou transbordamento (spillover) de um programa cujo objetivo explícito é incentivar a demanda por educação formal e aliviar a pobreza corrente. Avaliou-se o impacto dos programas de bolsa escola sobre o trabalho infantil no Brasil, utilizando os microdados da PNAD 2001, por meio de duas estratégias complementares: i) modelo próbite em que a variável dependente é um se a criança 
trabalha e zero se não trabalha; e ii) regressão por mínimos quadrados ponderados, para as crianças que trabalham, em que a variável dependente é o número de horas semanais trabalhadas por mês. É possível concluir que o programa é eficiente na redução do número de horas mensais de trabalho das crianças, e que uma bolsa adicional diminui jornada das crianças que trabalham em duas horas na área urbana e três horas na área rural. No entanto, os testes realizados não foram conclusivos em relação à decisão da família de inserir suas crianças no mercado de trabalho. 


\title{
IMPACT EVALUATION OF BOLSA ESCOLA PROGRAMS ON CHILD LABOR IN BRAZIL
}

\author{
Author: ANDREA RODRIGUES FERRO \\ Advisor: Profa. Dra. ANA LÚCIA KASSOUF
}

SUMMARY

There is a consensus in the literature that if a child works his/her level of schooling will decrease and consequently he/she will receive lower wages in adult life, forcing their children to work to guarantee family subsistence. Based on the hypothesis that children work to complement family income, the initiatives to eradicate child labor helps to diminish the differences between the poor and non-poor. The minimum income for school attendance programs - like bolsa escola in Brazil - in general do not request formally that the child quits his/her job to receive the benefit. However, since school attendance is mandatory, which reduces the available time for other activities, and there is a cash transfer that substitutes the child's income from work, the decrease in the labor market participation is a spillover effect of the program, whose objectives are to stimulate the demand for formal education and to alleviate current poverty. As a way to evaluate the impact of the bolsa escola programs on the child labour in Brazil, based on microdata from PNAD 2001, a regression model was estimated by weighted least squares for the weekly hours worked by children and a probit model for the family's decision of children's participation in the labor force. It is possible to conclude that the program is really efficient to decrease children's weekly hours of work, but the test for participation in the labor force was inconclusive. An additional bolsa has diminished in two hours the weekly hours worked by children in rural areas and in three hours in urban areas. 


\section{INTRODUÇÃO}

"O começo é mais do que a metade do todo. Porque começar é o mais difícil”.

Horácio

\subsection{Justificativa}

Há um consenso na literatura de que a criança que trabalha tem um rendimento escolar menor, e atingirá um nível de escolaridade final mais baixo do que o alcançado por aquelas que não trabalham. Conseqüentemente, quando adultos, terão salários menores do que os indivíduos que começaram a trabalhar mais tarde. Esse mecanismo é um dos componentes do que também é conhecido como ciclo de perpetuação da pobreza.

Partindo da hipótese de que as crianças trabalham para complementar a renda da família - ou seja, trabalham porque são pobres - as iniciativas que visam o combate ao trabalho infantil ajudam a diminuir as diferenças entre pobres e não-pobres, uma vez que atua numa de suas causas. Enfim, são ações capazes de quebrar o ciclo que mantém pobres várias gerações de uma mesma família.

Como será visto no desenvolvimento da pesquisa, os programas de transferência de renda condicionada à educação em andamento no Brasil, conhecidos como Bolsa Escola, em geral não exigem que a criança seja afastada de atividades laborais para que o benefício lhe seja concedido. Porém, como existe a obrigatoriedade da freqüência escolar, que reduz o tempo disponível para outras atividades, e é realizada transferência em dinheiro que substituiria a renda do trabalho da criança, entende-se que a saída do mercado de trabalho é um efeito colateral ou transbordamento (spillover) de programas cujo objetivo explícito é incentivar a demanda por educação formal. 
Entretanto, é observado que $13 \%$ das crianças beneficiadas pelos programas Bolsa Escola no Brasil continua trabalhando, o que indica a necessidade de avaliar esse tipo de política social. Outro aspecto que reforça a importância de avaliações de programas de renda mínima vinculada à educação é que os próprios governos colocam na sua pauta a eficiência dessas ações, questionando se esta é realmente a melhor forma de combater a pobreza e erradicar o trabalho infantil, tanto no curto quanto no longo prazo.

No Brasil há estudos avaliando o impacto dos programas Bolsa Escola do Distrito Federal e Renda Mínima em Campinas, de outras experiências municipais e do Programa de Erradicação do Trabalho Infantil, além de simulações dos resultados da implantação do Bolsa Escola em escala federal. No entanto, avaliações ex-post do impacto dos programas de Bolsa Escola sobre a alocação do tempo das crianças ainda estão sendo feitas, e apenas um trabalho científico com as características desta dissertação foi encontrado no decorrer da pesquisa, reforçando a importância, a necessidade e a atualidade deste estudo.

\subsection{Objetivos}

\subsubsection{Objetivo geral}

O objetivo geral desta pesquisa é verificar o impacto dos programas de renda mínima vinculados à educação - Bolsa Escola - sobre o trabalho infantil no Brasil.

\subsubsection{Objetivos específicos}

São objetivos específicos do trabalho:

i. identificar um método adequado para a avaliação ex-post do impacto dos programas Bolsa Escola sobre o trabalho infantil no Brasil;

ii. preparar a base de dados compatível com o método proposto, utilizando 
os microdados da Pesquisa Nacional por Amostra de Domicílios (PNAD) 2001;

iii. aplicar o método escolhido à base de dados para avaliar o impacto dos programas Bolsa Escola sobre o trabalho infantil no Brasil.

\subsection{Estrutura do Trabalho}

Este trabalho é dividido em quatro partes, além desta introdução. O capítulo 2 consiste de uma revisão bibliográfica em que se discute o que é o trabalho infantil, quais suas causas e conseqüências, destacando brevemente as principais contribuições científicas sobre o tema. Em seguida as principais políticas sociais propostas para a eliminação do trabalho infantil são apresentadas, e os programas de transferência de renda vinculada à educação - Bolsa Escola - são descritos. Nesta parte também são discutidos os métodos de avaliação de políticas públicas, principalmente de transferência de renda condicionada, como é o caso do Bolsa Escola e Renda Mínima brasileiros ou do Programa Nacional de Educação, Saúde e Alimentação (Progresa) mexicano, agrupados na Organização Internacional do Trabalho (OIT) sob a denominação Minimum Income for School Attendance (MISA).

Na terceira parte o modelo de determinação de trabalho infantil considerado mais apropriado para os objetivos desta pesquisa é detalhado, e o método para avaliação ex-post de programas Bolsa Escola como instrumento de combate ao trabalho infantil no Brasil é escolhido. Ainda neste capítulo a base de dados e as variáveis utilizadas no modelo são apresentadas.

No capítulo 4 são apresentadas as estatísticas descritivas da amostra utilizada, bem como os principais resultados econométricos, que são discutidos detalhadamente. No quinto capítulo estão as conclusões, que encerram esta pesquisa. 


\section{REVISÃO BIBLIOGRÁFICA}

"O trabalho espanta três males: o vício, a pobreza e o tédio".

Voltaire

"Época triste é a nossa em que é mais difícil quebrar um preconceito do que um átomo".

Einstein

Neste capítulo será apresentada uma revisão da literatura nacional e internacional abordando o trabalho infantil e as medidas comumente adotadas para combatê-lo, bem como a avaliação de tais medidas.

O primeiro tópico traz uma visão geral do trabalho infantil no mundo e no Brasil, quantificando e explicitando pontos importantes que serão tratados no decorrer desta pesquisa. Os números mostrados dão uma idéia da dimensão do problema e da importância de pesquisas na área.

Em seguida, os principais estudos científicos sobre as causas e as conseqüências do trabalho precoce são apresentados, de forma que a racionalidade de programas sociais voltados à erradicação do trabalho infantil e ao combate à pobreza seja esclarecida.

Esse arcabouço teórico permite entender os pontos-chave geralmente abordados em avaliações de políticas sociais e a opção por determinadas técnicas de avaliação encontradas na literatura recente, cuja revisão bibliográfica finaliza este capítulo.

\subsection{Contextualização: o trabalho de crianças e adolescentes}

Vários esforços são feitos para redução e eliminação do trabalho infantil, que vão desde estudos no campo da sociologia, economia e direito, até a implementação de 
leis nacionais e tratados internacionais. Entretanto, o conceito de trabalho infantil pode não ser tão simples quanto parece, pois a própria definição de infância difere de um país ${ }^{1}$ para outro, assim como a idéia relacionada ao trabalho da criança.

É importante fazer a distinção entre trabalho infantil e exploração de mão-deobra infantil ${ }^{2}$. Segundo Peres et.al. (2003) a própria Organização Internacional do Trabalho (OIT) afirma que

“as crianças ajudam desde cedo suas famílias nos afazeres do lar, no campo, em lojas etc. Essas atividades, porém, não são as que chamamos de trabalho infantil. $\mathrm{O}$ conceito aplica-se melhor àquelas desempenhadas por menores, em condições mais ou menos regulares, para ganhar o sustento para si e suas famílias"

Além disso, o trabalho pode exercer uma função educativa, e o fato de alguns pais delegarem aos filhos a tarefa de arrumar a própria cama, lavar um copo após utilizálo, ou até mesmo a responsabilidade por algumas tarefas simples no campo, tais como recolher ovos ou alimentar galinhas, não poderia ser considerada exploração de mão-deobra infantil, mas sim um processo de aprendizado.

A questão é então o que separa o trabalho da exploração de mão-de-obra infantil. Além das diferenças entre países e culturas, épocas distintas num mesmo país também são importantes para definir se o trabalho de crianças é ou não socialmente aceito. Durante o feudalismo, por exemplo, era importante começar a trabalhar o quanto antes para aprender um ofício, pois os artesãos eram pessoas importantes nas comunidades. Por muito tempo a infância não foi considerada um período especial na vida do indivíduo, mas sim uma preparação para a vida adulta.

No Brasil, é possível perceber a diferença cultural que separa épocas distintas a

\footnotetext{
${ }^{1}$ Segundo Kassouf (2002), em algumas regiões a infância refere-se à idade cronológica, enquanto em outras se leva em consideração fatores sócio-culturais, e, portanto a legislação que trata do trabalho infantil também varia de um país para outro.

${ }^{2}$ Apesar de existir uma distinção entre os conceitos de trabalho e exploração de mão-de-obra, ainda é uma questão polêmica entre cientistas e sociedade civil organizada se algum tipo de trabalho durante a infância pode ser considerada educativa.
} 
partir dos dados da Pesquisa Nacional por Amostra de Domicílios (PNAD) de 2001, observando a idade média em que se começou a trabalhar segundo grupos de idade atual.

É interessante observar que quanto mais velhos os adultos da amostra, mais cedo começaram a trabalhar. A Figura 1 mostra que $43 \%$ da população adulta começou a trabalhar quando tinha entre dez e catorze anos, e que apenas $18 \%$ entrou no mercado de trabalho após os dezoito anos. Ou seja, há cerca de quarenta anos era muito comum começar a trabalhar cedo, e a proporção de pessoas que entraram no mercado de trabalho antes dos nove anos é muito maior entre os que hoje têm mais de 45 anos do que entre os que têm menos de 25. Da mesma forma, entre os que têm entre dezoito e 25 anos a proporção dos que entraram no mercado quando tinham entre quinze e dezessete anos é bem maior do que entre os que têm mais de 45 anos.

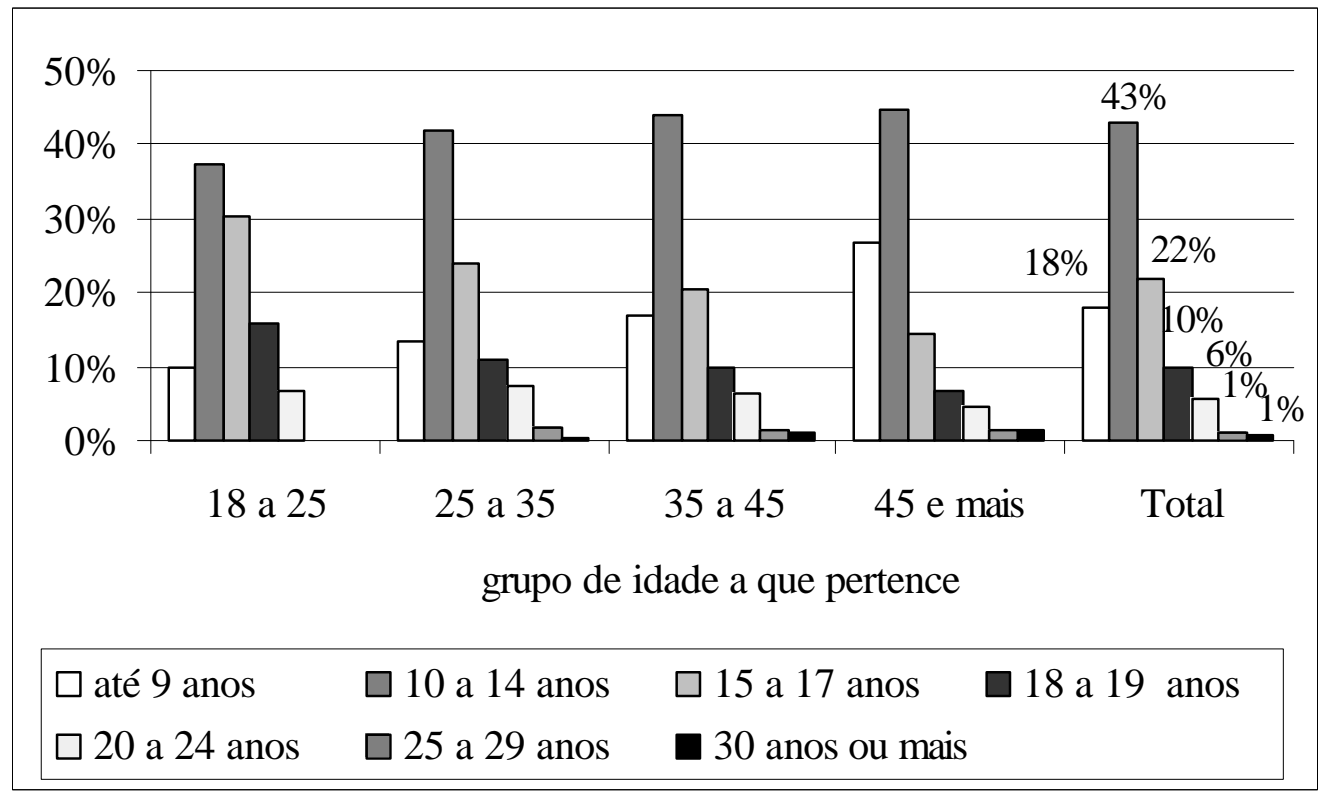

Figura 1 - Participação dos grupos de idade em que começou a trabalhar segundo grupos de idade da população adulta; Brasil, 2001.

Outro ponto interessante no que diz respeito à definição e distinção entre trabalho e exploração de mão-de-obra infantil é o caso de atores e modelos mirins, em 
que os próprios pais incentivam e levam seus filhos para longas sessões de fotos e gravações. Existem várias discussões a respeito deste tipo de trabalho e suas conseqüências para o desenvolvimento da criança, que estão fora do escopo desta pesquisa, mas que representam o trabalho infantil que contribui para o sustento ou aumento da riqueza da família, e que nos dias atuais é socialmente aceito na maior parte dos países.

Para os objetivos aqui propostos, quando o termo "trabalho infantil" é utilizado, refere-se ao conceito de exploração de mão-de-obra, que traz consequiências negativas para as crianças.

A definição de trabalho infantil também pode ser feita em termos de legislações ou normas nacionais e internacionais. A OIT considera criança o indivíduo com 15 anos ou menos, e a criança é considerada trabalhadora se faz parte da população economicamente ativa, independentemente de estar ou não trabalhando (Jafarey \& Lahiri, 2001). Entretanto, muitos países ainda não ratificaram a Convenção $n^{\circ} 138$ e a Recomendação $\mathrm{n}^{\circ}$ 146, que tratam dos direitos das crianças, principalmente daquelas que exercem algum tipo de atividade laboral, no intuito de erradicar o trabalho infantil como definido pelo órgão internacional.

A Convenção n. 138 da OIT, aprovada em Genebra em 1973, estabelece a idade mínima para ingresso no mercado de trabalho em 16 anos, e até esta idade o engajamento escolar compulsório, além de tratar, juntamente com a Recomendação 146, de políticas nacionais para erradicação do trabalho infantil, das condições de emprego e das definições de trabalho perigoso, só permitido a partir dos 18 anos.

No Brasil, o Estatuto da Criança e do Adolescente (ECA) define a criança em termos de idade (Brasil, 1990):

Capítulo I, Artigo 2: "Para finalidade dessa lei, a criança é definida como uma pessoa que ainda não completou 12 anos de idade, enquanto que o adolescente tem entre 12 e 18 anos de idade".

E o mesmo estatuto ainda afirma que: 
Capítulo V, Artigo 60: "É proibido qualquer trabalho a crianças menores de 14 (quatorze) anos, salvo na condição de aprendiz."

Em 1998, foi aprovada no Congresso Nacional uma emenda constitucional que altera o artigo $7^{\circ}$, inciso XXXIII, cujo texto afirma que

“Trabalho noturno e perigoso é proibido para crianças menores de 18 anos de idade, enquanto qualquer forma de trabalho é proibido a menores de 16 anos, salvo na condição de aprendiz, a partir de 14 anos".

A legislação brasileira sobre os direitos das crianças, cujo marco regulatório é a aprovação do ECA, é uma das mais rígidas em relação à idade mínima de ingresso no mercado de trabalho, equiparando-se aos Estados Unidos e à França. Na Inglaterra, por exemplo, a idade mínima é de 13 anos; Na Bélgica e na maioria dos países da América Latina é de 14; e em países como Suíça, Alemanha, Itália e Chile a idade mínima é 15 anos (International Labour Organization - ILO, 1998).

O Departamento de Estatística da Organização Internacional do Trabalho estima em 120 milhões o número de crianças entre cinco e catorze anos trabalhando em tempo integral apenas nos países menos desenvolvidos. Se forem considerados os que trabalham em tempo parcial este número chega a 250 milhões (61\% na Ásia, 32\% na África e o restante na América Latina). Em 1995, a estimativa era de 73 milhões de crianças trabalhando nos três continentes. A Tabela 1 mostra as estimativas da OIT para 2000, considerando as crianças de cinco a catorze anos segundo as regiões do mundo em que vivem (ILO, 1998; ILO, 2002). 
Tabela 1. Estimativa do percentual de crianças de 5-14 anos economicamente ativas no mundo, 2000.

\begin{tabular}{lccc}
\hline \multicolumn{1}{c}{ Região } & $\begin{array}{c}\text { Número de crianças } \\
\text { economicamente } \\
\text { ativas (milhões) }\end{array}$ & $\begin{array}{c}\text { \% do total global } \\
\text { por grupo }\end{array}$ & $\begin{array}{c}\text { \% de crianças } \\
\text { economicamente } \\
\text { ativas no total da } \\
\text { população infantil }\end{array}$ \\
\hline Economias desenvolvidas (industrializa & 2.5 & 1 & 2 \\
Economias em transição & 2.4 & 1 & 4 \\
Ásia e Pacífico & 127.3 & 60 & 19 \\
América Latina e Caribe & 17.4 & 8 & 16 \\
África Sub-Saariana & 48 & 23 & 29 \\
Oriente Médio e África do Norte & 13.4 & 6 & 15 \\
Total & 211 & - & 16 \\
\hline
\end{tabular}

Fonte: ILO (2002, p.19)

${ }^{1}$ Erros de arredondamento fazem com que o percentual total não seja igual a 100.

Nota: O número de crianças entre 5-14 anos no mundo em 2000 era aproximadamente 1.200 milhões, das quais $28 \%$ estavam na região Ásia - Pacício e 7,4\% na África Sub-Saariana.

Os números apresentados podem estar subestimados, uma vez que nem todos os países têm pesquisas populacionais que envolvam o trabalho infantil, e na maioria das vezes este tópico só é pesquisado para crianças acima de 10 anos de idade. Em outros casos as crianças trabalham no próprio domicílio, sendo responsáveis pelo cuidado de irmãos mais novos ou tarefas domésticas, enquanto os pais saem para trabalhar, e a família não declara por não considerar que a criança esteja trabalhando, o que também contribui para a subestimação dos dados (ILO, 1998; ILO, 2002).

O trabalho infantil não está restrito apenas aos países e regiões menos desenvolvidos, mas também é possível observar crianças trabalhando no chamado primeiro mundo. Todavia, este trabalho não é considerado como necessidade de sobrevivência, e sim desejo de consumo pessoal, e às vezes interpretado como não prejudicial aos estudos por ser de tempo parcial. Segundo Kassouf (2002), esta é uma afirmativa polêmica, com a qual muitos autores não concordam. 
Vilela (1998) destaca que o trabalho infantil ocorre entre famílias vulneráveis, mais sujeitas a choques conjunturais e idiossincráticos, pois os gastos com necessidades mínimas de sobrevivência ocupam toda sua renda, e algumas destas famílias se vêem obrigadas a inserir suas crianças no mercado de trabalho e "até mesmo a 'venda' de crianças, jogando-as no regime de escravidão”. A autora ressalta ainda que cada país tem uma realidade diferente, e conseqüentemente suas políticas para solucionar o problema devem ser adequadas e não apenas copiadas.

Além de o trabalho infantil ser prejudicial porque limita o tempo disponível para outras atividades, esses indivíduos sofrem com o trabalho perigoso, como o corte de cana e sisal na agricultura, alto-fornos em olarias e cerâmicas no ramo industrial, por exemplo, e também com o trabalho forçado ou escravo, a exploração e abuso sexual e o tráfico de crianças.

A Tabela 2 mostra as estimativas da OIT sobre o trabalho infantil perigoso no mundo em 2000. São 351 milhões de crianças entre cinco e dezessete anos economicamente ativas, das quais cerca de $60 \%$ com menos de quinze anos. Dos 245 milhões de trabalhadores desta idade, $73 \%$ estão empregados nas piores formas de trabalho infantil: 170 milhões exercem trabalho perigoso e 8 milhões de crianças são empregadas nas formas inquestionavelmente perversas, como são conhecidos: o trabalho escravo ou forçado, a utilização de crianças em conflito armado, prostituição, pornografia e tráfico de drogas, além do tráfico de crianças e órgãos. 
Tabela 2. Número e percentual de crianças economicamente ativas, trabalho infantil e piores formas de trabalho infantil em 2000 (por idade).

\begin{tabular}{|c|c|c|c|c|c|c|}
\hline & \multicolumn{2}{|c|}{$5-14$ anos } & \multicolumn{2}{|c|}{$15-17$ anos } & \multicolumn{2}{|c|}{ Total } \\
\hline & $\begin{array}{l}\text { Número } \\
\text { (milhões) }\end{array}$ & $\begin{array}{l}\% \text { do } \\
\text { grupo de } \\
\text { idade }\end{array}$ & $\begin{array}{l}\text { Número } \\
\text { (milhões) }\end{array}$ & $\begin{array}{c}\% \text { do } \\
\text { grupo de } \\
\text { idade }\end{array}$ & $\begin{array}{l}\text { Número } \\
\text { (milhões) }\end{array}$ & $\begin{array}{c}\% \text { do } \\
\text { grupo de } \\
\text { idade }\end{array}$ \\
\hline Crianças economicamente ativas & 210,8 & 18 & 140,9 & 42 & 351,7 & 23 \\
\hline $\begin{array}{l}\text { das quais: trabalhadores } \\
\text { infantis }\end{array}$ & 186,3 & 16 & 59,2 & 18 & 245,5 & 16 \\
\hline $\begin{array}{l}\text { dos quais: crianças nas piores } \\
\text { formas de emprego infantil }\end{array}$ & - & - & - & - & 178,9 & 11,5 \\
\hline $\begin{array}{l}\text { crianças em trabalho } \\
\text { perigoso }\end{array}$ & 111,3 & 9 & 59,2 & 18 & 170,5 & 11 \\
\hline $\begin{array}{l}\text { crianças em piores formas } \\
\text { incondicionais* }\end{array}$ & - & - & - & - & 8,4 & 0,5 \\
\hline
\end{tabular}

Fonte: ILO (2002, p.19)

" - " dados não disponíveis.

* trabalho forçado ou escravo (5,7 milhões); conflito armado ( 0,3 milhão); protituição e pornografia (1,8 milhão); outras atividas ilícitas ( 0,6 milhão); tráfico de crianças (1,2 milhão, incluídos em outras piores formas).

No Brasil, os microdados da Pesquisa Nacional por Amostra de Domicílios (PNAD) de 2001, que traz encarte especial sobre trabalho infantil, mostram que existem aproximadamente 3,5 milhões de crianças de cinco a quinze anos de idade que estão empregadas ou procurando emprego, o que representa $10 \%$ dos indivíduos nessa faixa etária $^{3}$. Ainda em relação a este grupo de crianças, $91 \%$ têm mais de dez anos de idade.

A Figura 2 mostra que a participação das crianças no mercado de trabalho está relacionada ao grupo de idade a que pertencem. Assim, enquanto no grupo que tem

\footnotetext{
${ }^{3}$ Para o caso brasileiro foi escolhido o grupo que tem de cinco a quinze anos, pois a partir dos dezesseis anos é permitido o trabalho, exceto o perigoso.
} 
menos de dez anos a taxa de participação na força de trabalho é de $2 \%$, no grupo com dez anos ou mais essa taxa sobe para $16 \%$.

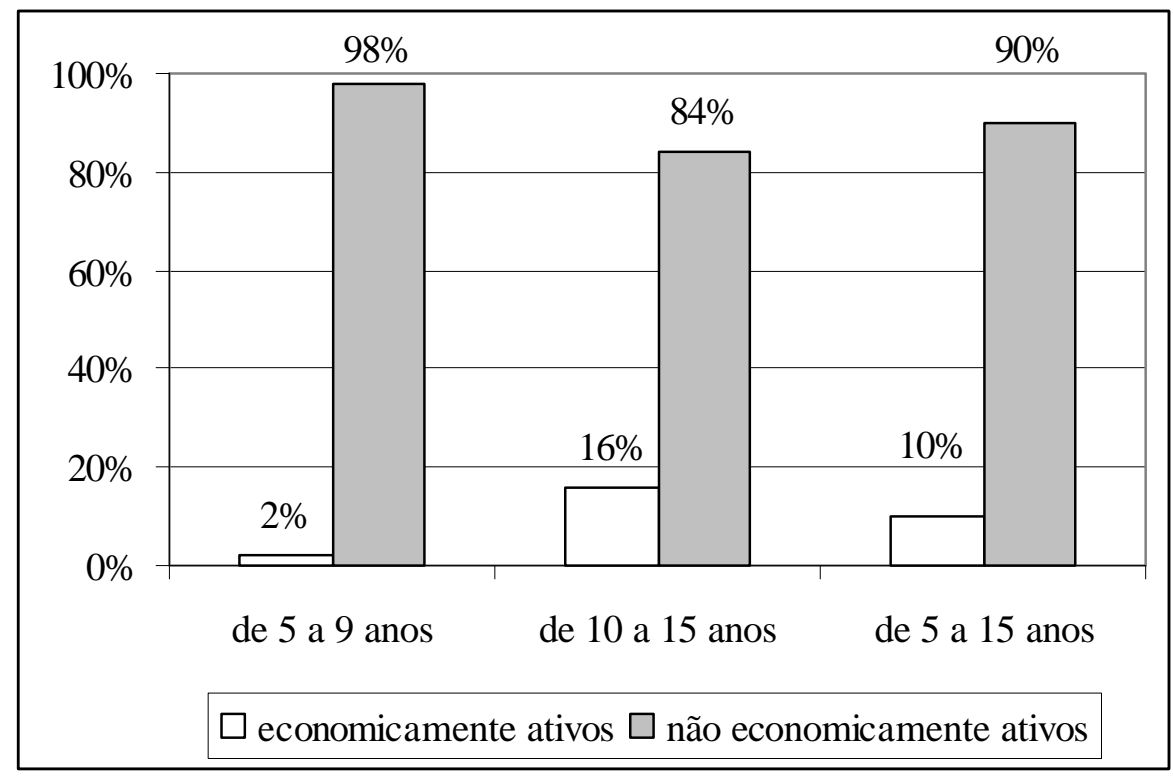

Figura 2 - Percentual de crianças de 5 a 15 anos economicamente ativos, segundo grupos de idade; Brasil, 2001.

Outra informação relevante para os objetivos deste trabalho é o percentual de crianças que recebem benefícios de programas sociais de incentivo à educação, como Bolsa Escola, Renda Mínima e Programa de Erradicação do Trabalho Infantil (PETI), mas que continuam trabalhando.

A Figura 3 mostra que $13 \%$ das crianças que recebem benefícios deste tipo continuam trabalhando. No grupo dos mais velhos esta proporção chega a $19 \%$ dos beneficiários, enquanto entre os mais novos é de 5\%. Esses resultados reforçam a necessidade de avaliações ex-post do programa, uma vez que a saída dessas crianças do mercado de trabalho é um efeito esperado, embora do tipo "transbordamento", dos programas que vinculam a transferência de renda à frequiência escolar. 


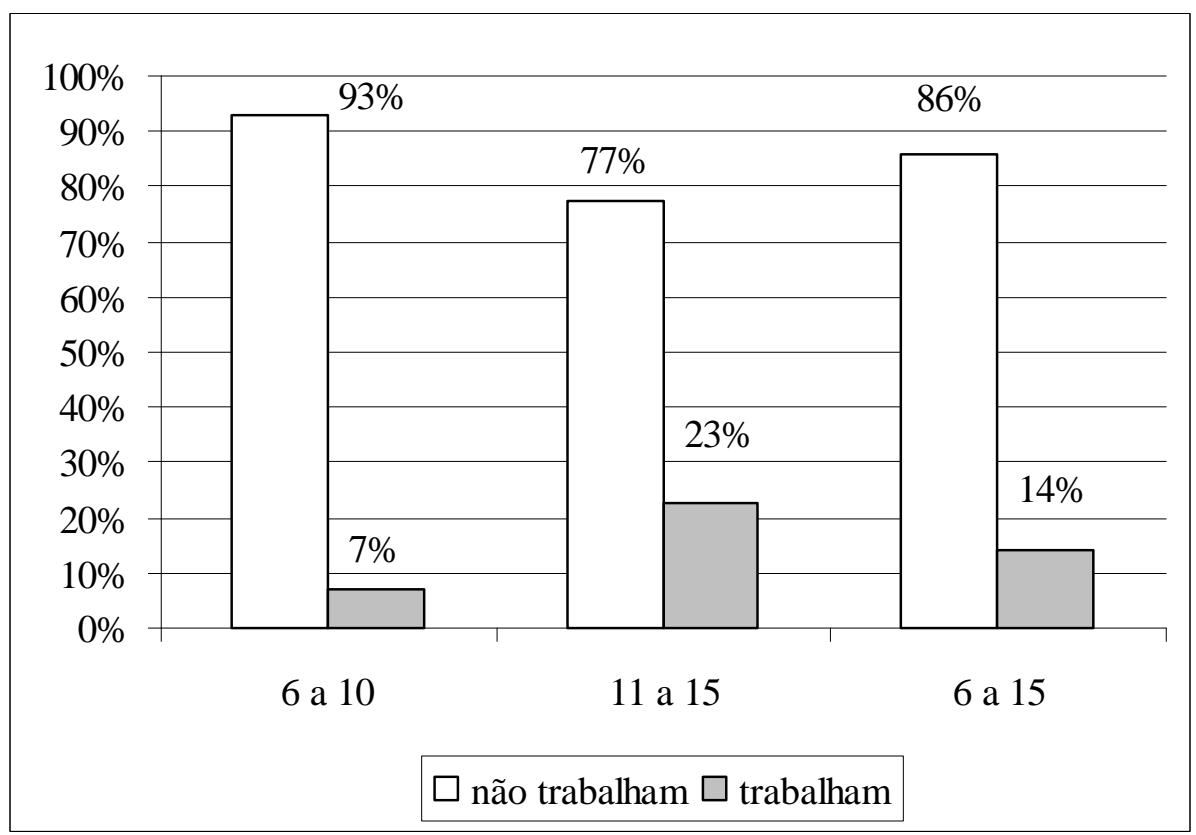

Figura 3 - Crianças inscritas em programas sociais de incentivo à educação, segundo ocupação e grupos de idade; Brasil, 2001.

Inúmeros trabalhos científicos já foram feitos para descrever e entender o que leva as famílias a inserirem suas crianças no mercado de trabalho quando estas têm ainda a opção do estudo ${ }^{4}$, bem como para discutir os principais efeitos do trabalho precoce no curto e no longo prazo, tanto para o indivíduo quanto para a sociedade.

Basu (1999) destaca que apesar de haver numerosas pesquisas sobre o trabalho infantil, a grande maioria concentra-se em análises empíricas ou econométricas e são poucas as que tratam de modelos econômicos teóricos. Alguns destes trabalhos, empíricos e teóricos, serão discutidos a seguir, com o objetivo de estabelecer um referencial teórico para a posterior análise dos programas de combate e erradicação do trabalho infantil.

Segundo a teoria neoclássica (Berndt, 1991), o salário de reserva é um importante determinante de entrada ou não no mercado de trabalho: o indivíduo

\footnotetext{
${ }^{4}$ Basu (1999) descreve as primeiras contribuições, dadas por Karl Marx, Alfred Marshall e Arthur Pigou.
} 
participará da força de trabalho quando o salário de mercado for maior que seu salário de reserva $^{5}$. Esse condicionante será válido no caso da oferta de trabalho de crianças, independentemente do processo de decisão que a unidade familiar adota para alocar o tempo de seus membros.

Geralmente, considera-se que os pais são altruístas em relação aos filhos. Portanto, a decisão dos pais de inserir as crianças no mercado de trabalho apenas se daria num contexto em que a sobrevivência da família estivesse ameaçada. Assim, principalmente a pobreza, seguida da educação dos pais, da baixa atratividade da escola, de componentes culturais e outros aspectos de background familiar aparecem na literatura como os principais determinantes do trabalho infantil, pelo lado da oferta.

Rosenzweig (1981) modela a alocação do tempo dos jovens entre tarefas domésticas e não domésticas, assumindo que a família maximiza uma função utilidade contínua, estritamente crescente, quase-côncava e diferenciável, e que a utilidade é função de bens comprados e consumidos, do tempo de lazer da mãe e do pai, do tempo de lazer da criança, e do nível de escolaridade da criança. Assume-se também que o nível de escolaridade da criança requer tempo e alguns bens específicos à educação, tais como material escolar, taxas escolares, transporte, etc. A restrição de renda total com a qual a família se defronta é dada pela renda não-salarial, e pelos salários da mãe, do pai e da criança. A partir desses pressupostos o autor analisa o efeito de uma variável exógena sobre as endógenas, fazendo a distinção entre os efeitos preço (utilidade constante) e renda.

Aplicando o modelo para a Índia rural, Rosenzweig (1981) observou que aumentos nos salários das crianças reduziam a taxa de frequiência das crianças às escolas, e o mesmo ocorria quando o salário da mãe aumentava, pois neste caso a mãe trabalha fora e a criança deixa de freqüentar a escola para cuidar da casa. Notou ainda que o tempo de trabalho das filhas diminuía significativamente mais que o dos filhos

\footnotetext{
${ }^{5}$ No entanto, o salário de reserva de um indivíduo não é diretamente observável; é possível apenas saber se ele é maior ou igual ou se é menor que o salário vigente, quando o indivíduo opta por entrar ou não no mercado de trabalho.
} 
quando ocorria um aumento no salário das mães, considerando como trabalho das crianças as atividades, remuneradas ou não, exercidas fora de seu domicílio. A partir destes resultados, ele concluiu que mães e filhas eram substitutos próximos no que se refere à alocação do tempo entre escola e atividades no domicílio.

Segundo Basu \& Van (1988), que modelam o equilíbrio no mercado de trabalho com e sem a participação de crianças, a decisão de entrar no mercado de trabalho no caso de crianças é tomada pelos pais, considerando que cada família tem uma única função de utilidade. Os autores notam que tal suposição permite o nível de abstração necessário num modelo que descreva a oferta de trabalho infantil. Em relação às críticas por haver evidências de que o padrão de consumo da família difere conforme quem toma a decisão e quem ganha o dinheiro, afirmam que o modelo proposto não nega a possibilidade de decisões distintas sobre a inserção das crianças no mercado de trabalho caso fossem tomadas por outros membros da família. Basu \& Van (1988) desenvolvem um ferramental gráfico para avaliar os efeitos de políticas intervencionistas nestes mercados sobre o bem-estar das famílias, e concluem que banir o trabalho infantil eleva os salários dos adultos, ou aumenta o nível de emprego quando os salários são rígidos, e assim as famílias decidiriam não enviar os filhos ao mercado de trabalho, tornando a proibição desnecessária. Entretanto, os resultados são condicionados ao tamanho ou ao nível de desenvolvimento da região em que se impõe a restrição.

Crianças e adolescentes apresentam características diferentes no mercado de trabalho, quer pela representatividade na força de trabalho, quer pelo tamanho da jornada ou ainda pelos motivos que os levam a ingressar precocemente em atividades laborais. Assim, pode-se inferir que a criança com menos de dez anos que exerce uma atividade perigosa na área rural do nordeste, por exemplo, tem motivos diferentes para ingressar no mercado dos de um adolescente que vive em grandes cidades no sudeste.

Segundo Saboia \& Bregman (1993),

"a observação dos dados das Pnads da década de 80 nos mostra que crianças e adolescentes têm comportamento bastante diferenciado, apresentando movimentos distintos em relação à evolução de suas 
taxas de atividade".

Assim, diante do fato de os adolescentes terem taxa de atividade maior no Sudeste que no Nordeste, os autores apresentam duas situações que podem explicar tais diferenças: primeiro, o mercado de trabalho no Sudeste é mais dinâmico, e portanto capaz de absorver um número maior de adolescentes que no Nordeste; segundo

“enquanto no Nordeste os adolescentes são levados a trabalhar por uma situação de extrema pobreza e necessidade de participar de forma mais efetiva no orçamento doméstico, no Sudeste, onde há maior oferta de bens de consumo, os adolescentes são mais pressionados a trabalhar para satisfazer suas próprias necessidades".

Estudo analisando dados brasileiros de 1960 a 1980 (Barros, Mendonça \& Velazco, 1994), conclui que a pobreza não é o componente principal da incidência do trabalho infantil, e que características culturais e familiares deveriam ser mais enfatizadas nos estudos sobre o tema, principalmente quando se pensa em políticas públicas para redução do trabalho infantil, pois considera a força da associação pobreza - trabalho infantil questionável, inclusive levando a uma conclusão simplista em termos de política social, ou seja, de que seria suficiente acabar com a pobreza para erradicar o trabalho infantil.

Nielsen \& Dubey (2001), com base na literatura recente, formulam quatro hipóteses acerca da existência do trabalho infantil: substituição, subsistência, mercado de capitais e educação dos pais. Testando estas hipóteses com dados da Índia para os anos de 1987/88 e 1993/94, concluíram que subsistência e escolaridade dos pais são os principais determinantes do trabalho infantil e da conseqüente "não-escolaridade" da criança. Por outro lado, a redução do trabalho infantil observada nos dados foi explicada principalmente por um aumento da renda das famílias, propiciada por uma diminuição nas restrições de crédito, além da influência da educação dos pais. Para a hipótese de substituição do trabalho do adulto pelo infantil na família, entretanto, obtiveram resultado ambíguo. 
O modelo de determinação do trabalho infantil elaborado por Rosenzweig (1981) foi descrito por Kassouf (2002), considerando que a família é composta de mãe, pai e somente uma criança. A partir do pressuposto de que a oferta de trabalho infantil é afetada basicamente pelo tamanho da família, renda e escolaridade dos pais, e utilizando os dados brasileiros da PNAD de 1995, a autora estimou modelos próbite admitindo que os pais (ou a família) alocam o tempo da criança em estudos, atividades domésticas e trabalho, levando em conta o tamanho e a estrutura da família, a produtividade dos pais e da criança e o grau de substituição entre eles.

Kassouf (2002) observou que os salários das mães e dos pais têm impacto maior entre meninos que entre as meninas, e assim "pais e mães seriam substitutos próximos dos meninos mais do que das meninas com relação ao tempo gasto com atividades sem rendimentos". Este resultado difere do obtido por Rosenzweig (1981), em que mães e meninas são consideradas substitutas próximas em relação a estas atividades, mais do que pais e meninas.

Os resultados obtidos indicam que: i) a escolaridade dos pais deve reduzir a probabilidade de as crianças trabalharem e aumentar a probabilidade de sua frequiência à escola; ii) o tamanho do domicílio influencia a probabilidade de trabalho, mas a presença do irmão mais velho não deixa clara a substituição de mão-de-obra entre eles, como em outros países; iii) o salário do pai exerce maior efeito sobre a probabilidade de a criança trabalhar, e o da mãe sobre a probabilidade de a criança estudar. Da mesma forma a escolaridade do pai está mais ligada ao trabalho e a da mãe à educação das crianças, principalmente das meninas. Este último resultado pode significar que mães valorizam mais o capital humano de seus filhos.

Kassouf (2002) nota ainda que “enquanto as atividades domiciliares realizadas pelas crianças podem permitir que mães ou irmãos mais velhos entrem no mercado de trabalho, as atividades de mercado realizadas pelas crianças permitem a elas contribuírem para o aumento da renda familiar". 
Do lado da demanda, estão a estrutura do mercado e a tecnologia como principais determinantes de trabalho infantil. De acordo com Kassouf (2001), as crianças representam baixo custo para o empregador, pois não são membros de sindicatos nem possuem direitos trabalhistas. Razões não-econômicas também podem ser apontadas: crianças são mais crédulas, obedientes e dispostas a realizar trabalhos considerados monótonos pelos adultos (ILO, 1998).

Além disso, o mercado de trabalho dos adultos afeta o das crianças uma vez que os empregadores poderiam preferir contratar os adultos a um dado salário, caso estes fossem mais produtivos que as crianças e recebessem apenas o salário mínimo fixado em lei. Quanto à tecnologia, a adoção de novas técnicas, a mecanização agrícola e a própria revolução industrial são exemplos de como o avanço tecnológico diminui a demanda por trabalho infantil.

Entre as principais consequiências da entrada precoce no mercado de trabalho estão o nível educacional menor e a renda mais baixa no futuro, quando comparados a obtidos por indivíduos que começaram a trabalhar mais tarde. Em outras palavras, ao tentar garantir o sustento e a sobrevivência da família no presente, inserindo crianças no mercado de trabalho, desenvolve-se um mecanismo de perpetuação da pobreza e de baixo nível educacional.

Galli (2001) identifica ainda seis maneiras através das quais o trabalho infantil tem impactos negativos no crescimento de longo prazo: "menor acúmulo de capital humano, maiores taxas de fertilidade, piores condições de saúde, menores níveis de investimento e avanço tecnológico, e maior desigualdade entre gêneros e salários”.

Em relação aos três primeiros itens (capital humano, fertilidade e saúde), a autora destaca que seus impactos são bem conhecidos nas teorias de crescimento econômico. A presença (ou abundância) de trabalho barato e não qualificado também impede que sejam feitos investimentos em capital fixo e melhoramentos de processos, impedindo o avanço tecnológico.

Os efeitos sobre o crescimento econômico provocados pelas desigualdades 
podem ser ambíguos, pois dependem das magnitudes das variáveis relacionadas, mas a maior parte dos estudos citados por Galli (2001) demonstram que são indesejáveis.

Outra conseqüência importante do trabalho precoce é que se a mão-de-obra adulta e infantil são consideradas substitutas, sua existência provoca o desemprego adulto. Uma vez que o trabalho realizado por crianças poderia ser feito por adultos, mas aquelas recebem salários muito menores, as firmas prefeririam contratá-las em detrimento da mão-de-obra adulta. Assim, o trabalho infantil aumenta a incidência de desemprego entre os adultos, que consequientemente se vêem obrigados a inserir seus filhos no mercado de trabalho, e dessa forma completar um ciclo que dá continuidade à incidência de crianças economicamente ativas. Novamente, esta análise deve ser vista com cuidado, pois se crianças e adultos não são considerados substitutos, ou se seus salários são semelhantes ou ainda se crianças são contratadas por motivos diversos ao custo da mão-de-obra, os resultados obtidos podem ser diferentes ${ }^{6}$.

Em relação ao Brasil, as conseqüências do trabalho infantil sobre a escolaridade final obtida e sobre os rendimentos dos indivíduos na vida adulta podem ser observados por meio dos dados da PNAD, conforme ilustra a Figura 4. Os adultos que começaram a trabalhar entre 25 e 29 anos de idade são os que têm, em média, os maiores salários e a segunda maior escolaridade em número de anos de estudo. Em contrapartida, os que entram no mercado de trabalho antes dos nove anos são os que têm menores salários e mais baixa escolaridade.

É possível observar também que, conforme o ingresso no mercado de trabalho é adiado, a situação do indivíduo na vida adulta melhora tanto em relação à renda quanto à educação. No entanto, quem começa a trabalhar entre os 10 e 14 anos e após os 30 apresentam renda e escolaridade médias semelhantes e próximas às médias da população adulta, que é de cerca de 6,5 anos de estudo de $\mathrm{R} \$ 334,00$ mensais.

\footnotetext{
${ }^{6}$ Pode ocorrer também que ter crianças trabalhando cause um problema moral ao empresário, que desta forma evitará o uso deste tipo de mão-de-obra, independente da relação de custos com o trabalho adulto.
} 


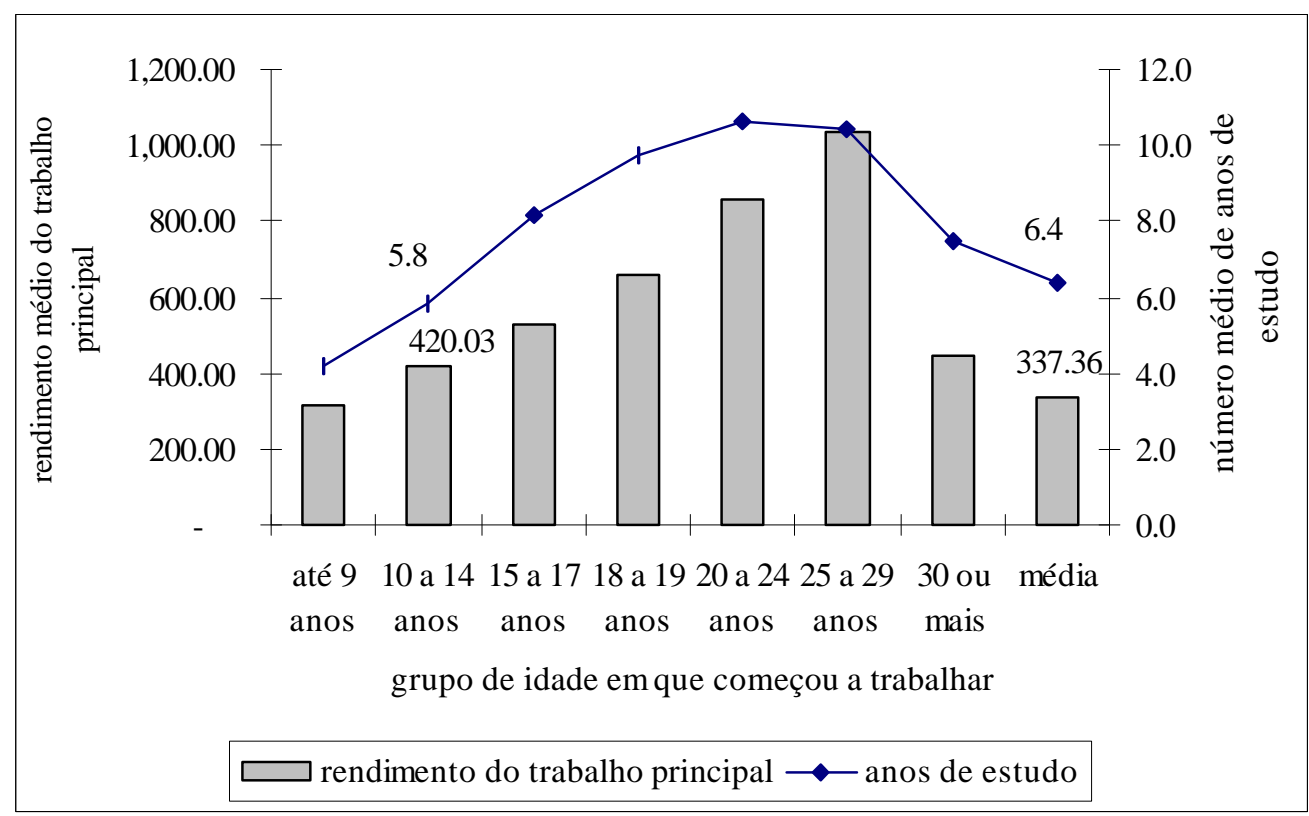

Figura 4 - Rendimento médio do trabalho principal e número médio de anos de estudo da população adulta segundo o grupo de idade em que começou a trabalhar; Brasil, 2001.

Assim, o trabalho infantil é predominantemente apontado como fruto e causa da pobreza, e a conclusão de que deve ser prontamente combatido, em todas as suas formas, parece inevitável. Entretanto, em alguns estudos podem ser encontradas justificativas para algumas formas do trabalho de crianças e adolescentes - os chamados trabalhos leves.

Considera-se, por exemplo, que educação e trabalho nem sempre são bens substitutos, uma vez que, dada a restrição de crédito com que se defrontam os indivíduos - principalmente os mais pobres - trabalhar hoje pode financiar os estudos no futuro, e esses bens poderiam ser considerados complementares.

Galli (2001) observa que trabalho infantil e escolaridade não são necessariamente mutuamente exclusivos, e que em países em desenvolvimento muitas crianças estudam e trabalham. Entretanto, nota também que o trabalho em tempo parcial pode ser prejudicial ao acúmulo de capital humano uma vez que compete com atividades 
que desenvolvem o indivíduo intelectualmente como o tempo de estudo em casa.

Mesmo a OIT, que prega a eliminação do trabalho infantil no mundo, apresenta dados em que algumas formas de trabalho são consideradas toleráveis. O relatório tem enfoque nas piores formas, e é considerado tolerável o trabalho leve realizado em tempo parcial, mas não há detalhamento de tais ocupações. Estima-se que 25 milhões de crianças entre cinco e catorze anos e 82 milhões entre quinze e dezessete anos estão engajadas em trabalhos aceitáveis (ILO, 2000).

Pode-se argumentar também que se uma criança trabalha em tempo parcial num ambiente saudável e seus estudos não são prejudicados, o trabalho seria considerado construtivo, principalmente nos casos em que a família ou o domicílio não é bem estruturado $^{7}$. A este respeito, Anker (2000) afirma que há um consenso de que algumas formas de trabalho são boas para a formação da criança, pois podem ensinar disciplina, responsabilidade e autoconfiança. Entretanto, deve-se lembrar que a existência de qualquer tipo de trabalho infantil que seja considerado educativo é ainda uma questão polêmica, e que esta pesquisa refere-se ao combate da exploração da mão-de-obra infantil como definido no início desta seção.

\subsection{As políticas de combate e erradicação do trabalho infanto-juvenil}

As políticas de erradicação do trabalho de crianças e adolescentes foram evoluindo conforme os estudos sobre o tema, e vão desde a proibição legal até programas que combinam transferência de renda e incentivo à demanda por educação (que são os chamados programas Bolsa Escola).

No estudo realizado por Kassouf (2002), por exemplo, é observado que se os adultos tiverem incentivo para entrar no mercado de trabalho, tais como melhores salários e criação de novos empregos, o trabalho infantil seria reduzido e o engajamento

\footnotetext{
${ }^{7}$ Casos em que a criança convive com pais alcoólatras, violência doméstica, ou em que o ambiente externo é ruim, facilitando, por exemplo, a criminalidade, o tráfico e consumo de drogas, e outras atividades ilícitas.
} 
escolar entre as crianças aumentado. O estudo propõe ainda que se as famílias recebessem subsídios equivalentes ao rendimento das crianças para que estas deixem o trabalho e frequientem a escola, o trabalho infantil poderia ser eliminado.

O simples cumprimento da legislação do salário mínimo já contribuiria para o combate ao trabalho infantil, uma vez que a demanda por este tipo de mão-de-obra (considerada menos produtiva que a de adultos) seria reduzida, e a demanda por trabalho adulto aumentada, elevando a renda da família. No entanto, esta política poderia ter o efeito perverso de diminuir o bem estar de crianças de famílias com número pequeno de adultos ou que têm o chefe ausente (Kassouf, 2002).

Segundo Medici \& Braga (1993), quando a questão social atinge elevadas proporções não pode ser enfrentada unicamente por meio de políticas sociais compensatórias, "cujo caráter imediatista ou emergencial não promove o advento de soluções de mudança estrutural na condição social de seus beneficiários imediatos”.

Basu (1999) nota que a melhor maneira de banir o trabalho infantil é tornando a frequiência escolar compulsória, pois "é mais fácil monitorar a presença na escola que a ausência no trabalho". Mesmo que escola e trabalho não sejam mutuamente exclusivos, o autor observa que pelo menos o trabalho em tempo integral será eliminado e a escolaridade obtida por estes indivíduos será maior, o que é obviamente desejável.

Segue-se então que políticas que combinem educação e renda seriam as mais indicadas para erradicar o trabalho infantil e combater a pobreza, dado que adultos com nível de escolaridade maior dão mais importância à educação, vendo nela a oportunidade de um futuro melhor para suas crianças, e incentivando-as a freqüentar a escola. Dessa forma, aumentar o engajamento escolar das crianças hoje geraria adultos com escolaridade maior no futuro e que fariam o papel de incentivadores de seus filhos no que se refere à educação, atacando uma das causas do ciclo de pobreza e promovendo uma mudança estrutural desta parcela da população. 


\subsubsection{Focalização versus universalização de programas sociais}

Uma das questões cruciais no desenvolvimento dos programas sociais diz respeito ao nível de cobertura, isto é, se uma família (ou um indivíduo) deve preencher certos requisitos para ser considerada potencial beneficiária do programa, ou se todos têm direitos iguais em relação a ele.

Em outras palavras, a discussão está em torno dos custos e benefícios de políticas públicas focalizadas em relação às políticas universais. No caso de políticas de combate à pobreza, a focalização é obtida por meio da verificação de acesso a recursos, ou seja, da verificação de pobreza ou meios (estes esquemas são conhecidos como means-tested).

Considera-se que um programa de alívio ou combate à pobreza utiliza um esquema de verificação de acesso a recursos quando a renda da pessoa é observada e a diferença entre a renda e a linha de pobreza dá origem, por exemplo, a uma transferência monetária direta de valor fixo (do tipo lump-sum). Quando o benefício está disponível para toda a população, pobre ou não, o programa é considerado universal (Besley, 1990).

No primeiro caso há um custo administrativo para testar e elegibilidade dos solicitantes, além dos custos pecuniários ou psicológicos de quem deve comprovar sua condição de pobreza para receber o benefício. Por outro lado, quando todos têm o mesmo direito a um benefício os recursos disponíveis podem indevidamente ser gastos com a população não-pobre.

Quando é feita a opção por programas que empregam a verificação da pobreza, mas a renda não é diretamente observada, a alternativa é utilizar alguma proxy baseada em informações intimamente ligadas à renda ou à riqueza, tais como bens de consumo duráveis, material de construção do domicílio, etc., produzindo um sistema de pontuação que classifique a família ou o indivíduo (Anuatti Neto, Fernandes \& Pazello, 2001).

Rocha (2000) observa que um sistema de pontuação que leve em conta renda (ou proxy de renda) e condições adversas pode ser ineficiente para selecionar famílias dentre um grupo homogêneo (ou seja, pode não ser indicado para diferenciar pessoas de 
um mesmo bairro pobre, que tem as mesmas dificuldades de acesso a serviços públicos), embora seja eficiente para selecionar indivíduos de regiões diferentes.

Besley (1990) ilustra o trade-off existente entre um esquema que utiliza a verificação de acesso a recursos e o benefício universal, por meio do conceito de "custo crítico da verificação de meios", que indica o custo incorrido pelo solicitante de um benefício que utiliza a verificação de meios que faria com que o benefício universal fosse preferido, admitindo que cada tipo de esquema seja representado por um indicador do nível de pobreza.

Assim, se os custos decorrentes de solicitar o benefício forem nulos, todos os pobres irão solicitá-lo, e a pobreza seria erradicada sob um esquema de verificação de meios. Da mesma forma, se estes custos forem iguais ao valor da linha de pobreza, não haverá mudança nos indicadores. No entanto, se o custo de solicitar o benefício estiver entre zero e a linha de pobreza pouco pode ser dito sobre o resultado final.

No entanto, pode-se inferir que o benefício universal será preferido ao que utiliza a verificação de acesso a recursos apenas quando os custos envolvidos na sua implementação e manutenção forem menores e a redução da pobreza for maior no primeiro caso que no segundo.

Devido principalmente à restrição orçamentária do poder público, a maior parte dos programas de combate à pobreza existente atualmente são focalizados e utilizam um sistema de pontuação que inclui outras variáveis além da renda observada para selecionar seus beneficiários.

Schultz (2001) argumenta que a grande desvantagem de um programa universal, como subsidiar preços agrícolas para aumentar a renda de produtores rurais pobres, é que não será direcionado ao pobre, e os produtores serão beneficiados proporcionalmente ao tamanho de sua propriedade. Além disso, em casos de complemento de renda ou suporte de preços nada garante que o beneficiário irá investir os recursos adicionais no aumento de capital humano, e o programa poderia até diminuir o incentivo para aumentar a renda futura e diminuir a dependência do auxílio do poder 
público $^{8}$.

Outro aspecto importante no debate entre focalização e universalização de políticas sociais refere-se ao conceito de justiça social. Definir se o mais justo é que todos tenham o mesmo direito em relação aos recursos públicos, sem discriminação pela renda, ou se o mais justo é que os mais pobres tenham acesso prioritário, se não restrito, a estes recursos esbarra numa questão de julgamento de valores morais e éticos.

É possível argumentar, por exemplo, que o tempo necessário para solicitar um benefício represente um custo de oportunidade muito maior para um rico do que para um pobre em relação ao valor deste benefício, e como conseqüência o rico "naturalmente" não concorreria com o pobre num programa social. Ou seja, não é necessário impedir que um indivíduo que não precisa do recurso público seja potencial beneficiário porque ele não vai solicitá-lo.

Por outro lado, se os recursos disponíveis são escassos, atender os mais pobres primeiro pode ser considerada uma forma mais coerente ou justa de ordenar os beneficiários.

De toda maneira, é uma questão polêmica e está fora do escopo deste trabalho a pretensão de definir justiça social ou mesmo julgar questões éticas ou normativas de tal natureza.

\subsubsection{A proibição legal}

A proibição legal do trabalho infantil é largamente utilizada, mas só é eficaz quando o salário de reserva dos indivíduos for maior que o salário de mercado. Basu \& Van (1988) argumentam que embora o mais comum seja a aprovação de leis proibitivas, ao entrar em vigor estas se tornam desnecessárias, uma vez que provocam uma redução

\footnotetext{
8 Schultz (2001) afirma que "em particular, programas de redução da pobreza do tipo means-tested reduzem o tempo que os beneficiários dedicam ao trabalho remunerado, porque seus ganhos são efetivamente taxados a uma taxa maior que o dos não beneficiários, pois eles também perdem as transferências do governo conforme seus rendimentos aumentam".
} 
na oferta de trabalho, que por sua vez leva a um aumento nos salários dos adultos ${ }^{9}$. Conseqüentemente, a renda ou riqueza familiar aumenta, as crianças não são mais enviadas ao trabalho, e o mercado estará em equilíbrio sem a participação da mão-deobra infantil, como visto em seção anterior. Entretanto, os próprios autores reconhecem que a validade desta análise depende do tamanho e do nível de desenvolvimento do país em questão.

No Brasil, por exemplo, até 1998 o trabalho de pessoas menores de 14 anos era proibido, salvo na condição de aprendiz. Em 1999 foi aprovado o decreto legislativo no. 179, que "aprova os textos da Convenção 138 e da Recomendação 146 da OIT sobre a Idade Mínima de Admissão ao Emprego, adotadas em junho de 1973, em Genebra”, e aumenta a idade mínima para ingresso no mercado de trabalho para 16 anos, visando reduzir a incidência de trabalhadores adolescentes e conseqüentemente aumentando sua permanência na escola. Entretanto, os dados brasileiros mostram que milhões de crianças e adolescentes estão trabalhando, muitas vezes sem receber salários.

Ferro \& Kassouf (2003) observam dois efeitos distintos da elevação da idade mínima para entrada no mercado de trabalho para os brasileiros de 14 e 15 anos, que em última análise foram excluídos do mercado formal a partir de 1999: aqueles cujo salário de reserva era maior que o salário de mercado praticado após o Decreto 179 deixaram de trabalhar; por outro lado aqueles cujo salário de reserva era menor que o de mercado continuaram a exercer atividades laborais, mesmo havendo queda na remuneração, na jornada e na qualidade dos postos de trabalho. Mesmo entre os indivíduos que já não poderiam estar no mercado de trabalho antes da promulgação desta lei - isto é, entre aqueles que tinham menos de 14 anos antes de 1999 - observa-se uma elevada proporção de economicamente ativos.

É possível concluir então que a simples existência de uma lei que proíbe o trabalho infantil, embora seja necessária, não é suficiente para que ele deixe de existir por si só. Para eliminá-lo, é preciso também incentivar as famílias a enviar suas crianças

\footnotetext{
${ }^{9}$ Quando os salários são rígidos, haveria uma diminuição no desemprego.
} 
para a escola ao invés de enviá-las ao trabalho, e dar condições financeiras e de infraestrutura para que isso ocorra.

\subsubsection{Políticas de transferência de renda e incentivo à educação}

Admitindo que o fator predominante para que os pais decidam inserir seus filhos no mercado de trabalho é a pobreza, são formuladas políticas de transferência de renda. Como já discutido anteriormente é uma medida simplista por não levar em consideração características sócio-culturais, e também por não promover alterações estruturais na população alvo.

Quando outras variáveis que não a riqueza ou a renda da família são levadas em conta, percebe-se que somente a transferência monetária é insuficiente, pois em algumas sociedades ${ }^{10} \mathrm{o}$ trabalho precoce pode ser considerado educativo, ou a educação formal pode não ser considerada atrativa, entre outros fatores, e esta medida pode ter apenas caráter compensatório.

Admitindo ainda que a educação dos pais exerce influência sobre a educação dos filhos (Kassouf, 2001), o incentivo à demanda por educação formal faria com que os indivíduos dessem progressivamente mais valor à escolaridade, e que com o tempo e o passar das gerações este tipo de política torne-se desnecessário, pois teria provocado uma mudança estrutural no comportamento dos indivíduos.

A partir daí foram desenvolvidos programas sociais combinados ou condicionados: transferem renda admitindo que o fator predominante é a pobreza, mas o benefício é atrelado a algum comportamento desejado, como procurar atendimento de saúde regularmente, fazer exames periódicos, freqüentar o sistema formal de ensino ou agências de emprego e qualificação, etc. Tais programas são classificados também como subsídios à demanda por serviços públicos, e parte de seu sucesso está condicionado a uma política complementar de investimentos na oferta destes serviços (Camargo \&

\footnotetext{
${ }^{10}$ Entende-se como 'sociedades' países, regiões de um país, cidades, comunidades e até mesmo parcelas da população que tenham características semelhantes.
} 
Ferreira, 2001).

Agrupados sob a sigla MISA - Minimum Income for School Atendance - os programas que têm o objetivo de aliviar a "pobreza atual" por meio de transferência de renda, e combater a "pobreza futura" condicionando a transferência ao engajamento no sistema formal de ensino ${ }^{11}$ apresentam algumas diferenças em seu design, o que altera, por exemplo, o volume de gastos necessários e a população atingida. Serão descritas a seguir as experiências de Bangladesh e do México, bem como os programas brasileiros os chamados Bolsa Escola.

\subsubsection{Experiências internacionais}

O programa Food-for-Education (FFE) foi implementado pelo Governo da República Popular de Bangladesh em 1993 como projeto piloto de larga escala, em substituição a um programa de subsídio à alimentação focalizado na população pobre que havia sido extinto.

O objetivo central do FFE era o desenvolvimento no longo prazo do capital humano, incentivando o engajamento escolar das crianças de famílias pobres por meio da transferência de alimentos, como grãos ou farinhas.

A racionalidade do programa residia no fato de que grande parte da população era estruturalmente pobre, mal-nutrida, e as crianças não freqüentavam a rede formal de ensino ou porque a família não podia comprar material escolar, roupas e livros, ou porque o trabalho da criança na agricultura ou no domicílio era imprescindível para a sobrevivência da família.

Assim, a doação de alimentos permitia que os beneficiários deixassem de gastar uma parte de seu orçamento com alimentação, ou então vendessem sua cota utilizando o dinheiro para satisfazer outras necessidades do domicílio, desde que suas crianças estivessem regularmente matriculadas e assistindo as aulas - o que, por sua vez, impedia

\footnotetext{
${ }^{11}$ Uma vez que uma das causas do ciclo da pobreza é o baixo nível de escolaridade, que se reflete em baixos salários futuros e, portanto, pobreza futura.
} 
que as crianças pobres perpetuassem o ciclo de pobreza por não ter oportunidades melhores no futuro devido a seu baixo nível educacional.

De forma geral, é um programa similar aos de Bolsa Escola brasileiros, mas a transferência é feita em bens e não em dinheiro, e é única para a família, independentemente do número de crianças assistidas em cada domicílio. Além disso, enquanto o Food for Education é voltado para a população rural, o programa brasileiro se aplica para todas as áreas de domicílio.

A iniciativa mexicana de complementação de renda condicionada a investimentos em capital humano tem uma escala muito mais ampla que a brasileira porque tenta melhorar não somente o desempenho escolar como também o desenvolvimento nutricional de seus beneficiários.

Concebido para atender famílias carentes, o Progresa está em vigor desde 1997 e seu orçamento representa $1 \%$ do PIB, e intervém tanto na demanda como na oferta dos serviços públicos educacionais e de saúde.

As famílias beneficiadas não podem participar de outros programas de combate à pobreza, e devem manter seus filhos em idade escolar matriculados e com freqüência mínima, ou mesmo matriculados em telecursos. Além disso, devem comparecer regularmente aos postos de saúde para medição de altura e peso e averiguação do estado geral de saúde das crianças, e os responsáveis devem assistir a palestras sobre higiene e saúde.

Quando todos os deveres são cumpridos, cada família recebe 70 pesos por criança na escola primária e 255 pesos por criança na secundária ${ }^{12}$, sendo que o valor da bolsa é um pouco maior para meninas do curso secundário. Ainda há auxílios para compra de material escolar e de alimentos, e no último caso não importa a quantidade de crianças da família. Assim, algumas famílias chegam a receber 650 pesos mensais, o equivalente ao salário mínimo mexicano ${ }^{13}$.

\footnotetext{
${ }^{12} \mathrm{O}$ valor total deste tipo de bolsa não pode exceder 525 pesos.

${ }^{13}$ Valores e dados de 1999.
} 
As diferenças nos valores das bolsas devem compensar as diferenças no custo de oportunidade das crianças e diminuir a diferença de escolaridade entre os sexos, e como a bolsa é dada por criança, o descumprimento dos deveres por parte de uma delas não impede o recebimento das outras bolsas destinadas àquela família.

Também são previstos no programa auxílios não pecuniários, como complementos de nutrientes e remédios para gestantes e crianças menores de dois anos.

Para monitorar o programa, são selecionados membros da comunidade que também ajudam a esclarecer dúvidas e a identificar potenciais beneficiários.

As intervenções do lado da oferta dos serviços ocorrem por meio da capacitação de profissionais e melhoria de equipamentos disponíveis, tanto na área de educação como na de saúde. Apesar disso, o programa é vulnerável a deficiências na oferta, pois justamente as regiões mais necessitadas são as que possuem pior infraestrutura de serviços públicos, o que também é observado no caso brasileiro.

Outras críticas foram feitas ao programa, e dizem respeito tanto ao seu design quanto a sua operacionalização. Primeiro, o programa poderia incentivar famílias pobres a se tornarem mais numerosas, já que o benefício é proporcional ao número de crianças. Além disso, seria possível atingir o mesmo objetivo com bolsas de menor valor. Segundo, as exigências são tantas que podem desincentivar o acesso ao programa, e até mesmo impossibilitar famílias que vivem em regiões remotas e de difícil acesso de cumprir as exigências para o recebimento das bolsas.

As principais diferenças entre os casos mexicano e brasileiro é que este não prevê aumento no valor das bolsas com o aumento da idade, nem diferenciação entre os sexos ou complementação nutricional e acompanhamento de crianças fora da idade escolar. Neste sentido, o Progresa é considerado muito mais amplo, apesar de ter sido construído a partir de objetivos semelhantes.

\subsubsection{Os programas de Bolsa Escola no Brasil}

No Brasil, três iniciativas têm destaque quando se trata de programas de renda 
mínima vinculada à educação como forma de erradicar o trabalho infantil: o programa de Renda Mínima de Campinas, o Bolsa Escola do Distrito Federal e o Programa de Erradicação do Trabalho Infantil (PETI). Os dois primeiros deram origem ao programa Bolsa Escola Federal, que é atualmente um dos mais abrangentes programas sociais brasileiros, e o PETI destaca-se por atuar especificamente onde o problema é mais grave, ou seja, nas regiões em que há maior incidência de trabalho infantil perigoso.

O PETI foi implementado em 1996 nas áreas rurais do Brasil, prioritariamente nas que apresentavam elevado índice de crianças engajadas nas piores formas de trabalho. Como a implantação em nível nacional seria muito cara, o governo optou por iniciar o programa somente onde as piores formas foram identificadas. Assim, o PETI atendeu inicialmente 1.500 crianças que trabalhavam nos fornos de carvão e na colheita da erva-mate de 14 Municípios do Estado do Mato Grosso do Sul (Ministério da Assistência e Promoção Social, 2003).

São potencialmente beneficiárias do PETI as famílias que têm renda per capita abaixo de meio salário mínimo e crianças entre sete e catorze anos entre seus componentes. O montante do benefício recebido é o mesmo para cada família ${ }^{14}$, independente do número de crianças inscritas, isto é, a família pode inscrever alguns de seus filhos no programa, especializando-os em educação, e não inscrever outros, especializando-os em trabalho.

A principal diferença entre os dois programas brasileiros é que o PETI exige que os responsáveis pela criança comprometam-se formalmente a tirá-la do trabalho, e que a escola deve estender o período de permanência dos beneficiários do programa por meio da chamada Jornada Ampliada.

A Jornada Ampliada é implementada (e custeada) pelo município, e seu principal objetivo é limitar o tempo da criança que ficaria disponível para o trabalho, mesmo que os pais tenham se comprometido formalmente a não inserí-las no mercado.

A criança passa o dia na escola, envolvida nas atividades socioeducativas

\footnotetext{
${ }^{14}$ No entanto, o valor do benefício era diferente para cada Estado.
} 
promovidas. O conteúdo da Jornada Ampliada não foi especificado no programa, por isso essas atividades variam bastante entre as localidades, mas todas as crianças beneficiárias ou não - podem participar delas.

Assim, o PETI tem efeitos diretos sobre o trabalho infantil porque para participar a criança é obrigada a deixar o emprego, e efeitos indiretos sobre a população não beneficiária, embora estes últimos sejam ambíguos. Por exemplo, as crianças não beneficiárias podem ser incentivadas a trabalhar uma vez que tornar a mão-de-obra infantil escassa eleva os salários, ou incentivadas a permanecer na escola porque podem participar da Jornada Ampliada mesmo não estando inscritas no programa (Yap, Sedlacek \& Orazem, 2001).

Atualmente o programa atende cerca de 800 mil meninos e meninas, em 237 municípios de 14 estados, contando com um orçamento de mais de 300 milhões de reais.

Pioneiros em programas sociais de transferência condicionada de renda, o Bolsa Escola no Distrito Federal e o Renda Mínima em Campinas foram implantados em 1995 e consistiam no pagamento de uma "mensalidade" para cada família que mantivesse seus filhos na escola.

Os resultados positivos fizeram com que o Bolsa Escola fosse adotado por diversos municípios de vários estados brasileiros, e entre 1995 e 1999 Amapá, Mato Grosso do Sul, Alagoas, Minas Gerais, Rio de Janeiro, Goiás e Acre implementaram variações dos programas pioneiros em algumas de suas cidades.

O programa se transformou num dos mais amplos programas sociais do mundo em 11 de abril de 2001, quando foi sancionada a Lei no. 10219, que instituiu o Bolsa Escola em âmbito federal. Por meio desta lei, o governo federal passou a apoiar programas municipais ${ }^{15}$ de garantia de renda mínima, desde que associados a "ações socioeducativas de apoio aos trabalhos escolares, de alimentação e de práticas

\footnotetext{
${ }^{15} \mathrm{O}$ programa municipal deve ser instituído legalmente e direcionado à população de baixa renda, o termo de adesão ao Bolsa Escola deve ser aprovado pelo legislativo, e deve ser formado um conselho social de acompanhamento do programa.
} 
desportivas e culturais em horário complementar ao das aulas" que de alguma forma incentivem a permanência da criança na escola durante o maior tempo possível.

Da forma como o programa federal foi criado, os municípios que já tinham seus próprios programas de transferência de renda vinculados à educação puderam manter seus benefícios, aumentando o número de beneficiados ou o valor das bolsas, de acordo com suas necessidades, caso aderissem ao Bolsa Escola Federal. Na maior parte dos casos, entretanto, as bolsas existentes são apenas as concedidas pela União, ficando como responsabilidade do município a gestão do programa, dado que os municípios mais necessitados são os que possuem menos recursos para este tipo de intervenção social. As regras para obtenção do benefício também podem ser consideradas uniformes entre os municípios brasileiros.

As famílias que têm direito ao benefício são as que possuem membros em idade escolar (entre seis e quinze anos) devidamente matriculados e com freqüência maior ou igual a $85 \%$. Neste ponto o programa federal é igual aos programas municipais implementados anteriormente.

Entretanto, enquanto o programa do Distrito Federal pagava uma mensalidade única para a família, independente do número de crianças, o programa nacional prevê um pagamento por criança e limita o número de crianças beneficiárias de uma mesma família de modo que não haja incentivo para aumento na taxa de fecundidade entre a população alvo. Segundo a regra em vigor atualmente, são concedidas no máximo três bolsas mensais por família elegível, independentemente do número de crianças em idade escolar entre seus componentes. Em outras palavras, se numa família que preencha todos os requisitos para obtenção do benefício houver quatro crianças em idade escolar, apenas três delas poderão ser inscritas no programa ${ }^{16}$.

Resumindo, quando todos os requisitos são preenchidos, a União paga,

\footnotetext{
${ }^{16}$ Outro ponto importante das regras do Bolsa Escola é que "é vedada a inclusão nos programas referidos nesta Lei, por parte dos Municípios, de famílias beneficiadas pelo Programa de Erradicação do Trabalho Infantil, enquanto permanecerem naquela condição. (art.7)", embora a criança possa participar de outros programas municipais.
} 
diretamente ao beneficiário por meio de cartões magnéticos, $\mathrm{R} \$ 15,00$ (quinze reais) por criança, até o limite máximo de três crianças por família que tem renda per capita inferior a $\mathrm{R} \$ 90,00$ (noventa reais).

O pagamento é efetuado preferencialmente às mães, até como forma de envolvê-las no processo de aprendizado da criança e estimular a auto-confiança da mulher, colaborando inclusive para tornar as relações da família mais igualitárias. Esse mecanismo é também adotado pelo mexicano Progresa.

Os objetivos centrais do Programa Bolsa Escola são descritos por meio de quatro itens, não necessariamente na ordem de importância: i) aumentar a escolaridade e conseqüentemente reduzir a pobreza no longo prazo; ii) reduzir a pobreza no curto prazo; iii) reduzir a incidência de trabalho infantil; e iv) atuar como uma espécie de rede de seguridade.

O primeiro deles é direto: conforme as crianças se tornam mais educadas, suas chances futuras no mercado de trabalho serão melhores, assim como seus salários, e estes indivíduos incentivarão seus filhos a estudar, diminuindo a pobreza no longo prazo.

O segundo objetivo age como uma política social compensatória: se os pobres estudam menos porque se deparam com restrições de crédito e a renda das crianças é fundamental para a sobrevivência da família, o pagamento de uma quantia em dinheiro atua como espécie de "alívio" da situação de pobreza, que permite o ingresso destas crianças na escola.

O terceiro objetivo não é expresso claramente nas regras do programa, que ao contrário do PETI, não exige que os responsáveis assinem um termo comprometendo-se a retirar a criança do trabalho. Porém, considerando que a criança obrigatoriamente terá seu tempo livre reduzido, admite-se que ela naturalmente deixará o mercado de trabalho. Além disso, o valor da bolsa substituiria, pelo menos parcialmente, a contribuição da criança para a renda da família, e compensaria o custo de oportunidade da criança em relação aos ganhos no mercado de trabalho. Entretanto este efeito pode ser ambíguo, 
pois a criança pode continuar trabalhando, reduzindo o tempo de lazer ou aquele que teria para o estudo em casa, sem deixar de freqüentar a escola.

Finalmente, o Bolsa Escola pode ser visto como uma rede de seguridade, já que seus beneficiários são famílias muito pobres, extremamente suscetíveis a todo tipo de choques: econômicos, conjunturais e idiossincráticos.

As principais críticas em relação ao modelo adotado são: i) o programa brasileiro não leva em conta o aumento no custo de oportunidade das crianças de acordo com a idade, mantendo o mesmo valor da bolsa no ensino básico e fundamental; ii) como exige uma contrapartida municipal, as regiões mais necessitadas não são atendidas, pois são incapazes de financiar um programa social desta natureza; iii) famílias em que todas as crianças são menores de seis anos são desclassificadas, mesmo que extremamente pobres; e iv) como o programa não exige um número mínimo de semestres ou períodos letivos freqüentados, os pais podem tirar as crianças que trabalham em atividades sazonais da escola em determinados períodos, e retorná-las ao programa em seguida, como forma de aumentar seus ganhos anuais, mesmo que isso prejudique o acúmulo de capital humano daquela criança.

Apesar das críticas o programa tem sido bem avaliado principalmente no que se refere ao aumento do engajamento escolar, apesar de ser complicado avaliar a qualidade da educação recebida pelas crianças (World Bank, 2001; Rocha, 2000; Sabóia \& Rocha, 2002).

Prova deste sucesso é que o Brasil colaborou na implementação do Programa no Equador em 1999 e em países africanos, como São Tomé e Príncipe e Moçambique. Também houve cooperação técnica brasileira na implantação do Bolsa Escola em El Salvador e na Guatemala.

Atualmente os programas de Bolsa Escola estão presentes em mais de 5.500 municípios, atendendo cerca de 5,1 milhões de famílias pobres que recebem auxílio financeiro para manter seus filhos na escola - mais de 6,4 milhões de crianças. 


\subsection{Avaliação de políticas sociais}

Já no final dos anos 70, Ferber \& Hirsch (1978) afirmavam que "os economistas há muito tempo deparam-se com o problema de como medir os efeitos de mudanças em variáveis de políticas no comportamento das unidades econômicas”. Os impactos das políticas sociais poderiam ser obtidos por meio de técnicas estatísticas e modelos econométricos que simulem populações artificiais (técnicas nãoexperimentais), ou utilizando experimentos controlados, parecidos com os utilizados em biologia ou agricultura.

Os experimentos sociais são geralmente utilizados para medir o impacto de programas sociais novos ou potenciais, e até mesmo para ajudar a decidir que variáveis (ou que magnitude devem ter tais variáveis) produzem os melhores resultados.

Entretanto, o uso do mundo real como laboratório de experimentação envolve dificuldades metodológicas e questões éticas importantes. No primeiro caso, o custo e o tempo exigidos num experimento são justificáveis apenas quando os custos da implementação direta for tão alto que valha a pena "testar para ver se dá certo" antes. Em segundo lugar, manipular e interferir nos recursos e no estilo de vida das pessoas pode ser tão prejudicial para estes indivíduos que não justifique o experimento.

Supondo, por exemplo, que uma família concorde em receber um complemento de renda durante cinco anos para participar de um experimento, mas que no decorrer do tempo assuma que o aumento dos recursos é permanente, quando terminar a pesquisa estes indivíduos podem ter um padrão de vida que são incapazes de sustentar sem o complemento. Embora seja ruim para a família o resultado de uma pesquisa sobre o comportamento "econômico" do indivíduo, sob o ponto de vista do experimento até seria melhor quando isso acontecesse porque representaria o comportamento verdadeiro, ou seja, aquele que pode ser esperado quando o aumento na renda é permanente. Ética e moralmente, porém, são consequiências absolutamente indesejáveis (Ferber \& Hirsch, 1978).

Da mesma forma, a ética de um programa experimental que priva uma parte da 
população de seus benefícios para que seja formado um grupo de controle pode ser questionada.

Por outro lado, quando a teoria econômica ainda não foi capaz de explicar determinado fenômeno, ou até mesmo quando os recursos disponíveis são escassos e a abrangência de uma política generalizada extremamente grande, a experimentação social é capaz de dar grandes contribuições.

A despeito da discussão ética envolvida na experimentação em si, vários estudos foram feitos comparando técnicas experimentais e não experimentais para avaliar políticas sociais. São estudos que utilizam as duas técnicas em dados experimentais, e se a diferença dos resultados é significativa os métodos econométricos ou estatísticos não são considerados consistentes.

Friedlander \& Robins (1995) avaliam os métodos não experimentais mais utilizados para estimar os efeitos de programas sociais. Um destes métodos consiste em estimar os efeitos de políticas de uma localidade, comparando estes indivíduos com pessoas de outras localidades, onde a política em questão não existe. A outra abordagem compara o comportamento de beneficiários e não beneficiários de uma mesma área onde um programa é implementado. Os autores notam que a principal dificuldade encontrada quando técnicas não experimentais são utilizadas é a definição de um grupo de controle adequado.

Os resultados encontrados mostram que os estimadores obtidos por técnicas não experimentais foram bem diferentes dos gerados por métodos experimentais, utilizandose o mesmo conjunto de dados. Mostram também que é arriscado comparar o comportamento de indivíduos que moram em localidades diferentes.

No primeiro caso, em que são analisados indivíduos de localidades diferentes, isso pode ocorrer devido a fatores ambientais que não são controlados. Mesmo quando são aplicadas técnicas estatísticas de matching e testes de especificação, os resultados do método não experimental não apresentam grandes melhoras. Quando os grupos de controle e tratamento pertencem à mesma localidade os resultados são melhores que no 
primeiro caso, porém embora as discrepâncias sejam menores, algumas diferenças importantes em relação à análise experimental persistem. Neste caso, a utilização de comparações “cross-cohort” ou “cross-site”, que aproximam as amostras no espaço e no tempo, geram ajustes melhores do que os obtidos por matching e testes de especificação.

Assim, Friedlander \& Robins (1995) encontram indícios de que estudos desta natureza devem no mínimo utilizar localidades similares às de tratamento como grupo de controle quando não for possível obter amostras da mesma localidade. Mesmo assim, os resultados obtidos por métodos experimentais serão sempre melhores que os estimados por técnicas não experimentais.

A importância de métodos não experimentais confiáveis deve-se ao fato de que pode haver limitações nos dados disponíveis, ou o pesquisador pode ser contra experimentos, ou até a própria natureza do programa impede que sejam definidas amostras aleatórias, o que não permite o uso de técnicas experimentais, que pressupõem amostras verdadeiramente aleatórias (Friedllander \& Robins, 1995).

Heckman \& Smith (1995) argumentam ainda que tanto a abordagem experimental quanto a econométrica oferecem vantagens de acordo com os objetivos propostos pelo pesquisador, e que a credibilidade das análises depende das pressuposições e da qualidade dos dados utilizados. Assim deve-se tentar, antes de elaborar modelos estruturais mais complicados que sejam mais adequados aos dados, verificar se o programa social tem algum impacto sobre seus participantes, e quais seriam estes impactos. Segundo os autores, a questão central é "se experimentos sociais aleatórios dão respostas seguras às questões básicas sobre avaliação de programas", ou seja, se são realmente necessários.

Há ainda duas abordagens distintas para avaliar os efeitos de políticas sociais, principalmente as focalizadas. A abordagem ex-post consiste em comparar beneficiários observados com não beneficiários, possivelmente controlando a seleção dentro do primeiro ou do segundo grupo quando amostras verdadeiramente aleatórias são disponíveis. Já na avaliação ex-ante os efeitos do programa são simulados segundo um 
modelo comportamental especificado para a família ou domicílio, e dentre estes métodos, podem ser utilizados modelos de simulação aritmética simples ${ }^{17}$ ou modelos mais complexos, que incluem respostas comportamentais dos beneficiários (Bourguignon, Ferreira \& Leite, 2002).

Como têm objetivos diferentes, as avaliações ex-ante e ex-post são consideradas complementares ao invés de substitutas. O primeiro caso permite simular mudanças no impacto do programa devido a alterações no seu design (pontuação, limites de renda e valor das transferências, por exemplo), colaborando para que testes sejam feitos antes de definir uma regra. O segundo é considerado uma avaliação "real" porque utiliza os dados observados para responder à questão de "como estariam estes indivíduos se o programa não existisse?" a partir da construção de grupos de controle.

Resumindo, existem várias formas de se avaliar programas sociais. Os programas podem ter caráter experimental, permitindo então o uso de técnicas econométricas e estatísticas ou de métodos experimentais. Além disso, em avaliações exante são utilizados métodos não experimentais, enquanto em avaliações ex-post ambos podem ser aplicados. Em alguns casos, no entanto, só é possível fazer avaliações por meio de técnicas não experimentais.

Nas próximas seções serão discutidas as técnicas utilizadas para avaliar os programas sociais citados anteriormente.

\subsubsection{Avaliação de programas de renda mínima vinculada à educação}

Grande parte da literatura internacional sobre avaliação de políticas sociais condicionadas trata da experiência mexicana - o Progresa - que foi implementado de forma especial. Na primeira fase da implementação foram escolhidas aleatoriamente localidades que participariam do programa, servindo como grupo de tratamento, enquanto localidades semelhantes tiveram o papel de grupo de controle, recebendo os

\footnotetext{
17 Estes modelos aplicam as regras oficiais para determinar se a família é qualificada, e o total de transferências a serem feitas de acordo com pesquisas de domicílio típicas.
} 
benefícios somente a partir do segundo ano.

Esta característica experimental do Progresa permitiu que seus efeitos sobre o engajamento escolar no curto prazo fossem avaliados de forma bem mais precisa e simples do que em outros programas, bastando comparar as diferenças entre os grupos de controle e tratamento antes e depois do programa [Schultz (2001)].

Schultz (2001) avalia os impactos do Progresa no engajamento escolar fazendo uma análise em dois estágios. O primeiro utiliza a técnica de diferenças-em-diferenças entre as crianças do grupo de controle e de tratamento, e os impactos estimados dos controles podem ajudar a avaliar políticas alternativas, enquanto interações entre características das famílias e efeitos dos programas podem ser estimadas para testar se os efeitos no grupo de tratamento são heterogêneos.

O segundo estágio consiste em um modelo comportamental das crianças em idade escolar, incluindo variáveis de controle como qualidade e acesso à escola, custo de oportunidade do tempo da criança, educação dos pais. Sob certas condições, o modelo próbite é candidato a descrever a decisão de engajamento escolar $\left(S_{i}\right)$, e pode-se expressar a aproximação linear do modelo estimado como:

$$
S_{i}=\alpha_{0}+\alpha_{1} P_{i}+\alpha_{2} E_{i}+\alpha_{3} P_{i} E_{i}+\sum_{k=1}^{K} \gamma_{k i} C_{k i}+\sum_{j=1}^{J} \beta_{j} X_{j i}+e_{i} \quad i=1,2 \ldots, n
$$

em que $i$ representa cada criança e $n$ o número total de crianças de cada cross-section; $P$ assume o valor 1 quando a localidade pertence ao grupo de tratamento e zero caso contrário; $E$ designa a criança elegível, e assume o valor 1 quando a família é pobre. $C_{k}$ assume o valor 1 quando a criança completa exatamente $k$ anos de estudo ${ }^{18}, \mathrm{k}=0,1, . ., 9$, e $X_{j i}$ são as $j$ demais características de cada criança $i$.

Já os efeitos de longo prazo são captados numa equação que representa as $i$ cross-sections ao longo do tempo, que foi estimada separadamente para meninos e

\footnotetext{
${ }^{18}$ Como a criança apenas se qualifica para a série $\mathrm{k}+1$ quando completa a anterior, e como apenas é elegível quando está matriculada, a variável $C$ foi incluída para captar o efeito das matrículas, que variam entre as séries.
} 
meninas, dado que os parâmetros diferem significativamente entre os gêneros, principalmente nas séries mais elevadas.

Schultz (2001) conclui que as diferenças pré-programa não foram significativas, o que sugere que a implementação experimental atingiu seus objetivos. Além disso, o programa consegue focalizar corretamente os pobres, tanto geográfica quanto economicamente, e há evidências de que o pagamento das transferências foi efetivo em reduzir a desigualdade econômica e de escolaridade nas localidades que tinham o Progresa, quando comparadas às localidades que não tinham o Progresa.

Para avaliar o impacto do programa Food-for-Education no trabalho infantil Ravallion \& Wodon (2000) assumem que a função que representa a oferta de trabalho (L) para cada criança $i$ é dada por:

$$
L_{i}=\eta_{i}+\alpha F F E_{i}+\hat{\mathbf{a}}^{\prime} \mathbf{X}_{i}+\varepsilon_{i}
$$

onde $c ̧$ é o valor crítico de trabalho exercido por cada criança ${ }^{19}, F F E$ é a quantidade de comida recebida do programa, å é o erro e o vetor $\mathbf{X}$ inclui características da família e do indivíduo, como a escolaridade dos pais, a idade da criança e a religião a que pertence, e características da região em que a criança mora, como acesso e qualidade da escola.

A probabilidade de a criança estar na força de trabalho é dada pela equação (3) onde $F$ é a função de distribuição de $a$ :

$$
\operatorname{Pr}\left(L_{i}>\eta_{i}\right)=F\left(\alpha F F E_{i}+\hat{\mathbf{a}}^{\prime} \mathbf{X}_{i}\right)
$$

Foram estimados dois modelos próbite, um para meninos e outro para meninas entre cinco e dezesseis anos. A variável binária assume o valor um quando a criança trabalha, e zero quando não trabalha.

Além disso, a demanda por educação foi modelada pelos métodos tradicionais e o engajamento escolar estimado através do modelo próbite, e uma outra equação especificada para estimar a participação da localidade no programa:

\footnotetext{
${ }^{19}$ Os autores consideram que a criança está na força de trabalho se a quantidade de atividades exercidas excede este valor crítico.
} 


$$
F F E_{i}=\gamma F F E V_{i}+\mathbf{c}^{\prime} \mathbf{X}_{i}+v_{i}
$$

onde FFEV é uma variável binária que assume o valor um se o domicílio pertence a uma localidade atendida pelo programa e zero caso contrário.

Ravallion \& Wodon (2000) argumentam que o efeito do subsídio à educação sobre o trabalho infantil é em princípio ambíguo, já que o tempo dedicado ao estudo pode ser subtraído daquele que anteriormente era dedicado ao lazer e não ao trabalho. Os dados mostraram que o subsídio tinha um forte efeito positivo na freqüência escolar, assim como um efeito negativo no trabalho infantil. Entretanto, o decréscimo no trabalho infantil responde por uma pequena parte do aumento do engajamento escolar, o que sugere que os pais substituem educação por lazer ou outras atividades, mas não por trabalho, a fim de reduzir o impacto nos rendimentos do trabalho das crianças.

Yap, Sedlacaek \& Orazem (2001) avaliaram os impactos do PETI construindo grupos de tratamento e controle a fim de comparar engajamento e progresso escolar, trabalho, trabalho perigoso e jornada, entre crianças de domicílios participantes e não participantes do programa. Os autores delimitaram uma amostra com grupo de controle e tratamento dado que o programa foi implementado progressivamente em regiões semelhantes, e a estratégia adotada de entrevistar as famílias beneficiárias e nãobeneficiárias permitiu que os dados fossem obtidos respeitando a amostra definida e evitando a possibilidade de os coeficientes estimados serem viesados.

Assim, alguns municípios de Pernambuco, Bahia e Sergipe, que foram escolhidos para as primeiras experiências do $\mathrm{PETI}^{20}$, foram também selecionados para a avaliação proposta pelos autores.

Como havia diferenças no programa entre os estados participantes, a avaliação foi realizada para cada um deles separadamente. Foram recolhidos, em cada estado, dados de seis municípios, que foram divididos em dois grupos: i) o grupo de tratamento, que correspondia a três municípios participantes do programa; e ii) um grupo de

\footnotetext{
${ }^{20}$ A Bahia foi escolhida pela presença de crianças na cultura de sisal, Sergipe por causa do trabalho na indústria pesqueira e Pernambuco por empregar crianças na produção de cana-de-açúcar.
} 
controle, constituído de três municípios similares ao do primeiro grupo, mas que não participavam do $\mathrm{PETI}^{21}$.

De cada município foram escolhidos aleatoriamente 200 domicílios que tinham pelo menos uma criança com idade entre sete e catorze anos para compor a amostra. Então foram recolhidas informações sobre a criança, seus pais e o domicílio, e em domicílios que participavam do PETI também foram questionados o número de crianças inscritas e o primeiro ano de participação. Além disso, a análise concentrou-se nos domicílios mais pobres, excluindo da amostra aqueles que eram considerados muito ricos para participar do programa ${ }^{22}$.

Os domicílios de cada município foram subdivididos em dois grupos distintos. O primeiro (grupo A) incluía os domicílios participantes. O segundo (grupo B) agrupava os domicílios que não quiseram participar, e os que quiseram e não foram qualificados.

Em seguida os grupos dos domicílios participantes foram também subdivididos, uma vez que nem todas as crianças do domicílio precisavam ser inscritas no programa. Assim, o grupo A1 continha as crianças inscritas dos domicílios participantes, enquanto o grupo A2 reunia as crianças não inscritas dos domicílios do grupo A.

Em seguida, estimou-se uma equação próbite para verificar se os domicílios dos grupos A e B eram estatisticamente iguais, mas esta hipótese foi rejeitada e conseqüentemente o grupo B não poderia ser utilizado como controle do grupo A. Um terceiro conjunto (grupo C) foi formado com os domicílios qualificados, mas que não seriam beneficiados porque estavam em municípios não participantes, representando o controle verdadeiro.

Com base na análise dos dados amostrais, os autores concluíram que a melhor forma de avaliar os impactos do PETI nos rendimentos das famílias seria por meio de três especificações, utilizando variáveis binárias: i) impacto em crianças do PETI contra

\footnotetext{
${ }^{21}$ Na Bahia e no Sergipe os municípios do grupo de controle haviam optado por participar do PETI, mas a implantação ainda não havia ocorrido; em Pernambuco foram escolhidos municípios que optaram inicialmente por não participar do programa.

${ }^{22}$ A população excluída representa entre 6 e $10 \%$ da amostra, dependendo do município.
} 
crianças de outros municípios contra o grupo de controle; ii) impacto nas crianças de domicílios atendidos pelo PETI contra crianças de outros municípios contra grupo de controle; e iii) impacto nas crianças de municípios que têm PETI contra o grupo de controle.

Os coeficientes das equações decorrentes destas especificações estimam os impactos do PETI nas crianças beneficiadas e o efeito transbordamento ("spillover effects”) do programa nos domicílios ou crianças que não participam dele.

Como só havia dados disponíveis para 1999, os autores pressupõem que as localidades que não implementaram o PETI formavam grupos de controle adequados, e notam que outros estudos comparam esta técnica com o método de diferenças em diferenças, por exemplo, chegando a resultados similares.

Yap, Sedlacek \& Orazem (2001) concluem então que o programa é eficiente em limitar o trabalho infantil. Porém, embora os pais concordem em retirar os filhos do trabalho, é difícil fazer com que isso realmente ocorra dado que o trabalho no domicílio ou para o consumo da família figura entre as principais atividades das crianças. Assim, o PETI tem menos eficiência em reduzir a probabilidade de uma criança trabalhar em jornadas inferiores a dez horas semanais.

Concluem também que há evidência de especialização de crianças em estudo ou trabalho nas estimativas feitas para a Bahia e Sergipe, o que os leva a afirmar que embora os impactos sobre as crianças participantes sejam positivos, os efeitos sobre os não participantes do PETI são ambíguos.

Saboia \& Rocha (2002) sugerem uma metodologia de avaliação de programas de renda mínima, aplicando-a aos dados dos registros do programa do Distrito Federal e da PNAD de 1995.

Foi proposto um modelo de avaliação em três módulos distintos: i) análise do processo de seleção dos beneficiários; ii) análise de focalização; e iii) análise e mensuração dos efeitos do programa na população beneficiária.

O objetivo do primeiro módulo é saber se os critérios básicos adotados pelo 
programa têm sucesso em atingir e mobilizar a população pobre. Nesta fase, as informações prestadas pelos candidatos foram avaliadas, e, em seguida, as características dos beneficiários foram comparadas com as dos não-beneficiários, de forma que a eficácia do processo de seleção pudesse ser avaliada. Segundo Saboia \& Rocha (2002), o sistema de pontuação utilizado no Distrito Federal, baseada não somente na renda observada, colaborou para melhorar o foco no processo de seleção dos beneficiários, mas os questionários ainda poderiam ser melhorados e remodelados.

A análise de focalização foi realizada comparando as características das famílias selecionadas com a população, aplicando as regras do programa aos dados da PNAD ${ }^{23}$ de 1995 . Os autores notaram que a população foi corretamente focalizada, pois os dois grupos apresentavam rendas semelhantes, enquanto os indicadores socioeconômicos mostravam que as famílias selecionadas pelo programa viviam em piores condições que a média da população.

O terceiro módulo verifica o grau de sucesso em atingir os objetivos do programa, e é baseado essencialmente nos dados dos candidatos. A avaliação de curto prazo é limitada a verificar mudanças no consumo resultantes do aumento de renda, ou mudanças comportamentais derivadas dos aspectos do programa, como o aumento do engajamento e da freqüência escolar. Melhorias de aspectos nutricionais, do desempenho escolar e envolvimento com a comunidade são observáveis no médio prazo, enquanto avanços em capital humano e auto-suficiência de renda, que podem realmente quebrar o ciclo da pobreza, apenas são notados em análises no longo prazo.

Saboia \& Rocha (2002) sugerem ainda um quarto módulo diferente dos demais porque sua metodologia limita-se à avaliação da implementação do programa em si, envolvendo a análise de custos e fontes de financiamento, e de respostas ao aumento da demanda por serviços públicos decorrentes do programa.

23 Como a PNAD é amostral, em alguns casos seus dados podem não ser comparáveis com os beneficiários do programa, e a alternativa disponível é utilizar os dados do Censo, que por sua vez pode apresentar uma defasagem temporal grande. Então podem ser utilizados dados de pesquisas domiciliares ou cadastrais do próprio município. 
De forma geral, os autores concluem que o programa de renda mínima do Distrito Federal atingia seus objetivos, mas o sistema de pontuação deveria ser revisto, principalmente para eliminar tendenciosidades na seleção. Além disso, algumas questões não haviam ficado muito claras, como o critério de exclusão do programa, que permitia que uma família entrasse e saísse dele alternadamente, aumentando os custos de monitoramento e reduzindo a motivação dessas famílias em participar.

Bourguignon, Ferreira \& Leite (2002), propõem a utilização de um método de microssimulação para avaliar, ex-ante, os impactos do Bolsa Escola federal na escolha ocupacional das crianças e na pobreza e desigualdade correntes.

Os autores estimaram um modelo lógite multinomial para as decisões ocupacionais (estudar e trabalhar, só estudar, só trabalhar, não estudar nem trabalhar), utilizando os dados da PNAD de 1999. Com os parâmetros obtidos, fizeram simulações que possibilitaram prever a escolha ocupacional das crianças sob diferentes hipóteses, relacionadas basicamente ao valor das transferências e o nível de renda domiciliar crítico para a seleção do candidato.

Os resultados obtidos mostram que a resposta para a educação é considerável, já que mais de um terço das crianças entre dez e 15 anos que não freqüentavam a escola passariam a fazê-lo com a implementação do programa, e entre os mais pobres esta proporção é ainda maior, pois metade das crianças escolheria estudar. Porém, a proporção de crianças que escolheria trabalhar e estudar não cairia ${ }^{24}$.

Os impactos na redução da pobreza não seriam tão expressivos quanto no aumento da escolaridade, pois o programa reduziria a incidência da pobreza em apenas um ponto percentual e o coeficiente de Gini em apenas meio ponto.

Bourguignon, Ferreira \& Leite (2002) concluem que o nível de focalização do Bolsa Escola é adequado, mas que reduzir a pobreza por este instrumento não é um processo rápido, embora seja efetivo.

\footnotetext{
${ }^{24}$ Os autores argumentam que essa proporção deve até ter um aumento marginal.
} 
Cardoso \& Souza (2003) utilizaram os microdados do Censo 2000 para avaliar, ex-post, o impacto das transferências de renda vinculadas à educação na incidência de trabalho infantil e no engajamento escolar. O Censo Demográfico coleta informações dos indivíduos a partir dos dez anos de idade, portanto os autores puderam avaliar o impacto do Bolsa Escola somente sobre a população de dez a quinze anos. Além disso, a informação disponível é o valor recebido do governo em programas de renda mínima, Bolsa Escola ou seguro desemprego, e foi necessária alguma manipulação das informações para definir a variável de interesse, contudo sem perder o rigor da análise.

Como no máximo três crianças por família são atendidas pelo programa, haverá um grupo de indivíduos que preenchem os requisitos necessários, mas que não são beneficiados. Assim, é possível construir um grupo de controle adequado a partir de técnicas de matching ${ }^{25}$, e estimar a probabilidade de a criança trabalhar, dadas determinadas características, inclusive a de participar do programa de Bolsa Escola (variável binária que assume o valor um se a criança recebe ou zero se não recebe). Utilizando o critério de "vizinhança próxima", para cada observação do grupo de tratamento foi determinada uma observação no grupo de controle, baseando-se na estimativa de propensity score obtida por meio de modelo lógite em que a variável dependente é pertencer ou não a uma família que recebe a transferência de renda.

Em todos os modelos sugeridos por Cardoso \& Souza (2003), as transferências tiveram impacto positivo e significativo sobre o engajamento escolar, mas não sobre o trabalho infantil. Os autores concluem então que os programas de renda mínima e Bolsa Escola têm algum impacto na escolaridade, mas não inibem o trabalho das crianças.

${ }^{25}$ Propensity matching score method 


\section{MATERIAL E MÉTODOS}

"É necessário medir o que é mensurável, e tornar mensurável aquilo que não o é".

Galileu

Neste capítulo descreve-se o modelo econômico de determinação do trabalho infantil adotado como referencial teórico, bem como as estratégias utilizadas para medir o impacto dos programas de bolsa escola no trabalho das crianças.

As estratégias adotadas foram: i) estimar um modelo próbite em que a variável dependente assume o valor um se a criança trabalha e zero se não trabalha, e entre as variáveis explanatórias tradicionalmente encontradas na literatura incluir uma variável binária indicativa da participação ou não de programas de renda mínima vinculada à educação; e ii) estimar uma equação de número de horas trabalhadas por mínimos quadrados, ponderados pelo fator de expansão da amostra, em que a variável dependente é o número de horas semanais normalmente trabalhadas e as variáveis explicativas são as mesmas do modelo próbite.

Também são apresentadas as variáveis selecionadas e a base de dados que será utilizada.

\subsection{Um modelo econômico de determinação do trabalho infantil}

Kassouf (2002) descreve o modelo de determinação do trabalho infantil elaborado por Rosenzweig (1981), considerando que a família é composta de mãe, pai e 
uma criança ${ }^{26}$. Esta simplificação foi utilizada para facilitar a notação, e será seguida no presente trabalho.

Rosenzweig (1981) assume que a família maximiza uma função utilidade $(U)$ com as características esperadas (contínua, estritamente crescente, quase-côncava e diferenciável), e que a utilidade é função de bens comprados e consumidos $(X)$, do tempo de lazer da mãe $\left(l_{m o}\right)$ e do pai $\left(l_{f a}\right)$, do tempo de lazer da criança $\left(l_{c h}\right)$, e do nível de escolaridade da criança $\left(S_{c h}\right)$.

Assim, a função utilidade que será maximizada pode ser escrita como:

$$
U=U\left(X, l_{m o}, l_{f a}, l_{c h}, S_{c h}\right)
$$

Assume-se também que o nível de escolaridade da criança requer tempo $\left(t_{s c h}\right)$ e alguns bens específicos à educação $\left(X_{s}\right)$, tais como material escolar, taxas escolares, transporte, etc., de forma que a escolaridade da criança pode ser escrita por meio da seguinte função:

$$
S_{c h}=s\left(t_{s c h}, X_{s}\right)
$$

A restrição de renda total $(F)$ com a qual a família se defronta é dada por:

$$
\begin{aligned}
& F=V+T_{m o} W_{m o}+T_{f a} W_{f a}+T_{c h} W_{c h}= \\
& P_{x} X+W_{m o} l_{m o}+W_{f a} l_{f a}+P_{s} X_{s}+W_{c h}\left(l_{c h}+t_{s c h}\right)
\end{aligned}
$$

onde $V$ é a renda não-salarial, $T_{m o}, T_{f a}$ e $T_{c h}$ são o tempo total disponível da mãe, pai e criança, $W_{m o}, W_{f a}$ e $W_{c h}$ são os salários da mãe, pai e criança, e $P_{x}$ e $P_{s}$ são os preços de $X$ e $X_{s}$.

A restrição de renda total permite observar que o rendimento total da criança é $W_{c h}\left(T_{c h}-l_{c h}-t_{s c h}\right)$. Observa-se também que os custos diretos da escolaridade são $P_{s} X_{s}$ e o custo do tempo de escolaridade é $W_{c h} t_{s c h}$.

\footnotetext{
${ }^{26}$ Kassouf (2002) nota que "Alguns autores não incluem o número de irmãos na família por considerarem estas variáveis endógenas, tratando com um problema de decisão de fertilidade [Da Vanzo (1972), Rosenzweig (1981)]". Seguindo a notação adotada neste trabalho, o número de crianças é considerado exógeno, conforme proposto, por exemplo, por Jensen \& Nielsen (1997) e Grootaert \& Patrinos (1998).
} 
Quando a função utilidade é maximizada sujeita à restrição de renda total, surge um conjunto de equações de demanda para as variáveis endógenas $l_{m o}, l_{f a}, l_{c h}, t_{s c h}, X$, $X_{s}$ em função das variáveis exógenas $W_{m o}, W_{f a}, W_{c h}, P_{x}, P_{s}, V$, ou seja, as funções de demanda têm a forma:

$$
D=f_{D}\left(W_{m o}, W_{f a}, W_{c h}, P_{x}, P_{s}, V\right)
$$

onde $D$ representa $l_{m o}, l_{f a}, l_{c h}, t_{s c h}, X, X_{s}$.

Tomando-se as formas reduzidas das equações de demanda, é possível analisar o efeito de uma variável exógena sobre as endógenas.

Uma mudança no salário da criança $W_{c h}$ e no salário da mãe $W_{m o}$ sobre o tempo de trabalho da criança $t_{w c h}=T_{c h}-l_{c h}-t_{s c h}$ e do tempo de trabalho da mãe $t_{w m o}=T_{m o}-l_{m o}$ podem ser decompostos nos efeitos preço (utilidade constante) e renda, da seguinte forma:

$$
\begin{aligned}
& \frac{\partial t_{w m o}}{\partial W_{m o}}=-\left.\frac{\partial l_{m o}}{\partial W_{m o}}\right|_{u=\bar{u}}-t_{w m o} \frac{\partial l_{m o}}{\partial F} \\
& \frac{\partial t_{w m o}}{\partial W_{c h}}=-\left.\frac{\partial l_{m o}}{\partial W_{c h}}\right|_{u=\bar{u}}-t_{w c h} \frac{\partial l_{m o}}{\partial F} \\
& \frac{\partial t_{w c h}}{\partial W_{m o}}=-\left.\frac{\partial\left(l_{c h}+t_{s c h}\right)}{\partial W_{m o}}\right|_{u=\bar{u}}+t_{w m o} \frac{\partial t_{w c h}}{\partial F} \\
& \frac{\partial t_{w c h}}{\partial W_{c h}}=-\left.\frac{\partial\left(l_{c h}+t_{s c h}\right)}{\partial W_{c h}}\right|_{u=\bar{u}}+t_{w c h} \frac{\partial t_{w c h}}{\partial F}
\end{aligned}
$$


Por meio das equações acima, pode-se prever o sinal positivo para o primeiro termo do lado direito das equações eq. (9) e eq. (12). Sabe-se ainda que os primeiros termos das equações eq. (10) e eq. (11) devem ser iguais por causa da condição de simetria. Também por causa da condição de simetria, qualquer mudança no salário da criança terá um efeito sobre o tempo de trabalho da mãe, que será igual ao efeito de uma mudança no salário da mãe sobre o tempo de trabalho da criança se o nível de utilidade for mantido constante.

Segundo Rosenzweig (1981), o efeito salário cruzado observado no comportamento da oferta de trabalho na família ou domicílio faz com que as condições de trabalho de mulheres adultas tenham impactos significativos no emprego das crianças, mesmo que os empregadores não as considerem como mão-de-obra substituta.

Mesmo pressupondo que um aumento na renda aumente o consumo de bens, os sinais das equações eq. (9) a eq. (12) não podem ser previstos, já que os efeitos preço (utilidade constante) e renda têm sinais opostos. Entretanto, pode-se testar o modelo por meio da estimação do efeito renda, através da renda não-salarial ( $V)$, e do efeito preço total ou não compensado.

Outro ponto a ser destacado é que políticas podem ser recomendadas analisando as relações existentes entre as variáveis das equações de demanda na forma-reduzida.

Por exemplo, o efeito de uma mudança no tempo de trabalho da criança na oferta de trabalho do pai $\left(t_{w f a}\right)$, é obtido por:

$$
\frac{\partial t_{w f a}}{\partial t_{w c h}}=\frac{\left(\partial t_{w f a} / \partial W_{c h}\right)_{u=\bar{u}}}{\left(\partial t_{w c h} / \partial W_{c h}\right)_{u=\bar{u}}}
$$

Isto significa que o efeito de uma restrição imposta à oferta de trabalho da criança sobre o nível de oferta de trabalho dos pais e o efeito do salário da criança sobre a oferta de trabalho do pai terão o mesmo sinal, uma vez que $\partial t_{w c h} / \partial W_{c h}$ é positivo. 
Se a quantidade de tempo dedicada pela criança ao trabalho for pequena, então a equação eq. (14) abaixo será uma boa aproximação do efeito salário (preço) com utilidade constante.

$$
\frac{\partial t_{w f a}}{\partial W_{c h}}=-\left.\frac{\partial l_{f a}}{\partial W_{c h}}\right|_{u=\bar{u}}-t_{w c h} \frac{\partial l_{f a}}{\partial F}
$$

De acordo com as pressuposições e derivações feitas, o tempo da criança pode ser alocado para lazer, escola, atividades domiciliares ou trabalho, e esta alocação é feita pela família com base: i) na capacidade de produção da criança e dos pais no domicílio e no mercado de trabalho; e ii) no grau de substituição da força de trabalho entre as crianças e seus pais. Kassouf (2002) nota que "enquanto as atividades domiciliares realizadas pelas crianças podem permitir que mães ou irmãos mais velhos entrem no mercado de trabalho, as atividades de mercado realizadas pelas crianças permitem a elas contribuírem para o aumento da renda familiar".

\subsection{O modelo econométrico utilizado}

Dentre os métodos não experimentais, o mais adequado para o objetivo proposto é a aplicação de um modelo próbite, em que a variável dependente é a decisão de trabalhar, que assume o valor um quando a criança trabalha e zero quando não trabalha.

Modelos probabilísticos de escolha discreta são caracterizados por variáveis dependentes $y_{i}$ binárias, que assumem o valor $1 \mathrm{com}$ probabilidade $P_{i}$ e o valor zero com probabilidade $\left(1-P_{i}\right)$ A função densidade probabilidade de $y_{i}$ pode ser escrita como:

$$
g\left(y_{i}\right)=P_{i}^{y_{i}}\left(1-P_{i}\right)^{1-y_{i}}, \quad y_{i}=1,0
$$


Apesar de ser mais simples e de as estimativas dos parâmetros representarem os efeitos marginais, um modelo de probabilidade linear tem desvantagens, pois não é possível restringir as estimativas das probabilidades no intervalo [0,1], além de os erros serem naturalmente heterocedásticos ${ }^{27}$.

O modelo próbite é um modelo estatístico não linear nos parâmetros que relaciona a probabilidade de escolha $P_{i}$ a variáveis explicativas, de forma que a probabilidade permaneça no intervalo $[0,1]$. Seguindo a notação utilizada por Griffiths, Hill \& Judge (1993) para a derivação do modelo próbite de variável discreta, define-se um "índice de utilidade" $I_{i}$ para o $i$-ésimo indivíduo como:

$$
I_{i}=\mathbf{x}^{\prime} \hat{\mathbf{a}}
$$

onde

$$
\begin{aligned}
& \mathbf{x}_{i}^{\prime}=\left(\begin{array}{ll}
1 & x_{i 2} \ldots . x_{i K}
\end{array}\right), \mathrm{e} \\
& \hat{\mathbf{a}}=\left(\beta_{1}, \beta_{2}, \ldots, \beta_{k}\right)^{\prime}
\end{aligned}
$$

Conforme o valor das variáveis explicativas muda, o valor de $I_{i}$ também se altera, e quanto maior $I_{i}$, maior a utilidade que um indivíduo tem de escolher $y_{i}=1$, e consequentemente maior o valor de $P_{i}$, que é a probabilidade de um indivíduo $i$ escolher a opção em que $y_{i}=1$. Para descrever este tipo de comportamento da relação entre $I_{i}$ e $P_{i}$, o modelo próbite utiliza a função distribuição cumulativa da normal padronizada $N(0,1)$ avaliada em $I_{i}, F\left(I_{i}\right)$ :

$$
P_{i}=F\left(I_{i}\right)=F\left(\beta_{1}+\beta_{2} x_{i 2}+\ldots+\beta_{K} x_{i K}\right)=F\left(\mathbf{x}^{\prime} \hat{\mathbf{a}}\right)
$$

\footnotetext{
${ }^{27}$ Para maiores detalhes ver Judge et.al. (1988), Griffiths et.al. (1993) ou Greene (2000).
} 
A função distribuição cumulativa é dada por:

$$
P_{i}=F\left(I_{i}\right)=P\left[z \leq I_{i}\right]=\int_{-\infty}^{I_{i}}(2 \pi)^{-1 / 2} e^{-z^{2} / 2} d z
$$

onde $z$ é uma variável aleatória normal padronizada. Assim, a probabilidade $P_{i}$ de $y_{i}=1$ varia entre zero e um conforme o desejado, uma vez que é a probabilidade de a variável aleatória $z$ ser menor ou igual a $\mathbf{I}_{\mathrm{i}}=\mathbf{x}^{\prime} \boldsymbol{\beta}$.

Segundo Greene (2000), o modelo de probabilidade em que Prob $(\mathrm{Y}=1)=\mathrm{F}(\mathbf{x}$, $\boldsymbol{\beta})$ e Prob $(Y=0)=1-F(\mathbf{x}, \boldsymbol{\beta})$ pode ser escrito como uma regressão do tipo:

$$
E[y \mid \mathbf{x}]=0\left[1-F\left(\hat{\mathbf{a}}^{\prime} \mathbf{x}\right)\right]+1\left[F\left(\hat{\mathbf{a}}^{\prime} \mathbf{x}\right)\right]=F\left(\hat{\mathbf{a}}^{\prime} \mathbf{x}\right)
$$

Para qualquer distribuição utilizada, os parâmetros do modelo não corresponderão ao efeito marginal, que é dado por:

$$
\frac{\partial E[y \mid \mathbf{x}]}{\partial \mathbf{x}}=\left\{\frac{d F\left(\hat{\mathbf{a}}^{\prime} \mathbf{x}\right)}{d\left(\hat{\mathbf{a}}^{\prime} \mathbf{x}\right)}\right\} \hat{\mathbf{a}}=f\left(\hat{\mathbf{a}}^{\prime} \mathbf{x}\right) \hat{\mathbf{a}}
$$

onde $f($.$) é uma função densidade probabilidade que corresponde a distribuição$ cumulativa, $F($.). Como o modelo próbite utiliza a distribuição normal padronizada, o resultado será:

$$
\frac{\partial E[y \mid \mathbf{x}]}{\partial \mathbf{x}}=\phi\left(\hat{\mathbf{a}}^{\prime} \mathbf{x}\right) \hat{\mathbf{a}}
$$


onde $\phi(z)$ representa a função densidade normal padronizada, ou seja, $\phi(z)=$ $(2 \pi)^{-1 / 2} e^{-z^{2} / 2}$.

Além de medir o impacto dos programas de Bolsa Escola na decisão da família de inserir ou não a criança no mercado de trabalho, será adotada a estratégia de verificar o impacto de participar desses programas sobre o número de horas semanais de trabalho infantil ofertado pelas famílias que inserem suas crianças no mercado de trabalho, utilizando o método de mínimos quadrados ponderados, o que também será útil como confirmação dos resultados obtidos nas regressões próbite.

\subsection{As variáveis selecionadas}

O objetivo desta pesquisa, como dito anteriormente, é avaliar o impacto de programas de renda mínima vinculado à educação - Bolsa Escola - sobre a probabilidade de trabalhar e sobre o número de horas trabalhadas, para as crianças que formam a população alvo do programa, ou seja, sobre os indivíduos que têm entre seis e quinze anos de famílias com renda mensal igual ou inferior a noventa reais por pessoa.

A variável dependente no modelo próbite de oferta de trabalho é se a criança trabalha ou não, dada por uma variável binária que assume o valor um se a criança trabalha e zero se não trabalha. No modelo de regressão linear estimado por mínimos quadrados, ponderados pelo fator de expansão da amostra, para as crianças que trabalham, a variável dependente é o número de horas semanais trabalhadas.

As variáveis explicativas são as mesmas tanto para a equação de oferta de trabalho quanto para a de horas trabalhadas ${ }^{28}$.

A principal variável explicativa para os objetivos deste trabalho é se a criança está inscrita ou não em programas de transferência de renda vinculada ao engajamento

\footnotetext{
${ }^{28}$ As variáveis explicativas que compõem as equações reduzidas dos modelos foram escolhidas com base em Kassouf (2002), que por sua vez é baseado no modelo econômico formalizado por Rosenzweig (1981).
} 
escolar - variável binária que tem valor um se a criança participa do Bolsa Escola e zero se não participa. Como participar do Bolsa Escola implica em reduzir o tempo disponível para o trabalho espera-se que a estimativa deste coeficiente seja negativo, o que significa que participar de programas desta natureza reduzam a probabilidade de trabalho das crianças, assim como o número de horas trabalhadas.

Também foram incluídas no modelo variáveis binárias para captar o efeito de características individuais das crianças, tais como sexo e raça. A variável sexo assume o valor um para meninos e zero para meninas. Para captar o efeito de diferenças raciais foram especificadas as variáveis branca, preta, amarela e parda (que têm valor um quando a pessoa declara ser de cor branca, preta, amarela e parda, respectivamente, e zero caso contrário); a variável preta foi omitida.

Ainda para captar efeitos de características individuais, a idade da criança foi incluída. Quanto mais velha é a criança mais oportunidades ela terá no mercado de trabalho, portanto espera-se que o coeficiente estimado da idade tenha o sinal positivo.

De acordo com a literatura consultada, variáveis de background familiar são importantes determinantes do trabalho infantil. Sendo assim, foram incluídas no modelo características da mãe e do pai da criança, tais como idade, educação e logaritmo dos salários estimados.Para identificar o pai da criança foi utilizado o mesmo procedimento descrito por Kassouf (2002): foi considerado "pai" o indivíduo com mais de 20 anos e que se declarou chefe ou esposo. Apesar de haver a possibilidade de considerar como pai um avô ou irmão mais velho, acredita-se que na maioria das famílias o pai verdadeiro será identificado e que essa possibilidade não afeta os resultados, pois é identificado um membro adulto da família do sexo masculino e responsável pela criança, que de qualquer forma pode afetar a decisão de alocação do tempo da criança.

As estimativas do logaritmo dos salários, tanto do pai quanto da mãe, foram obtidos por meio do procedimento de Heckman, utilizando como variável dependente o logaritmo dos salários observados e como variáveis explicativas a idade, a experiência e a educação dos pais. Tais estimativas encontram-se no Apêndice. São esperados sinais negativos para as estimativas dos coeficientes, pois quanto maior a renda dos adultos da 
família menor a probabilidade de a criança trabalhar. Como os salários são estimados em função da educação, não foi incluído nas regressões o número de anos de estudo dos pais.

As variáveis que captam efeitos das regiões foram incluídas de modo que características exógenas às famílias sejam captadas, tornando o efeito das variáveis de interesse mais "limpos". Ao criar uma variável binária para cada unidade da federação ${ }^{29}$, que assume o valor um se a criança mora em determinado Estado e zero caso contrário, espera-se que as diferenças regionais que poderiam impactar no trabalho infantil sejam captadas.

Assim, características como nível de salários, infra-estrutura e qualidade das escolas e da educação, diferenças culturais e até mesmo do próprio mercado de trabalho, como o nível de salários e as oportunidades de emprego, estarão representadas nas diferenças entre as unidades da federação, permitindo que o foco do trabalho seja dado à variável de interesse, que é a participação em programas de Bolsa Escola.

\subsection{As bases de dados}

O Brasil possui um sistema de pesquisas familiares bem estruturado, composto por mais de três décadas de amostras, que complementam as informações obtidas nos censos demográficos.

A Pesquisa Nacional por Amostra de Domicílios (PNAD) e o Censo Demográfico, que têm informações coletadas e disponibilizadas pelo Instituto Brasileiro de Geografia e Estatística (IBGE), são as bases de dados disponíveis mais indicadas para uma pesquisa de caráter empírico como a que se propõe neste trabalho.

Neste trabalho, serão utilizados os microdados da PNAD 2001, que traz encarte especial sobre o trabalho infantil, elaborado em conjunto com a OIT. Apesar de o Censo Demográfico perguntar o valor dos rendimentos provenientes de Bolsa Escola, renda

\footnotetext{
${ }^{29}$ A variável que representa o Estado de Pernambuco foi omitida.
} 
mínima ou seguro desemprego, permitindo que a análise seja feita utilizando seus microdados, a PNAD é preferida, principalmente, porque em 2001 é mais aprofundada em relação ao Censo ao pesquisar as características da população que tem entre cinco e dezessete anos de idade, com questões mais aprofundadas sobre educação e trabalho, enquanto o Censo tem informações apenas para os indivíduos com mais de dez anos de idade.

O sistema de pesquisas familiares PNAD foi implantado no Brasil a partir de 1967, com a finalidade de produzir informações básicas para o estudo do desenvolvimento sócio-econômico do País. Abrange a população residente nas unidades familiares, dividindo-se em duas partes: i) pesquisa de caráter permanente, que são as características gerais da população, tais como educação, trabalho, rendimento e habitação e, ii) pesquisa de caráter variável, tais como migração, fecundidade, nupcialidade, saúde, nutrição entre outros.

A pesquisa é realizada anualmente, excetuando os anos de censo, no ultimo trimestre do ano $^{30}$. Quanto à abrangência, é dividida em cinco grandes regiões sendo elas: sul, sudeste, centro-oeste, nordeste e norte, e esta última refere-se somente a parcela urbana (exceção para o Tocantins). Em 2001 participaram da amostra 378.837 pessoas.

A PNAD é realizada através de amostras probabilísticas de domicílios obtidas em três estágios de seleção: unidades primárias (municípios); unidades secundárias (setores censitários); e unidades terciárias (unidades domiciliares). O processo de expansão da amostra utiliza estimadores de razão cuja variável independente é a projeção da população residente, segundo tipo de área (região metropolitana e não metropolitana). Estas projeções consideram a evolução populacional ocorrida entre os censos, sob a hipótese de crescimento associado a taxas de fecundidade, mortalidade e migração.

Além disso, em 2001 foram pesquisadas características de saúde e trabalho da

\footnotetext{
${ }^{30}$ Para a PNAD de 2001 o mês de referência é setembro.
} 
população de 5 a 17 anos, num encarte especial com questionário elaborado em parceria com a OIT. O encarte traz questões como por que a criança trabalha, por que não freqüenta a escola, e se é beneficiária de programas sociais de incentivo à educação (como Bolsa Escola, PETI e Renda Mínima). 


\section{RESULTADOS E DISCUSSÃO}

"O que temos são apenas ferramentas para o que pensamos". Sócrates

\subsection{Caracterização da amostra}

Nesta seção serão apresentados alguns dados da PNAD 2001, ponderados pelo fator de expansão da amostra, com o intuito de descrever as crianças brasileiras segundo a atividade que realizam - se trabalham, estudam, cuidam de afazeres domésticos - e qual o tempo gasto em tais atividades, estratificando por faixa de renda familiar e grupos de idade em alguns casos.

Como a população alvo dos programas de Bolsa Escola está na idade escolar, ou seja, tem mais de seis e menos de dezesseis anos de idade, e abaixo da linha de pobreza, serão apresentados os dados da população de seis a quinze anos cuja renda per capita familiar mensal é igual ou inferior a meio salário mínimo ${ }^{31}$, dividida em dois grupos: crianças de seis a dez anos, e crianças com mais de onze anos de idade.

O critério adotado para a divisão dos grupos de idade é o fato de que a criança deve concluir o primeiro ciclo do ensino fundamental aos dez anos, caso não haja repetência ou ingresso tardio na escola.

Quando a amostra é estratificada por grupos de idade nota-se os efeitos descritos por Sabóia \& Bregman (1993), de características diferentes para crianças em idades diferentes. A Figura 5 mostra que enquanto 17\% das crianças de onze a quinze anos conciliam estudo e trabalho $4 \%$ das mais novas exercem as duas atividades

\footnotetext{
${ }^{31}$ O salário mínimo vigente em 2001 era de R \$ 180,00. Sendo assim, a linha de pobreza adotada (meio salário mínimo mensal por pessoa) era equivalente a $\mathrm{R} \$ 90,00$ per capita por mês.
} 
simultaneamente. O predomínio é das crianças que apenas estudam - cerca de $80 \%$ embora $6 \%$ da amostra não estude nem trabalhe, e aproximadamente $3 \%$ dos mais velhos só trabalhe.

Embora a proporção dos que não fazem nada seja elevada, considerando o grupo de idade a que pertence a amostra, é provável que estas crianças não estejam na escola ou porque ainda não são obrigados ou não encontram vagas no ensino infantil para os que têm seis anos, ou porque evadiram por não acompanhar o curso no caso dos mais velhos. No último caso, não pode ser descartada a hipótese de que estas crianças tenham ingressado precocemente na escola e terminado o ensino obrigatório antes dos quinze anos. Sendo assim, a análise das crianças que nem estudam nem trabalham deve ser realizada com cautela.

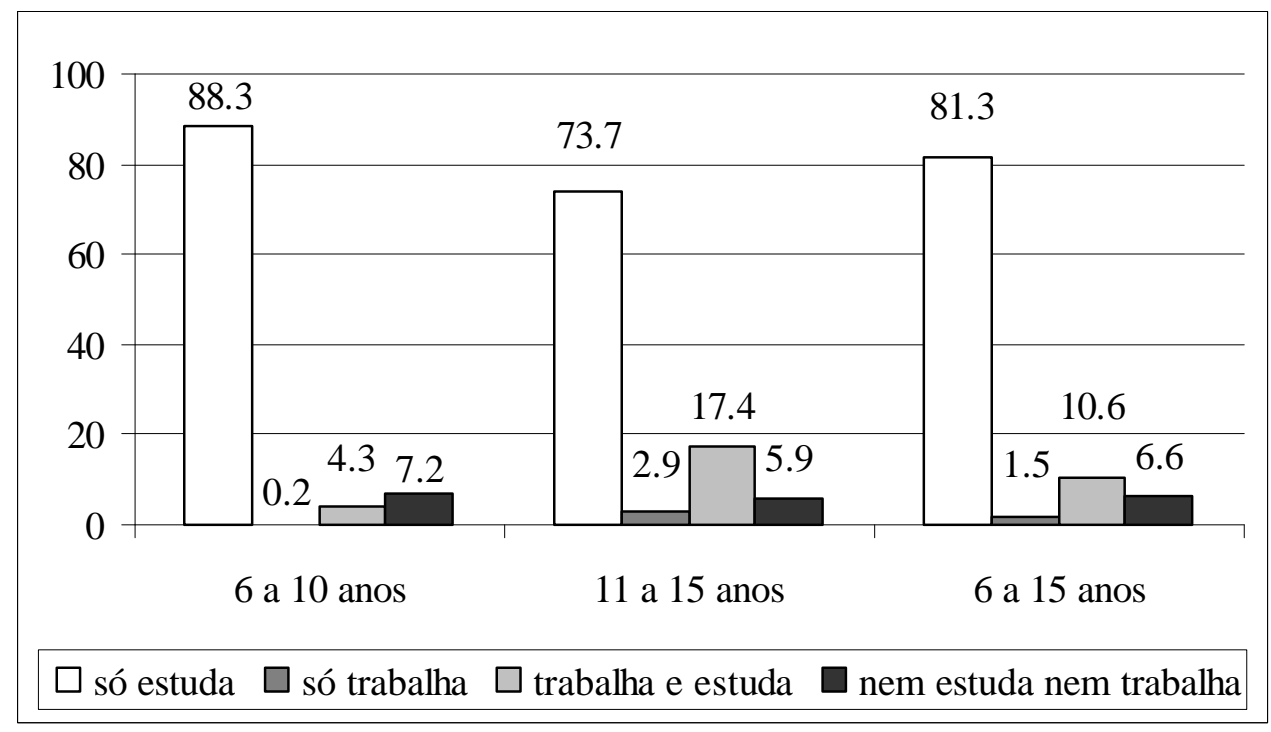

Figura 5 - Percentual de crianças de 6 a 15 anos que só estudam, estudam e trabalham, só trabalham ou não estudam nem trabalham, segundo grupos de idade; Brasil, 2001.

A Tabela 3 mostra a mesma informação, porém separa a amostra segundo a situação de domicílio. Observa-se, então, que as crianças da área rural, em todos os 
grupos de idade, trabalham mais que as da área urbana. Assim, a proporção dos que trabalham e estudam e dos que só trabalham é maior no campo, enquanto o percentual de crianças que só estudam é maior em áreas urbanas.

Tabela 3. Percentual de crianças de 6 a 15 anos que só estudam, só trabalham, estudam e trabalham ou não estudam nem trabalham, segundo grupos de idade e situação de domicílio; Brasil, 2001.

\begin{tabular}{lccccccc}
\hline & \multicolumn{2}{c}{6 a } & 10 & \multicolumn{2}{c}{11 a 15} & \multicolumn{2}{c}{6 a 15} \\
\cline { 2 - 7 } & rural & urbano & rural & urbano & rural & urbano \\
\hline só estuda & 80.39 & 91.26 & 55.40 & 83.94 & 68.40 & 87.92 \\
só trabalha & 0.56 & 0.08 & 4.83 & 1.75 & 2.61 & 0.84 \\
trabalha e estuda & 11.09 & 1.46 & 36.46 & 9.42 & 23.26 & 5.09 \\
nem estuda nem trabalha & 7.96 & 7.20 & 3.30 & 4.89 & 5.73 & 6.15 \\
\hline
\end{tabular}

Quanto à ocupação, 66\% do total das crianças trabalham em atividades agropecuárias ou extrativistas, e entre os mais novos a proporção de trabalhadores agrícolas é bem maior, $78 \%$ da amostra. Entre as demais ocupações a participação fica abaixo dos dez por cento, como ilustra a Figura 6. 


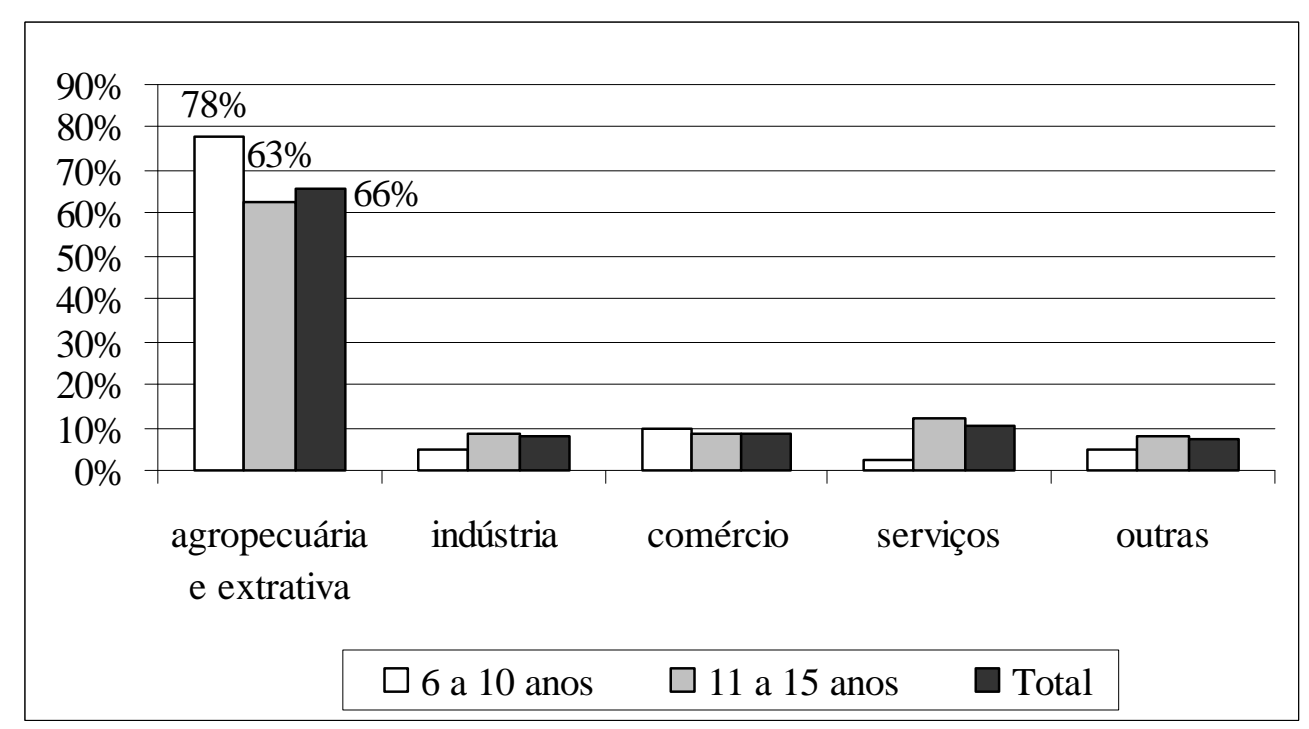

Figura 6 - Grupos de ocupação das crianças de 6 a 15 anos de idade segundo grupos de idade; Brasil, 2001.

Por meio da Figura 7 nota-se a relação entre trabalho infantil e renda per capita familiar líquida, ou seja, a renda familiar sem a renda da criança e dividida pelo número de componentes da família. Entre os que apenas estudam a média de renda é mais elevada ( $R$ \$ 46,2 mensais por pessoa entre os mais novos e $R \$ 49,3$ entre os mais velhos), e a média mais baixa está entre os que só trabalham ( $\mathrm{R} \$ 35,9$ mensais por pessoa para os que têm entre seis e dez anos de idade e $\mathrm{R} \$ 39$ para os maiores de onze anos).

A segunda maior média de renda mensal per capita está entre os que não estudam nem trabalham ( $\mathrm{R} \$ 44$ e $\mathrm{R} \$ 42$ para os mais velhos e mais novos, respectivamente), e em terceiro vem a renda per capita média dos que exercem as duas atividades simultaneamente (aproximadamente $\mathrm{R} \$ 40$ ). 


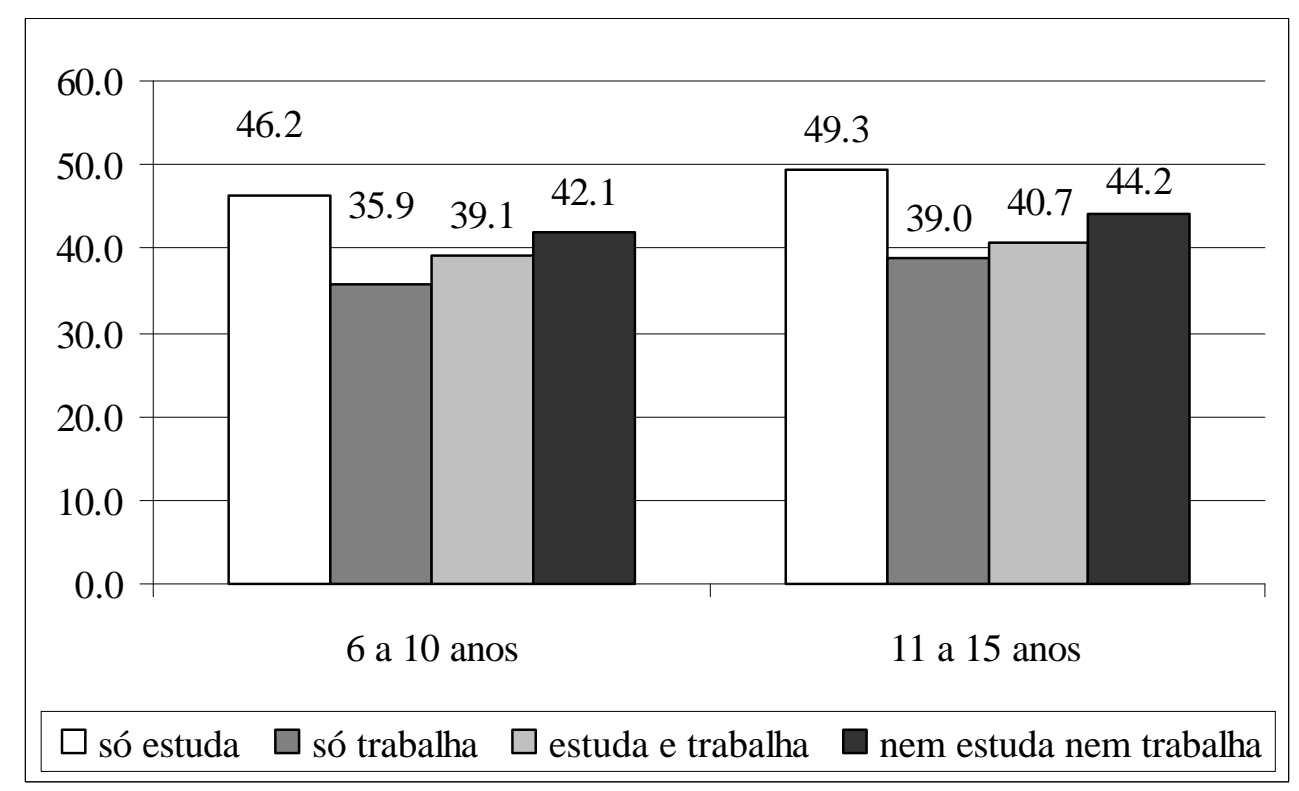

Figura 7 - Média da renda per capita familiar mensal, em reais, sem a renda da criança, de crianças de 6 a 15 anos que só estudam, estudam e trabalham, só trabalham ou não estudam nem trabalham, segundo grupos de idade; Brasil, 2001.

Além disso, conforme mostra a Tabela 4, nas áreas rurais a renda per capita média descontada a renda da criança é menor que nas áreas urbanas. Nota-se também que as maiores diferenças entre urbano e rural estão nos grupos que trabalha e estuda e que só estuda, principalmente entre os mais novos.

Tabela 4. Média da renda per capita familiar mensal, em reais, descontada a renda da criança, de crianças de famílias pobres entre 6 e 15 anos que só estudam, só trabalham, estudam e trabalham ou não estudam nem trabalham, segundo grupos de idade e situação de domicílio; Brasil, 2001.

\begin{tabular}{lcccc}
\hline & \multicolumn{2}{c}{6 a 10} & \multicolumn{2}{c}{11 a 15} \\
\cline { 2 - 5 } & rural & urbano & rural & urbano \\
\hline só estuda & 40.18 & 48.78 & 42.81 & 51.25 \\
só trabalha & 34.17 & 38.41 & 39.50 & 48.45 \\
trabalha e estuda & 36.34 & 49.60 & 38.37 & 50.91 \\
não estuda nem trabalha & 40.50 & 43.18 & 41.63 & 43.76 \\
\hline
\end{tabular}


Ainda admitindo que a pobreza é um importante determinante do trabalho precoce, a Figura 8 apresenta a participação da renda da criança na renda da família. Observa-se que o grupo que tem entre onze e quinze anos e só trabalha contribui com $15,7 \%$ da renda familiar, significativamente mais que os que têm a mesma idade e também estudam, que contribuem com 5,7\%, e que os que têm dez anos ou menos, cuja participação na renda da família está entre 1,2 e 2,5\% para quem estuda e não estuda, respectivamente.

A Figura 8 mostra ainda que a taxa salarial das crianças segue a mesma ordem. Os mais velhos recebem pouco mais de trinta centavos de real por hora trabalhada quando não estudam e dezenove centavos de real quando dividem o tempo do trabalho com a escola. A taxa salarial dos mais novos é mais parecida entre os que frequientam a escola e os que não freqüentam, e menos que a metade da dos mais velhos, variando de cinco a sete centavos de real por hora de trabalho. 


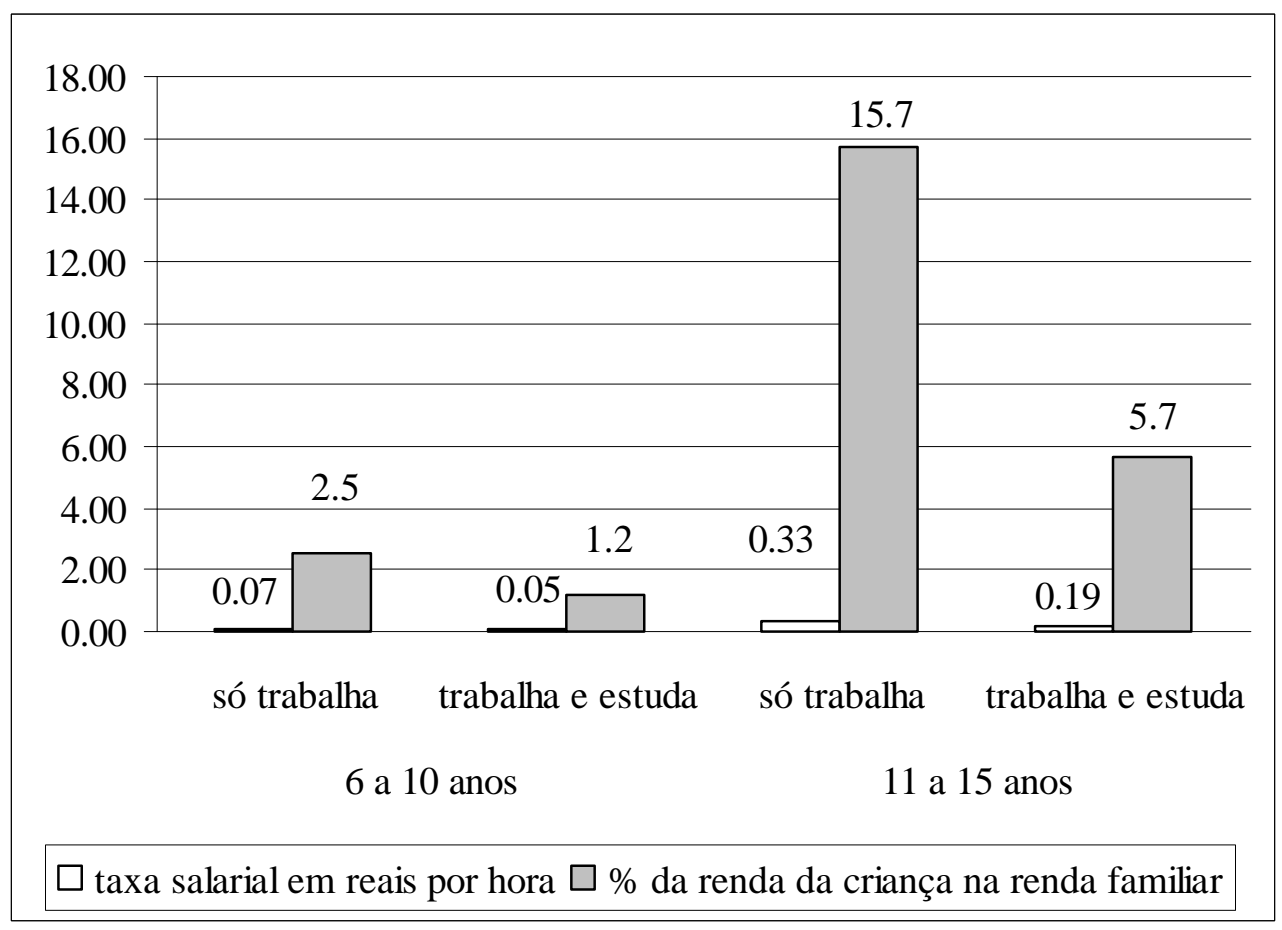

Figura 8 - Taxa salarial em reais por hora e participação da renda da criança na renda familiar, das crianças de 6 a 15 anos, segundo grupos de idade e engajamento escolar; Brasil, 2001.

Quando as crianças das áreas rural e urbana são consideradas separadamente, como na Tabela 5, nota-se que tanto as taxas salariais quanto a participação da renda da criança na renda familiar são significativamente maiores em áreas urbanas, independentemente do grupo de idade ou da atividade exercida.

Sendo assim, crianças de seis a dez anos de áreas rurais recebem cerca de um centavo de real por hora trabalhada; as que moram na cidade e estudam recebem R\$ 0,25/ hora e as que estudam R \$ 0,17 / hora, em média. A participação destas crianças na renda familiar segue a mesma tendência: as que trabalham e estudam são responsáveis por $0,19 \%$ da renda familiar quando são de áreas rurais e 4,34\% quando moram na cidade; os salários das que não estudam representam $0,28 \%$ da renda familiar na área rural e 8,35\% na área urbana. Análise semelhante pode ser feita considerando as crianças de seis a quinze anos, ainda com base na Tabela 5. As crianças que trabalham e estudam 
têm taxa salarial e participação na renda familiar menor do que as que só trabalham, e nas áreas rurais os valores encontrados são significativamente menores que nas áreas urbanas.

Tabela 5. Taxa salarial em reais por hora e participação da renda da criança na renda familiar, das crianças de 6 a 15 anos, segundo grupos de idade, engajamento escolar e situação de domicílio; Brasil, 2001.

\begin{tabular}{lcccc}
\hline & \multicolumn{2}{c}{ só trabalha } & \multicolumn{2}{c}{ trabalha e estuda } \\
\cline { 2 - 5 } & rural & urbano & rural & Urbano \\
\hline \multicolumn{1}{c}{ 6 a 10 anos } & & & & \\
Taxa salarial em reais por hora & 0.01 & 0.25 & 0.01 & 0.17 \\
$\begin{array}{l}\text { \% da renda da criança na renda familiar } \\
\text { 11 a 15 anos }\end{array}$ & 0.28 & 8.35 & 0.19 & 4.34 \\
$\begin{array}{l}\text { Taxa salarial em reais por hora } \\
\text { \% da renda da criança na renda familiar }\end{array}$ & 0.16 & 0.54 & 0.06 & 0.41 \\
\hline
\end{tabular}

As crianças trabalham em média 34 horas semanais quando não estudam e 21 quando estudam, conforme mostra a Figura 9. No entanto, aqueles que têm entre seis e dez anos apresentam jornada bem menor que a média, 16 e 18 horas semanais quando estudam e quando não estudam, respectivamente. 


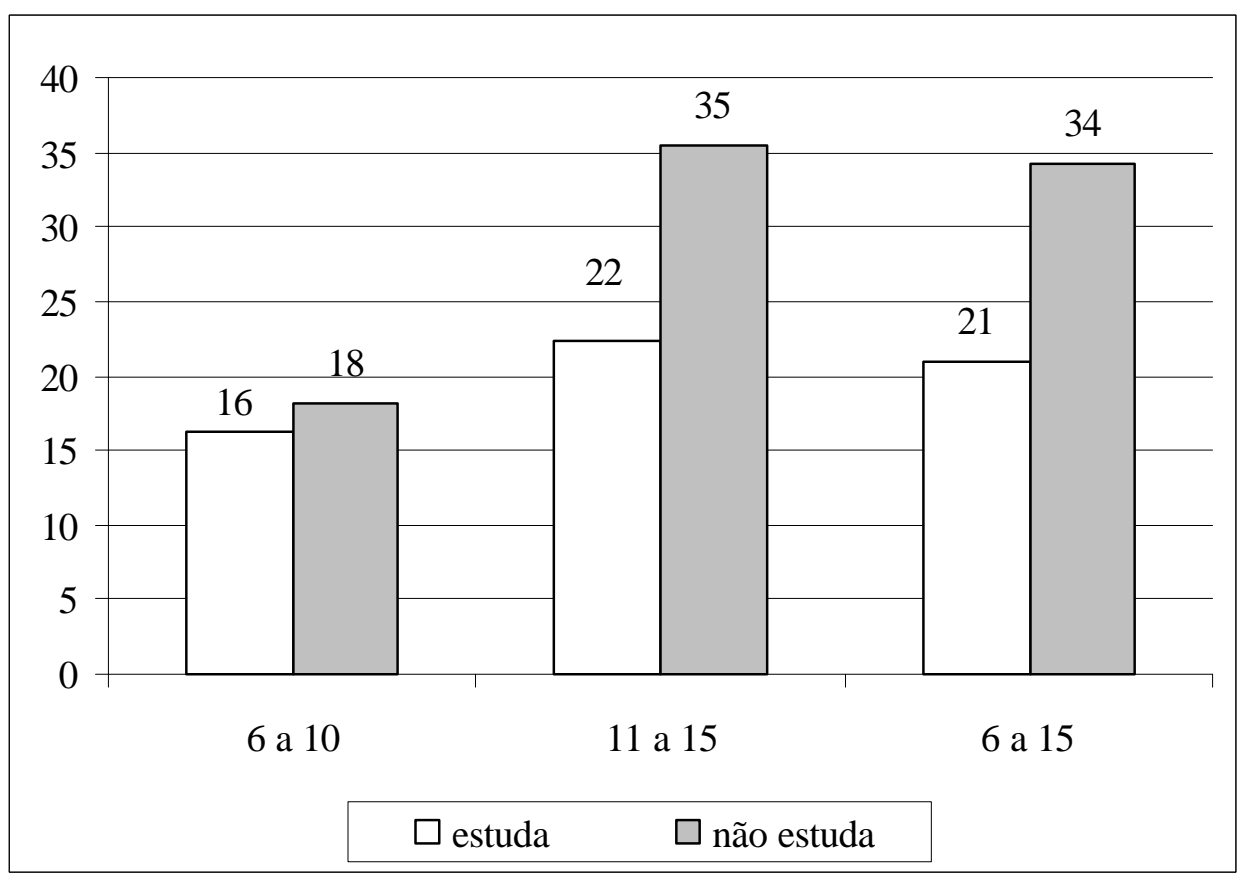

Figura 9 - Jornada semanal média de crianças de 6 a 15 anos que estudam e que não estudam, segundo grupos de idade; Brasil, 2001.

Ainda em relação à jornada de trabalho das crianças, observa-se por meio da Tabela 6 que as crianças das áreas rurais trabalham em média menos que as das áreas urbanas, com exceção das que têm entre seis e dez anos e não estudam, que trabalham em média duas horas semanais a mais no campo que na cidade.

Tabela 6. Jornada de trabalho semanal média de crianças de 6 a 15 anos que estudam e que não estudam, segundo grupos de idade e situação de domicílio; Brasil, 2001.

\begin{tabular}{lcccccc}
\hline & \multicolumn{2}{c}{6 a 10 anos } & \multicolumn{2}{c}{11 a 15} & \multicolumn{2}{c}{6 a 15} \\
\cline { 2 - 7 } & rural & urbano & rural & urbano & rural & urbano \\
\hline estuda & 16 & 16 & 21 & 24 & 20 & 23 \\
não estuda & 19 & 17 & 34 & 36 & 33 & 35 \\
\hline
\end{tabular}

As informações sobre taxa salarial e jornada médias das crianças remetem à discussão sobre os ganhos do trabalho percebidos pelas crianças e sua relação com o 
valor das bolsas concedidas pelo governo aos beneficiários dos programas de incentivo à demanda por educação.

Kassouf, Dorman \& Nunes (2003) estimaram em R \$ 88,00 a média de salários pagos para crianças brasileiras no meio urbano e em $\mathrm{R} \$ 77,00$ no meio rural. Entretanto, analisando os dados para a amostra estudada, composta apenas das crianças entre seis e quinze anos cuja renda familiar per capita é inferior a noventa reais (ou meio salário mínimo em valores de 2001), verifica-se que a média de rendimentos do trabalho é de $\mathrm{R}$ \$ 44 entre os que não estudam e R\$ 13 entre os que freqüentam a escola. Para os que têm entre onze e quinze anos a média salarial é de $\mathrm{R}$ \$ 47 e $\mathrm{R}$ \$ 16 mensais para os que só trabalham e para os que trabalham e estudam, respectivamente, enquanto entre os que têm dez anos ou menos a média de salários é de apenas três reais por mês. Estas informações podem ser visualizadas por meio da Figura 10.

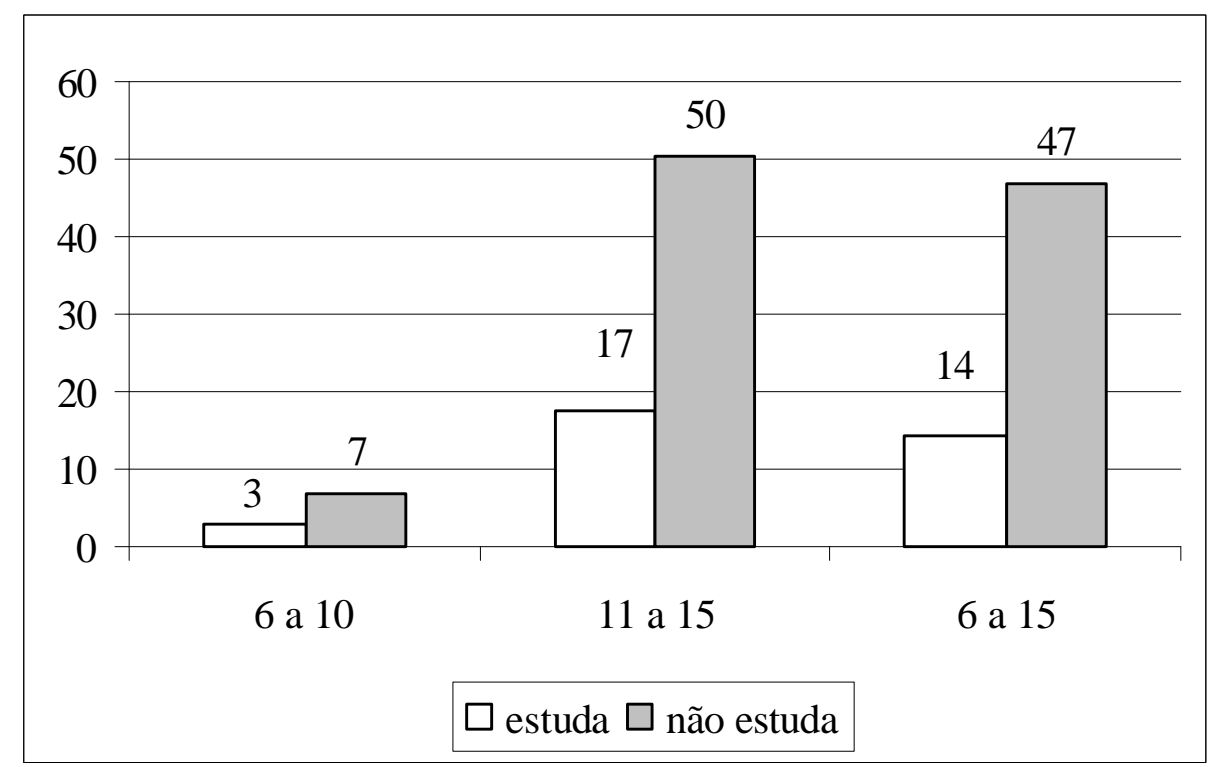

Figura 10 - Remuneração média mensal do trabalho principal das crianças de 6 a 15 anos que estudam e que não estudam, segundo grupos de idade; Brasil, 2001.

Sendo assim, é possível observar que o valor da bolsa concedida aos 
beneficiários dos programas Bolsa Escola, que é de $\mathrm{R} \$ 15$ por criança até o limite de três crianças por família, apenas compensa o custo de oportunidade, representado pelo salário de mercado, das crianças com dez anos ou menos e das que têm entre onze e quinze anos e já freqüentam a escola.

Para as famílias de crianças que estudam, participar do programa significará aumentar a renda total familiar sem alterar as decisões de alocação de tempo de seus membros. Entre as que não estudam haveria aumento na renda gerada pelas crianças menores, e redução naquela proveniente do trabalho das crianças com onze anos ou mais. Portanto, estas últimas tenderiam a não se inscrever no Bolsa Escola para não reduzir a renda familiar, mesmo que isso represente melhores chances no futuro decorrentes do maior nível educacional obtido ao participar do programa.

Assumindo que a criança recebe como salário os valores médios da amostra é possível exemplificar as escolhas das famílias das crianças que trabalham.

Considerando as crianças pobres de seis a quinze anos, se a criança estuda e trabalha, mas não recebe o Bolsa Escola, ganha R\$ 14 / mês. Então ela pode optar por participar do Bolsa Escola e deixar de trabalhar, e sua "renda" será de R\$ 15 / mês, ou se inscrever no programa e continuar trabalhando, aumentando sua renda para R $29 /$ mês ( $\mathrm{R} \$ 14$, que é a média de rendimento do trabalho parcial, mais R\$ 15 do Bolsa Escola).

Se essa criança não estuda, ganha em média R \$ 47 / mês. Se optar pelo Bolsa Escola, deixando o trabalho, deverá ganhar R\$ 15 / mês, R\$ 32 a menos que na situação inicial. Se optar pelo Bolsa Escola, trabalhando meio período, sua expectativa é de ganhar R\$ 29 / mês, R\$ 18 a menos que quando trabalhava em tempo integral.

Portanto a compensação financeira falha justamente na população-alvo do programa, o que é um problema sério. Neste caso a realocação do tempo da criança dependerá mais das preferências e do background familiar que das características do programa.

Análise similar pode ser realizada considerando as crianças das áreas urbanas e rurais separadamente, uma vez que, conforme pode ser observado na Tabela 7, os 
salários médios é significativamente menor no meio rural. É importante lembrar que tais médias foram calculadas levando-se em consideração o trabalho não remunerado, muito comum nas áreas rurais.

Tabela 7. Remuneração média mensal do trabalho principal, em reais, das crianças de 6 a 15 anos que estudam e que não estudam, segundo grupos de idade e situação de domicílio; Brasil, 2001.

\begin{tabular}{lcccccc}
\hline & \multicolumn{2}{c}{6 a 10} & \multicolumn{2}{c}{11 a 15} & \multicolumn{2}{c}{6 a 15} \\
\cline { 2 - 7 } & rural & urbano & rural & urbano & rural & urbano \\
\hline estuda & 0.6 & 10.4 & 6.4 & 36.3 & 4.9 & 32.3 \\
não estuda & 0.9 & 23.4 & 26.5 & 79.4 & 23.6 & 76.4 \\
\hline
\end{tabular}

Para encerrar a análise descritiva, o cruzamento das crianças que trabalham com as que recebem Bolsa Escola será retomado, focalizando a amostra definida pelas crianças de seis a quinze anos cuja renda familiar per capita é igual ou inferior a meio salário mínimo (em valores de 2001) por mês.

O Quadro 1 mostra que 4,5\% das crianças da amostra trabalham e recebem Bolsa Escola simultaneamente; entre os mais novos essa proporção é mais baixa que quando consideradas todas as crianças da amostra (2,3\%) e entre os mais velhos é mais alta $(6,9 \%)$. Considerando apenas as crianças de seis a quinze anos que trabalham, $37,5 \%$ recebem o benefício, e entre as que não trabalham este percentual é de $31 \%$. Quando são observadas somente as que recebem o benefício, nota-se que $14 \%$ das crianças trabalham, contra $11 \%$ que exercem alguma atividade laboral entre as que não recebem Bolsa Escola.

Ainda com base no Quadro 1, pode ser feita análise similar para cada grupo de idade. Assim, entre as crianças com dez anos ou menos, observa-se que 52\% das que trabalham recebem o benefício, contra $32 \%$ das que não trabalham. Quando consideradas apenas as que recebem Bolsa Escola 7\% estão trabalhando, e entre as que não recebem o benefício este percentual é de 3,2\%.

Entre as crianças que têm entre onze e quinze anos e trabalham, $34 \%$ 
participam do programa, e entre as que não trabalham a proporção dos participantes é de 29,8\%. Considerando as que recebem Bolsa Escola 22,6\% trabalha, e entre as que não recebem o benefício 19,3\% está ocupada.

De forma geral, cerca de $32 \%$ da população entre seis e quinze anos com renda per capita inferior a meio salário mínimo está inscrita em programas de renda mínima vinculado à educação, e $12 \%$ destas crianças fazem parte da população economicamente ativa e estão ocupadas.

\begin{tabular}{|c|c|c|c|c|c|c|c|c|c|}
\hline \multirow[b]{3}{*}{ trabalha } & \multicolumn{3}{|c|}{6 a 10 anos } & \multicolumn{3}{|c|}{11 a 15 anos } & \multicolumn{3}{|c|}{6 a 15 anos } \\
\hline & \multicolumn{2}{|c|}{$\begin{array}{c}\text { recebe bolsa } \\
\text { escola }\end{array}$} & \multirow[t]{2}{*}{ Total } & \multicolumn{2}{|c|}{$\begin{array}{l}\text { recebe bolsa } \\
\text { escola }\end{array}$} & \multirow[t]{2}{*}{ Total } & \multicolumn{2}{|c|}{$\begin{array}{c}\text { recebe bolsa } \\
\text { escola }\end{array}$} & \multirow[t]{2}{*}{ Total } \\
\hline & $\operatorname{sim}$ & \begin{tabular}{l|l|} 
não \\
\end{tabular} & & sim & não & & $\operatorname{sim}$ & não & \\
\hline \multicolumn{10}{|l|}{$\operatorname{sim}$} \\
\hline $\begin{array}{r}\% \text { do grupo de } \\
\text { idade }\end{array}$ & 2.3 & 2.1 & 4.5 & 6.9 & 13.4 & 20.3 & 4.5 & 7.6 & 12.1 \\
\hline$\%$ da linha & 52.1 & 47.9 & & 34.0 & 66.0 & & 37.5 & 62.5 & \\
\hline$\%$ da coluna & 7.0 & 3.2 & & 22.6 & 19.3 & & 14.2 & 11.1 & \\
\hline \multicolumn{10}{|l|}{ não } \\
\hline $\begin{array}{r}\% \text { do grupo de } \\
\text { idade }\end{array}$ & 30.8 & 64.7 & 95.5 & 23.7 & 55.9 & 79.7 & 27.4 & 60.5 & 87.9 \\
\hline$\%$ da linha & 32.3 & 67.7 & & 29.8 & 70.2 & & 31.2 & 68.8 & \\
\hline$\%$ da coluna & 93.0 & 96.8 & & 77.4 & 80.7 & & 85.8 & 88.9 & \\
\hline Total & 33.2 & 66.8 & 100.0 & 30.6 & 69.4 & 100.0 & 31.9 & 68.1 & 100.0 \\
\hline
\end{tabular}

Quadro 1 Percentual de crianças de 6 a 15 anos de idade que recebem e que não recebem Bolsa Escola segundo ocupação e grupos de idade; Brasil, 2001.

\subsection{Análise econométrica}

Para medir o impacto dos programas de Bolsa Escola no trabalho infantil foram adotadas duas estratégias: a primeira consiste em verificar o impacto dos programas na probabilidade de a criança trabalhar, utilizando um modelo próbite em que a variável dependente é um se a criança trabalha e zero se não trabalha; a segunda estratégia é verificar o impacto dos programas de Bolsa Escola sobre a oferta de horas de trabalho 
das crianças que estão trabalhando, e envolve estimar os parâmetros de uma regressão linear utilizando o método de mínimos quadrados, em que a variável dependente é o número de horas semanais trabalhadas. Todas as regressões são ponderadas pelo fator de expansão da amostra da PNAD.

As médias ponderadas das variáveis utilizadas nas regressões estão na Tabela 8. Considerando todas as crianças de seis a quinze anos da amostra, nota-se que a proporção das que trabalham é maior no meio rural, onde $26 \%$ exercem alguma atividade laboral, contra 6\% na área urbana. Além disso, no meio rural mais de $41 \%$ das crianças participam de programas de bolsa escola enquanto no meio urbano esta proporção é mais baixa, cerca de $28 \%$, e estas proporções não são muito alteradas quando se trata das crianças que trabalham $-42 \%$ e $30 \%$ em áreas rurais e urbanas, respectivamente.

Entretanto, embora a proporção de crianças que trabalham seja maior no meio rural, a jornada semanal de trabalho é mais longa em áreas urbanas. Assim, as crianças de seis a quinze anos que trabalham cumprem, em média, jornadas de 24,8 e 20,9 horas semanais na cidade e no campo, respectivamente.

Tabela 8. Média ponderada das variáveis utilizadas.

\begin{tabular}{lcccc}
\hline \multirow{2}{*}{\multicolumn{1}{c}{ Variáveis }} & \multicolumn{3}{c}{ Crianças de 6 a 15 anos } & \multicolumn{2}{c}{$\begin{array}{c}\text { Crianças de 6 a 15 anos que } \\
\text { trabalham }\end{array}$} \\
\cline { 2 - 5 } & Urbano & Rural & Urbano & Rural \\
\hline Trabalha & 0,0627 & 0,2639 & & \\
Horas Trabalhadas & & & 24,8229 & 20,9047 \\
Bolsa Escola & 0,2859 & 0,4188 & 0,3032 & 0,4261 \\
Idade da criança & 10,2086 & 10,3899 & 12,9519 & 12,2566 \\
Sexo & 0,4982 & 0,5181 & 0,6555 & 0,7048 \\
Preta & 0,0603 & 0,0402 & 0,0538 & 0,0341 \\
Branca & 0,3454 & 0,3382 & 0,3127 & 0,3068 \\
Amarela & 0,0021 & 0,0010 & 0,0051 & 0,0021 \\
Parda & 0,5921 & 0,6206 & 0,6283 & 0,6570 \\
Idade da mãe & 35,8333 & 37,2003 & 38,9087 & 39,7766 \\
Ln do rendimento da mãe ${ }^{\text {a }}$ & 5,5712 & 5,2162 & 4,9279 & 4,5714
\end{tabular}


Tabela 8. Média ponderada das variáveis utilizadas.

\begin{tabular}{|c|c|c|c|c|}
\hline \multirow[t]{2}{*}{ Variáveis } & \multicolumn{2}{|c|}{ Crianças de 6 a 15 anos } & \multicolumn{2}{|c|}{$\begin{array}{c}\text { Crianças de } 6 \text { a } 15 \text { anos que } \\
\text { trabalham }\end{array}$} \\
\hline & Urbano & Rural & Urbano & Rural \\
\hline Idade do pai & 41,3073 & 42,9934 & 43,8278 & 45,3926 \\
\hline Ln do rendimento do pai ${ }^{\text {a }}$ & 4,9693 & 4,5736 & 5,5405 & 5,2253 \\
\hline Rondonia & 0,0083 & & 0,0044 & \\
\hline Acre & 0,0039 & & 0,0047 & \\
\hline Amazonas & 0,0250 & & 0,0176 & \\
\hline Pará & 0,0517 & & 0,0705 & \\
\hline Amapá & 0,0023 & & 0,0011 & \\
\hline Tocantins & 0,0087 & 0,0147 & 0,0087 & 0,0126 \\
\hline Maranhão & 0,0520 & 0,0973 & 0,0877 & 0,1345 \\
\hline Piauí & 0,0187 & 0,0514 & 0,0239 & 0,0472 \\
\hline Ceará & 0,0743 & 0,0909 & 0,1107 & 0,0830 \\
\hline Rio Grande do Norte & 0,0202 & 0,0303 & 0,0277 & 0,0214 \\
\hline Paraíba & 0,0353 & 0,0422 & 0,0471 & 0,0304 \\
\hline Pernambuco & 0,0679 & 0,0969 & 0,0668 & 0,1245 \\
\hline Alagoas & 0,0250 & 0,0426 & 0,0372 & 0,0425 \\
\hline Sergipe & 0,0167 & 0,0175 & 0,0080 & 0,0188 \\
\hline Bahia & 0,0999 & 0,1851 & 0,1121 & 0,1781 \\
\hline Minas Gerais & 0,1040 & 0,1024 & 0,0982 & 0,0897 \\
\hline Espírito Santo & 0,0187 & 0,0192 & 0,0137 & 0,0183 \\
\hline Rio de Janeiro & 0,0604 & 0,0110 & 0,0226 & 0,0059 \\
\hline São Paulo & 0,1371 & 0,0385 & 0,0811 & 0,0120 \\
\hline Paraná & 0,0448 & 0,0542 & 0,0435 & 0,0641 \\
\hline Rio Grande do Sul & 0,0148 & 0,0197 & 0,0136 & 0,0191 \\
\hline Santa Catarina & 0,0390 & 0,0443 & 0,0426 & 0,0610 \\
\hline Mato Grosso do Sul & 0,0127 & 0,0076 & 0,0090 & 0,0036 \\
\hline Mato Grosso & 0,0136 & 0,0137 & 0,0105 & 0,0199 \\
\hline Goiás & 0,0323 & 0,0186 & 0,0328 & 0,0134 \\
\hline Distrito Federal & 0,0102 & 0,0018 & 0,0021 & \\
\hline Observações & 7.346 .157 & 3.733 .156 & 460.432 & 985.318 \\
\hline
\end{tabular}


A Tabela 9 mostra os resultados obtidos para as equações estimadas ${ }^{32}$. As colunas (1) e (3) apresentam as equações de oferta de trabalho na forma reduzida para as crianças de seis a quinze anos das áreas urbana e rural, respectivamente. Da mesma forma, as colunas (2) e (4) apresentam as equações do número de horas trabalhadas pelas crianças nas áreas urbana e rural, considerando apenas as crianças de seis a quinze anos que trabalham. Todas as regressões foram ponderadas pelo fator de expansão da amostra da PNAD. Além disso, nota-se que praticamente todas as variáveis foram estatisticamente significativas a $1 \%$.

Para as equações de oferta de trabalho, utilizadas para medir a probabilidade de a criança trabalhar, foi aplicado o teste da razão de verossimilhança, para testar se os dados de crianças de áreas urbana e rural deveriam ser analisados separadamente. No caso das equações de número de horas trabalhadas, em que se verifica o impacto dos programas de bolsa escola sobre o número de horas ofertadas pelas crianças que trabalham, foi aplicado o teste $\mathrm{F}$, com o mesmo propósito. Os dois testes foram altamente significativos, indicando que os dados devem ser analisados separadamente.

A variável de principal interesse, Bolsa Escola, é estatisticamente significativa a $1 \%$ em todas as equações apresentadas na Tabela 9. Entretanto, nas colunas (1) e (3) o sinal obtido não foi o esperado, já que era esperado que um aumento no programa diminuísse o trabalho de crianças.

Assim, participar de programas de Bolsa Escola está positivamente relacionado ao trabalho infantil, aumentando em $0,28 \%$ e 3,5\% a probabilidade de a criança trabalhar na área urbana e na área rural, respectivamente. Apesar de o impacto do Bolsa Escola ser pequeno na área urbana, este resultado difere do encontrado em Cardoso \& Souza (2003), em que o impacto da transferência de renda na probabilidade de crianças de dez a quinze anos trabalharem é zero.

\footnotetext{
${ }^{32} \mathrm{Na}$ área rural da região norte, apenas são coletadas informações para o Estado do Tocantins.
} 
Tabela 9. Equações de trabalho de crianças de 6 a 15 anos de famílias com renda per capita mensal igual ou inferior a meio salário mínimo.

\begin{tabular}{|c|c|c|c|c|c|c|c|c|}
\hline \multirow[b]{2}{*}{ Variáveis } & \multicolumn{4}{|c|}{ Urbano } & \multicolumn{4}{|c|}{ Rural } \\
\hline & $\begin{array}{c}\text { Trabalha } \\
\text { (1) }\end{array}$ & & $\begin{array}{c}\text { Horas de } \\
\text { trabalho } \\
(2)\end{array}$ & & $\begin{array}{c}\text { Trabalha } \\
\text { (3) }\end{array}$ & & $\begin{array}{c}\text { Horas de } \\
\text { trabalho } \\
(4)\end{array}$ & \\
\hline Bolsa Escola & 0,0028 & $*$ & $-3,3781$ & $*$ & 0,0355 & $*$ & $-2,7062$ & $*$ \\
\hline Idade da criança & 0,0145 & $*$ & 2,1876 & $*$ & 0,0618 & $*$ & 1,4515 & $*$ \\
\hline Sexo & 0,0271 & $*$ & $-1,0184$ & $*$ & 0,1941 & $*$ & 2,2953 & $*$ \\
\hline Branca & 0,0064 & $*$ & $-1,9676$ & $*$ & 0,0403 & $*$ & $-3,0757$ & $*$ \\
\hline Amarela & 0,0597 & $*$ & $-7,3382$ & $*$ & 0,1829 & $*$ & 2,1113 & $*$ \\
\hline Parda & 0,0040 & $*$ & $-1,0476$ & $*$ & 0,0594 & $*$ & $-1,4578$ & $*$ \\
\hline Idade da mãe & 0,0002 & $*$ & $-0,0336$ & $*$ & 0,0025 & $*$ & 0,0446 & $*$ \\
\hline $\begin{array}{l}\text { Ln do rendimento da } \\
\text { mãe }{ }^{a}\end{array}$ & $-0,0416$ & $*$ & $-7,7074$ & $*$ & $-0,1245$ & $*$ & $-12,1111$ & $*$ \\
\hline Idade do pai & 0,0008 & $*$ & 0,1479 & $*$ & 0,0046 & $*$ & 0,0603 & $*$ \\
\hline $\begin{array}{l}\text { Ln do rendimento do } \\
\text { pai }{ }^{\text {a }}\end{array}$ & $-0,0822$ & $*$ & $-6,4568$ & $*$ & $-0,4376$ & $*$ & $-4,1268$ & $*$ \\
\hline Rondonia & 0,0036 & $*$ & $-0,5165$ & $* *$ & & & & \\
\hline Acre & 0,0552 & $*$ & $-2,0116$ & $*$ & & & & \\
\hline Amazonas & 0,0230 & $*$ & 0,5922 & $*$ & & & & \\
\hline Pará & 0,0772 & $*$ & 2,1853 & $*$ & & & & \\
\hline Amapá & $-0,0005$ & & $-19,9815$ & $*$ & & & & \\
\hline Tocantins & 0,0427 & $*$ & 6,0795 & $*$ & $-0,0128$ & $*$ & 2,8540 & $*$ \\
\hline Maranhão & 0,0299 & $*$ & $-3,1431$ & $*$ & 0,0129 & $*$ & 1,3675 & $*$ \\
\hline Piauí & 0,0118 & $*$ & $-9,4769$ & $*$ & $-0,0976$ & $*$ & $-1,5164$ & $*$ \\
\hline Ceará & 0,0187 & $*$ & $-4,0552$ & $*$ & $-0,0988$ & $*$ & 1,7202 & $*$ \\
\hline Rio Grande do Norte & 0,0116 & $*$ & $-2,9465$ & $*$ & $-0,1243$ & $*$ & 1,3641 & $*$ \\
\hline Paraíba & 0,0085 & $*$ & $-5,7440$ & $*$ & $-0,1473$ & $*$ & $-0,8228$ & $*$ \\
\hline Alagoas & 0,0149 & $*$ & 1,5521 & $*$ & $-0,0854$ & $*$ & 3,7218 & $*$ \\
\hline Sergipe & $-0,0190$ & $*$ & $-6,9506$ & $*$ & $-0,0741$ & $*$ & 0,6610 & $*$ \\
\hline Bahia & 0,0025 & $*$ & $-4,0992$ & $*$ & $-0,0788$ & $*$ & $-0,6809$ & $*$ \\
\hline Minas Gerais & 0,0523 & $*$ & 0,3690 & $*$ & 0,0464 & $*$ & 5,3998 & $*$ \\
\hline Espírito Santo & 0,0515 & $*$ & 6,9901 & $*$ & 0,1077 & $*$ & 5,5665 & $*$ \\
\hline Rio de Janeiro & 0,0114 & $*$ & 1,4567 & $*$ & 0,0115 & $*$ & 11,0753 & $*$ \\
\hline São Paulo & 0,0236 & $*$ & 4,1032 & $*$ & $-0,1152$ & $*$ & 7,4362 & $*$ \\
\hline Paraná & 0,0548 & $*$ & $-1,3550$ & $*$ & 0,1653 & $*$ & 7,9205 & $*$ \\
\hline Rio Grande do Sul & 0,0726 & $*$ & $-3,6952$ & $*$ & 0,2713 & $*$ & 4,4663 & $*$ \\
\hline Santa Catarina & 0,0485 & $*$ & $-0,8106$ & $*$ & 0,1598 & $*$ & 9,3848 & $*$ \\
\hline
\end{tabular}


Tabela 9. Equações de trabalho de crianças de 6 a 15 anos de famílias com renda per capita mensal igual ou inferior a meio salário mínimo.

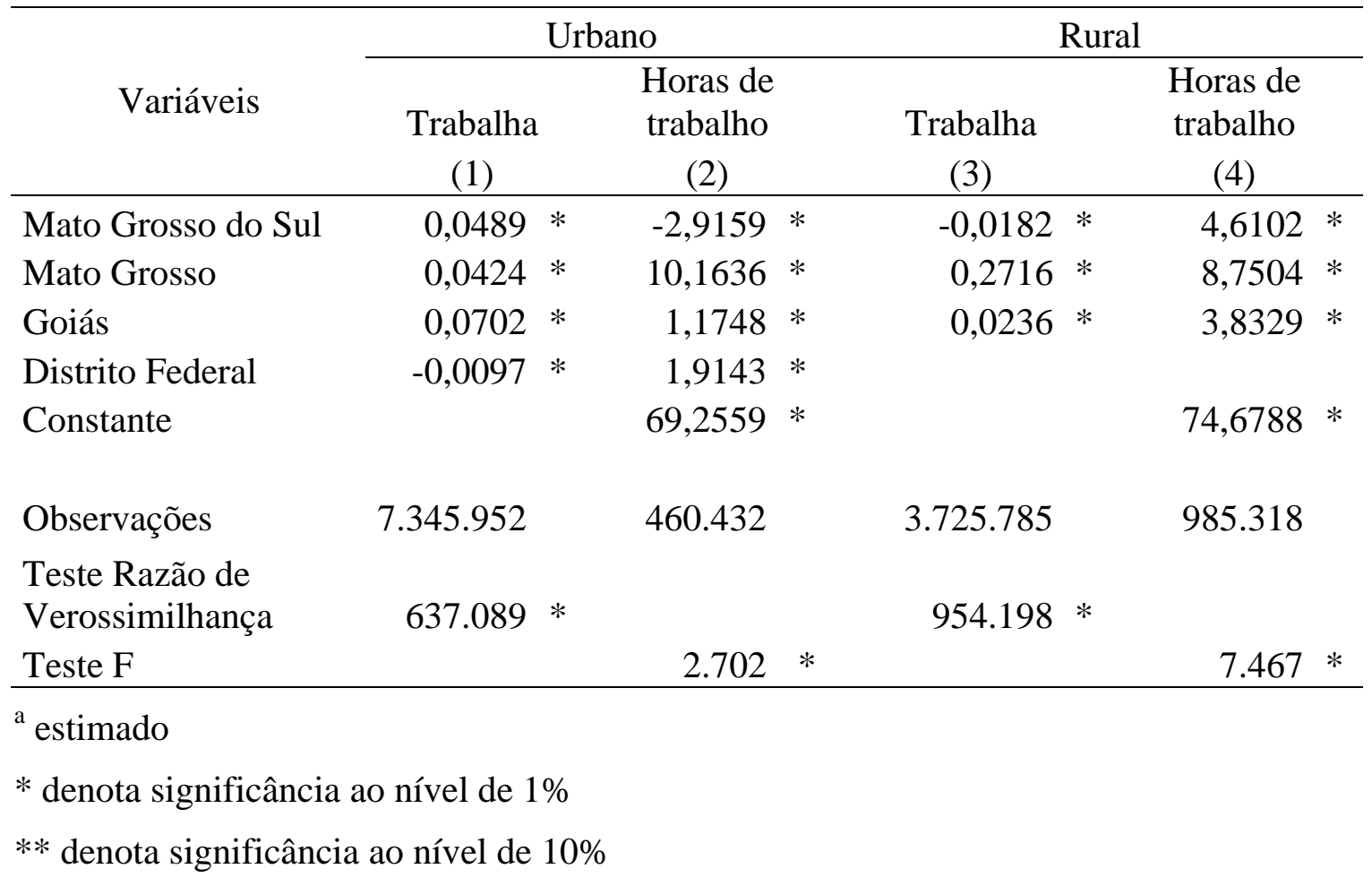

Nas colunas (2) e (4), entretanto, observa-se que o impacto dos programas de Bolsa Escola sobre o número de horas trabalhadas é negativo, conforme esperado, tanto na área urbana quanto na área rural. Então participar do programa diminui em 3,37 horas a jornada de trabalho semanal das crianças que trabalham na área urbana, enquanto na área rural essa redução é de aproximadamente 2,7 horas.

Dois aspectos merecem destaque neste ponto. Primeiro, a magnitude da redução na jornada mensal é compatível com casos em que a criança já trabalhava em meio período, e não com os que o trabalho era integral. Isso corrobora a análise feita em seção anterior, em que se percebe que crianças que trabalham em período integral e não estudam não teriam incentivo financeiro para participar dos programas de Bolsa Escola, pois ganham mais, em média, no mercado de trabalho. Em outras palavras, o trabalho em período integral corresponde a uma jornada de 40 horas semanais; a redução desta jornada em algo em torno de três horas significa que a criança que trabalha em período 
integral - e que provavelmente não freqüenta a escola - passaria a trabalhar 37 horas semanais, ou pouco mais de seis horas diárias de segunda a sábado, sobrando pouco tempo para a escola. Considerando a jornada média semanal de crianças que não estudam, discutida em seção anterior, participar de um programa Bolsa Escola reduziria a jornada semanal de 35 para cerca de 31,6 e de 33 para 30,3 horas semanais nas áreas urbana e rural, respectivamente, o que representa uma redução de 5,8 ou 5,5 para pouco mais de cinco horas diárias, seis dias por semana, em qualquer caso. Além disso, a análise descritiva indica que os salários recebidos pela criança que ocupa todo o seu tempo com trabalho são, em média, superiores à soma dos rendimentos provenientes do trabalho em tempo parcial e dos programas de Bolsa Escola. Deve-se destacar também que, uma vez que as exigências de matrícula e freqüência escolar devem ser atendidas para que o benefício seja pago, é natural que a jornada de trabalho diminua, mas se a criança já freqüentava a escola enquanto trabalhava essa redução deve ser pequena.

Porém, ainda há o fato de o programa estar positivamente relacionado com a probabilidade de trabalho infantil. Dadas as características da amostra e assumindo que as famílias vão maximizar sua utilidade por meio da maximização da renda total, é possível inferir que, quanto maior o desejo de mobilidade social ou até mesmo de atingir condições mínimas de sobrevivência, serão adotadas todas as estratégias possíveis. Assim, todos os membros do domicílio irão trabalhar, inclusive as crianças, e a família tentará participar dos programas sociais voltados a essa parcela da população, como os de Bolsa Escola, por exemplo, num esforço conjunto para deixar a pobreza. Esse desejo de melhorar de vida, que pode ser denominado de "ambição" da família, da forma como é sugerido, tem um efeito positivo sobre o trabalho infantil.

Entretanto, essa "ambição" ou desejo da família de melhorar de vida não está entre as variáveis explicativas do modelo proposto, configurando um caso de variável omitida. Sendo assim, conclui-se que o efeito desta variável omitida sobre o trabalho infantil, que é positivo, está sendo captado pela variável Bolsa Escola, cujo efeito presume-se negativo e menor que o da ambição da família.

Essa hipótese parece ser bastante razoável, principalmente se considerados os 
resultados obtidos para as outras variáveis em todas as equações e para a variável Bolsa Escola nas equações de número de horas trabalhadas, que são os esperados, como será discutido adiante. Neste caso, o mais indicado seria a utilização de uma variável proxy para a ambição da família que, no entanto, não foi encontrada.

Ainda em relação às características das crianças, a Tabela 9 mostra que quanto mais velha a criança mais ela trabalha, sendo que um ano adicional significa aumentar em $1,45 \%$ e $6,18 \%$ a chance de estar trabalhando e em 2,19 e 1,45 horas mensais a jornada de trabalho, nas áreas urbana e rural, respectivamente. Quanto às estimativas das variáveis utilizadas para captar o efeito das raças, nota-se que a probabilidade de estar trabalhando é maior, em relação aos negros, entre amarelos, brancos e pardos. Porém, dado que a criança trabalha, os negros só têm jornada menor que amarelos na área rural, trabalhando mais horas semanais que brancos e pardos da área rural e que todos os outros na área urbana.

Meninos têm maior probabilidade de estar trabalhando que meninas, mas dado que a criança está trabalhando, meninas trabalham mais que meninos na área urbana enquanto na área rural ocorre o inverso. A probabilidade de um menino trabalhar é, em relação às meninas, 2,7\% maior na área urbana e 19\% maior na área rural; da mesma forma, os meninos trabalham menos que as meninas cerca de uma hora por semana na área urbana e mais que elas 2,29 horas semanais na área rural.

Quanto às características do pai e da mãe, utilizadas para captar os efeitos de background familiar, observa-se, ainda na Tabela 9, que quanto mais velhos são os pais, maior é a probabilidade de a criança trabalhar, tanto na área urbana quanto na rural. Este resultado está de acordo com a idéia de que as pessoas mais velhas começaram a trabalhar mais cedo, e tendem a valorizar o trabalho precoce. Além disso, o impacto da idade do pai é maior que o da idade da mãe, indicando que os pais mais velhos valorizam mais o trabalho precoce que as mães mais velhas.

Uma vez que a criança trabalha, quanto mais velho é o pai, maior a jornada semanal dos filhos e esse mesmo mecanismo é observado para as mães da área rural, embora o impacto da idade do pai seja maior que o da idade da mãe. Na área urbana, no 
entanto, quanto mais velha é a mãe, menor é a oferta de horas semanais de trabalho da criança.

O rendimento dos adultos também apresentou os sinais esperados, ou seja, quando os salários dos pais aumentam, a probabilidade de a criança trabalhar, assim como a sua jornada de trabalho, diminui. Além disso, o efeito do salário dos pais é maior que o do salário das mães, e é maior na área rural que na área urbana quando se trata da probabilidade da criança trabalhar, mas o efeito do salário das mães é maior que o do salário dos pais na hora de decidir quantas horas as crianças vão trabalhar por semana.

Assim, como é possível observar na coluna (1), a uma variação positiva no logaritmo do salário da mãe corresponde uma redução de 4,16\% na probabilidade de a criança trabalhar, e a mesma variação no caso dos pais diminui em 8,22\% a probabilidade de trabalho na área urbana.

Fazendo a mesma análise considerando a jornada de trabalho das crianças da área urbana, notas-se por meio da coluna (2) que um aumento adicional no logaritmo do salário da mãe reduz em cerca de 7,7 horas a jornada mensal de trabalho da criança, enquanto a mesma variação no logaritmo do salário do pai diminui a jornada em 6,45 horas.

Como dito anteriormente, na área rural o impacto do rendimento dos pais é maior que na área urbana. Assim, como pode ser observado nas colunas (3) e (4), um aumento adicional no logaritmo do salário da mãe reduz em 12,45\% a probabilidade de trabalho e em aproximadamente de 12 horas a jornada mensal das crianças. A mesma variação, no caso dos pais, reduz em 43,7\% a probabilidade de a criança trabalhar e em cerca de 4 horas sua jornada mensal. A elevada magnitude do efeito da renda do pai sobre o trabalho infantil nas áreas rurais deve ser decorrência, principalmente, da estrutura desses domicílios, como, por exemplo, o pai ser o chefe da família e responsável por garantir o seu sustento enquanto a mãe cuida da casa e dos filhos, tendo um papel secundário no provimento dos bens de consumo no domicílio.

Portanto, conclui-se que os programas de Bolsa Escola reduzem a jornada de 
trabalho das crianças, mas pouco pode ser dito sobre o impacto na probabilidade de ingresso no mercado de trabalho. O salário do pai tem impacto maior que o salário da mãe na probabilidade da criança trabalhar, mas dado que a criança trabalha o salário da mãe tem mais influência que o do pai na decisão do número de horas semanais ofertado; nas áreas rurais o efeito da renda é mais expressivo que na área urbana, tanto quando se trata da probabilidade de a criança trabalhar como quando as horas de trabalho são consideradas. Confirma-se também que meninos têm mais chances de estar trabalhando que meninas, na área rural meninos trabalham mais horas por semana que meninas, mas na área urbana as meninas têm jornada semanal mais longa que a dos meninos, e que crianças da área rural trabalham mais que as da área urbana. 


\section{CONCLUSÕES}

O objetivo deste trabalho é fazer uma avaliação ex-post do impacto dos programas de Bolsa Escola sobre o trabalho infantil no Brasil. Para tanto, foram utilizados os dados da Pesquisa Nacional por Amostra de Domicílios (PNAD) de 2001, que traz encarte especial sobre saúde e segurança no trabalho da população de cinco a dezessete anos de idade.

As estratégias adotadas foram: i) estimar um modelo próbite em que a variável dependente assume o valor um se a criança trabalha e zero se não trabalha, e entre as variáveis explanatórias tradicionalmente encontradas na literatura incluir uma variável binária indicativa da participação ou não de programas de renda mínima vinculada à educação; e ii) estimar uma equação de número de horas trabalhadas por mínimos quadrados para as crianças que trabalham, em que a variável dependente é o número de horas semanais normalmente trabalhadas e as variáveis explicativas são as mesmas do modelo próbite.

A amostra foi composta por crianças de seis a quinze anos de idade pertencentes a famílias com renda per capita mensal igual ou inferior a noventa reais, que corresponde a meio salário mínimo em 2001. Essa é a população alvo dos programas de Bolsa Escola existentes no Brasil atualmente. Foram estimadas equações separadas para crianças das áreas urbana e rural.

As estimativas encontradas foram estatisticamente significativas e em sua maioria apresentaram os sinais esperados. Assim, de forma geral, quanto mais nova é a criança, ou quanto mais novos forem os pais, ou quanto maior o salário estimado dos adultos, menor será a probabilidade de as crianças trabalharem e a jornada mensal de trabalho. Meninas trabalham menos que os meninos, assim como crianças da área 
urbana em relação às da área rural.

Os resultados encontrados mostram também que os salários dos pais influenciam mais no trabalho da criança do que as das mães quando se trata da probabilidade de a criança ingressar no mercado do trabalho, mas dado que a criança trabalha os salários das mães influenciam mais na decisão de quantas horas de trabalho infantil serão ofertadas. Assim, enquanto um aumento adicional no salário das mães (em logaritmo) reduz em $4,16 \%$ e $12,45 \%$ a probabilidade de a criança trabalhar nas áreas urbana e rural, respectivamente, o impacto da mesma variação no salário do pai sobre a chance de a criança estar trabalhando é de 8,22\% na área urbana e 43,76\% na área rural. Este último resultado chama a atenção para a influência de componentes culturais e da própria estrutura familiar na decisão de alocação do tempo das crianças.

Os resultados encontrados para a variável de principal interesse, que é a participação em programas de Bolsa Escola, foram pouco conclusivos, mas dão algumas pistas sobre o comportamento das famílias nas decisões de alocação do tempo de seus membros, que maximizam sua utilidade.

O impacto dos programas de Bolsa Escola no número de horas que as crianças trabalham por semana foi o esperado: crianças que participam deste tipo de programa trabalham cerca de 3,4 horas a menos que as que não recebem o benefício no meio urbano, e aproximadamente 2,7 horas a menos no meio rural. A magnitude dos coeficientes estimados é condizente com a hipótese formulada na análise descritiva dos dados, de que crianças que trabalham em período integral têm menos incentivos a participar de programas de Bolsa Escola do que as que trabalham meio período, pois o valor das bolsas não compensa o seu custo de oportunidade, representado pelos salários de mercado. Já as crianças que trabalham no período complementar ao da escola têm incentivo a participar do programa como forma de aumentar seus rendimentos mensais, sem, no entanto, alterar seu comportamento.

A análise descritiva dos dados mostra que se a criança não estuda e, portanto, trabalha em período integral, seu salário é, em média, superior à soma do salário médio recebido pelo trabalho em tempo parcial e ao benefício pago pelos programas de Bolsa 
Escola, indicando que o custo de oportunidade dessa criança no mercado de trabalho não é compensado pelo valor da bolsa. Quando a criança já divide o seu tempo entre trabalho e estudo, participar do programa aumenta seu rendimento mensal porque adiciona ao salário o valor da bolsa, mas não dá incentivos para deixar o mercado de trabalho.

Por outro lado, a análise econométrica mostra que o impacto, para as crianças que trabalham, de participar de um programa de renda mínima vinculada à educação no número de horas semanais de trabalho é de uma redução em cerca de três horas. Sendo assim, se a criança trabalhava e não estudava, com uma jornada de trabalho de 34 horas semanais, em média, passaria, com o Bolsa Escola, a trabalhar pouco mais de 30 horas por semana, ou cerca de cinco horas por dia de segunda a sábado, sobrando pouco tempo para as atividades escolares. Já a criança que dividia o seu tempo entre trabalho e estudo antes de participar do programa, trabalhando cerca de 21 horas por semana, com a bolsa passará a trabalhar cerca de três horas por dia, e poderá dedicar a maior parte do seu tempo para o estudo.

Dessa forma, as crianças que trabalham e estudam continuam exercendo as duas atividades quando são beneficiárias do programa, aumentando os seus rendimentos ao participar do Bolsa Escola. Já as que trabalham em período integral e não freqüentam as aulas não têm incentivo financeiro de curto prazo para participar desses programas, pois passariam a receber menos do que na situação inicial, mesmo que não parassem de trabalhar para estudar. Sendo assim, a baixa magnitude do impacto do Bolsa Escola na redução da jornada de trabalho das crianças pode ser explicada por uma falha do programa em atingir seu principal público-alvo.

No caso das equações de trabalho na forma reduzida, estimadas para os modelos próbite, a variável Bolsa Escola apresentou sinal positivo tanto na regressão com os dados da área urbana quanto da área rural, e foi estatisticamente significativa nos dois casos. Estes resultados, entretanto, não estariam representando uma relação direta entre as variáveis, mas sim características não observáveis das famílias. A hipótese mais razoável é que a família, ao maximizar sua utilidade, e conseqüentemente sua renda, adotará o maior número de estratégias possíveis quanto maiores forem o seu desejo de 
mobilidade social e a disposição de seus membros em colaborar para atingir tal objetivo. Tais estratégias incluem o trabalho de todos as pessoas do domicílio, inclusive das crianças, e a participação no maior número possível de programas sociais que gerem renda ou benefícios. O desejo da família de sair da situação de pobreza terá, dessa forma, impacto positivo sobre o trabalho infantil, pois pais que vão em busca de programas sociais também são aqueles que colocam os filhos no mercado de trabalho.

Considera-se, então, que o desejo da família de melhorar de vida é a variável não observável omitida do modelo, e que seu efeito positivo é maior que o efeito da variável Bolsa Escola que, presume-se, seja negativo. Assim, a participação nos programas de renda mínima vinculada à educação, incluída no modelo, estaria captando na verdade o efeito da variável omitida.

Como os resultados das demais variáveis das características da família e da criança foram os esperados, bem como o sinal da variável Bolsa Escola nas regressões de horas de trabalho, a hipótese da variável omitida torna-se bastante razoável.

Assim, conclui-se que os programas de Bolsa Escola contribuem para a redução da jornada de trabalho das crianças de seis a quinze anos pertencentes a famílias que têm renda per capita inferior a meio salário mínimo, mas nada pode ser dito em relação ao impacto deste tipo de política social sobre a decisão de trabalhar ou não. 


\section{REFERÊNCIAS BIBLIOGRÁFICAS}

ANKER, R. Conceptual and research frameworks for the economics of child labour and its elimination. Genebra: ILO, 2000. 48p. (ILO/IPEC Working Paper)

ANUATTI NETO, F.; FERNANDES, R.; PAZELLO, E.T. Poverty alleviaton policies: the problem of targerting when income is not directly observed. Ribeirão Preto: FEARP/USP, 2001. 13p. (Textos para Discussão. Série Economia, 17)

BARROS, R.P.; MENDONÇA, R.S.P.; VELAZCO, T. A pobreza é a principal causa do trabalho infantil no Brasil urbano? Rio de Janeiro: IPEA, 1994. 26p.

BASU, K. Child labor: cause, consequence, and cure, with remarks on international labor standards. Journal of Economic Literature, v.37, n.3, p.1083-1119, Sep. 1999.

BASU, K.; VAN, P.H. Economics of child labor. The American Economic Review, v.88, n.3, p.412-427, June 1998.

BERNDT, E. 1991. The practice of econometrics: classic and contemporary. Massachusets: Addison-Wesley Publishers, 1991. 702p.

BESLEY, T. Means testing versus universal provision in poverty alleviation programmes. Economica, v.57, n.225, p.119-129, Feb. 1990.

BHALOTRA, S. Is child work necessary? Londres: LSE Suntory Toyota, Development Economics Research Programme, 2001. 40p. (Paper Series, 26)

BOURGUIGNON, F.; FERREIRA, F.H.G.; LEITE, P.G. Ex-ante evaluation of conditional cash transfer programs: the case of bolsa escola. Michigan: The William Davidson Institute, 2002. 31p. (Working Paper, 516) 
BRASIL. Leis, decretos, etc. Lei 8.069 de 13 de julho de 1990. http://www.presidencia.gov.br/ccivil_03/Leis/L8069.htm (12 nov. 2003)

BRASIL. Ministério da Assistência e Promoção Social. Relatório de gestão. http://www.assistenciasocial.gov.br/iframe/downloads/publicacoes/relatorio_2001/R el2001_01a30.pdf (16 abr. 2003)

BRASIL. Presidência da República. Trabalho infantil no Brasil: questões e políticas. Brasília: Presidência da República, 1998. 78p.

CARDOSO, E.; SOUZA, A.P. The impact of income transfers on child labor and school attendance in Brazil. São Paulo: USP, 2003. http://www.econ.fea.usp.br/elianacardoso/ECONBRAS/cardoso-souza.pdf (22 out. 2003)

CAMARGO, J.M.; FERREIRA, F.H.G. O Benefício Social Único: uma proposta de reforma da política social no Brasil. Rio de Janeiro: PUC, Depto. Economia, 2001. 82p. (Texto para Discussão, 443)

GALLI, R. The economic impact of child labour. Genebra: ILO Decent Work Research Programme, 2001. 26p. (Discussion Paper, 128)

GREENE, W. Econometric analysis. 3.ed. New Jersey: Prentice Hall, 1997. 791p.

GRIFFITHS, W.E.; HILL, R.C.; JUDGE, G.G. Learning and practicing econometrics. New York: John Wiley \& Sons, 1993. 866p.

GROOTAERT, C.; PATRINOS, H. The policy analysis of child labor: a comparative study. Washington: The World Bank, 1998. 245p.

INTERNATIONAL LABOUR ORGANIZATION. Child labour: targeting the intolerable. Genebra: ILO, 1998. 123p.

INTERNATIONAL LABOUR ORGANIZATION. Every child counts: new global estimates on child labour. Genebra: ILO, 2002. 51p.

INSTITUTO BRASILEIRO DE GEOGRAFIA E ESTATÍSTICA. Pesquisa nacional de amostra por domicílios: 2001. Rio de Janeiro: IBGE, 2003.

FERBER, R.; HIRSCH, W.Z. Social experimentation and economic policy: a survey. Journal of Economic Literature, v.16, n.4, p.1379-1414, Dec. 1978. 
FERRO, A.R.; KASSOUF, A.L. Impacto do aumento da idade mínima de ingresso no mercado de trabalho sobre a população brasileira de 14 e 15 anos (compact disc). In: CONGRESSO BRASILEIRO DE ECONOMIA E SOCIOLOGIA RURAL, 41., Juiz de Fora, 2003. Anais. Brasília: SOBER, 2003.

FRIEDLANDER, D.; ROBINS, P.K. Evaluating program evaluations: new evidence on commonly used nonexperimental methods. The American Economic Review, v.85, n.4, p.923-937, Sep. 1995.

HECKMAN, J.J.; SMITH, J.A. Assessing the case for social experiments. Journal of Economic Perspectives, v.9, n.2, p.85-110, Spring 1995.

JAFAREY, S.; LAHIRI, S. Child labor: theory, policy and evidence. World Economics, v.2, n.1, p.69-93, Jan./Mar. 2001.

JUDGE, G.G.; HILL, R.C.; GRIFFITHS, W.E.; LÜTKEPOHL, H.; LEE, T. Introduction to the theory and practice of econometrics. New York: John Wiley \& Sons, 1988. 1019p.

KASSOUF, A.L. Aspectos sócio-econômicos do trabalho infantil no Brasil. Brasília: Ministério da Justiça, 2002. 124p.

KASSOUF, A.L. Trabalho infantil: escolaridade x emprego. Economia, v.2, n.2, p.549-586, jul./dez. 2001.

MEDICI, A.C.; BRAGA, J.C.S. Políticas sociais e dinâmica econômica (elementos para uma reflexão). Planejamento e Políticas Públicas, n.10, p.33-89, dez. 1993.

NIELSEN, H.S.; DUBEY, A. Child labor: a microeconomic perspective. Århus: Aarhus School of Business, 2001. 22p. (Department of Economics Papers, 01-10)

PERES, A.; BENEDICTO, N. A caminho da escola: 10 anos de luta pela erradicação do trabalho infantil no Brasil. Rio de Janeiro: Instituto Souza Cruz, 2003. 132p.

RAVALLION, M.; WODON, Q. Does child labour displace schooling? evidence on behavioural responses to an enrollment subsidy. The Economic Journal, v.110, n.462, p.C158-C175, Mar. 2000.

ROCHA, S. Applying minimum income programs in Brazil two case studies: Belém and Belo Horizonte. Rio de Janeiro: IPEA, 2000. 19p. (Texto para Discussão, 746) 
SABOIA, A.L.; BREGMAN, S. R. Evolução da taxa de atividade de crianças e adolescentes no Brasil urbano - 1970 A 1990. In: ENCONTRO NACIONAL ABET, 3., São Paulo, 1993. Anais. São Paulo: ABET, 1993. v.1, p.193-226.

SABOIA, J.; ROCHA, S. An evaluation methodology for minimum income programmes in Brazil. Genebra: ILO, 2002. 27p.

SCORZAFAVE, L.G.; MENEZES-FILHO, N.A. Participação feminina no mercado de trabalho brasileiro: evolução e determinantes. Pesquisa e Planejamento Econômico, v.31, n.3, p.441-478, dez. 2001.

SCHULTZ, T.P. School subsidies for the poor: evaluating the mexican Progresa poverty program. New Haven: Yale University, 2001. 45p. (Economic Growth Center Discussion Paper, 834)

VILELA, R.B.V. O trabalho infantil no mundo. Mercado de Trabalho. Conjuntura e Análise, n.8, p.9-11, jul. 1998.

WORLD BANK. Brazil: as assessment of the Bolsa Escola programs. http://wwwwds.worldbank.org/servlet/WDSContentServer/WDSP/IB/2001/04/24/000094946_ 01041107221120/Rendered/PDF/multiOpage.pdf (15 abr. 2003)

YAP, Y.; SEDLACEK, G.; ORAZEM, P.F. Limiting child labor through behaviorbased income transfers: an experimental evaluation of the PETI program in rural Brazil. http://poverty.worldbank.org/files/11375_orazem-peti-brazil.pdf (17 Mar. 2003) 


\begin{abstract}
APÊNDICE
O procedimento de Heckman e as estimativas dos salários dos pais
\end{abstract}




\section{APÊNDICE - O procedimento de Heckman e as estimativas dos salários dos pais.}

Nesta seção é apresentado o procedimento formalizado por Heckman, utilizado neste estudo para estimar os salários de pais e mães. Maiores detalhes podem ser obtidos em Greene (1997), Griffiths et.al. (1993) ou Judge et.al. (1988).

Os dois produtos da análise são a oferta de trabalho $(z)$ e o salário $(y)$ dos indivíduos. O processo econométrico baseia-se no modelo de seletividade amostral ou incidentalmente truncado.

Consideram-se duas equações: i) equação de salários; e ii) equação da oferta de trabalho. Observa-se que a segunda equação descreve a oferta de trabalho, entretanto essa variável só é observada quando o indivíduo está trabalhando, ou seja, quando o salário de mercado é maior que o salário de reserva. Assim, a variável oferta de trabalho é incidentalmente truncada.

A equação que descreve a seletividade amostral é

$$
z_{i}^{*}=\gamma \boldsymbol{w}_{i}+u_{i}
$$

e a equação de principal interesse é:

$$
y_{i}=\boldsymbol{\beta}^{\prime} \boldsymbol{x}_{i}+\varepsilon_{i}
$$

A regra da amostra é que a oferta de trabalho $z_{i}$ só é observada quando $z_{i}{ }^{*}$ for maior que zero. Assumindo que $u_{i}$ e $\varepsilon_{i}$ têm distribuição normal com média zero e correlação $\rho$, tem-se o modelo:

$$
\begin{aligned}
& E\left[y_{i} \mid y_{i} \text { é observado }\right]=E\left[y_{i} \mid z_{i}{ }^{*}>0\right]=E\left[y_{i} \mid u_{i}>-\boldsymbol{\gamma}^{\prime} \boldsymbol{w}_{\boldsymbol{i}}\right]=\boldsymbol{\beta}^{\prime} \boldsymbol{x}_{\boldsymbol{i}}+E\left[\varepsilon i \mid u i>-\boldsymbol{\gamma}^{\prime} \boldsymbol{w}_{\boldsymbol{i}}\right] \\
& =\boldsymbol{\beta}^{\prime} \boldsymbol{x}_{\boldsymbol{i}}+\rho \sigma_{\varepsilon} \lambda_{i}\left(\alpha_{u}\right)=\beta^{\prime} \boldsymbol{x}_{\boldsymbol{i}}+\beta_{\lambda} \lambda_{i}\left(\alpha_{u}\right) \\
& \text { onde: } \quad \alpha_{u}=-\boldsymbol{\gamma}^{\prime} \boldsymbol{w}_{\boldsymbol{i}} / \sigma_{u} \\
& \text { e } \quad \lambda\left(\alpha_{u}\right)=\phi\left(\boldsymbol{\gamma}^{\prime} \boldsymbol{w}_{\boldsymbol{i}} / \sigma_{u}\right) / \Phi\left(\boldsymbol{\gamma}^{\prime} \boldsymbol{w}_{\boldsymbol{i}} / \sigma_{u}\right) .
\end{aligned}
$$

Então, 


$$
y_{i} \mid z_{i}^{*}>0=E\left[y_{i} \mid z_{i}^{*}>0\right]+v_{i}=\beta^{\prime} x_{i}+\beta_{\lambda} \lambda_{i}\left(\alpha_{u}\right)+v_{i}
$$

Assim, utilizar MQO para estimar os salários apenas para os indivíduos que trabalham produziria estimativas inconsistentes de $\beta$, pois configuraria um caso de omissão de variáveis. Fazer a regressão por mínimos quadrados de $y$ em função de $x$ e $\lambda$, por sua vez, produziria estimativas consistentes.

Resumindo, no procedimento de Heckman estima-se a primeira equação (modelo próbite cuja variável dependente é 1 se a pessoa participa do mercado de trabalho e 0 se não participa) por máxima verossimilhança para obter as estimativas dos parâmetros $\gamma$. Para cada observação na amostra selecionada, calcula-se $\hat{\lambda}_{i}=\phi\left(\hat{\gamma}^{\prime} w_{i}\right) / \Phi\left(\hat{\gamma}^{\prime} w_{i}\right)$ e $\hat{\delta}_{i}=\hat{\lambda}_{i}\left(\hat{\lambda}_{i}-\hat{\gamma}^{\prime} w_{i}\right)$. Em seguida, são obtidas as estimativas consistentes dos parâmetros $\beta$, utilizando o método de mínimos quadrados de $y$ em função de $x$ e $\hat{\lambda}$.

A Tabela 10 apresenta os resultados dos coeficientes estimados para as equações de salários de pais e de mães utilizando o procedimento de Heckman.

Tabela 10. Equações de salários estimadas para pais e mães, utilizando o procedimento de Heckman.

\begin{tabular}{lcc}
\hline Ln dos rendimentos & Pais & Mães \\
\hline Constante & $4,608197 * * *$ & $3,767040 * * *$ \\
Escolaridade & $0,026803 * * *$ & $0,035874 * * *$ \\
Idade & 0,010922 & $0,027601 * * *$ \\
Idade ao quadrado & $-0,000002$ & $-0,000277 * *$ \\
Urbano & $0,260754 * * *$ & $0,281341 * * *$ \\
Norte & $0,211606 * * *$ & $0,231787 * * *$ \\
Sul & $0,258053 * * *$ & $0,284735 * * *$ \\
Centro Oeste & $0,328937 * * *$ & $0,267813 * * *$ \\
Sudeste & $0,283711 * * *$ & $0,279701 * * *$ \\
Lambda & $-2,753653 * * *$ & $-0,409260 * * *$ \\
\hline$* * *$ denota significância ao nível de $1 \%$ & &
\end{tabular}

